\title{
Petrological and experimental evidence for differentiation of water-rich magmas beneath St. Kitts, Lesser Antilles
}

\author{
Elena Melekhova $^{1} \cdot$ Jon Blundy $^{1} \cdot$ Rita Martin $^{1} \cdot$ Richard Arculus $^{2} \cdot$ \\ Michel Pichavant ${ }^{3}$
}

Received: 1 June 2017 / Accepted: 20 October 2017 / Published online: 10 November 2017

(C) The Author(s) 2017. This article is an open access publication

\begin{abstract}
St. Kitts lies in the northern Lesser Antilles, a subduction-related intraoceanic volcanic arc known for its magmatic diversity and unusually abundant cognate xenoliths. We combine the geochemistry of xenoliths, melt inclusions and lavas with high pressure-temperature experiments to explore magma differentiation processes beneath St. Kitts. Lavas range from basalt to rhyolite, with predominant andesites and basaltic andesites. Xenoliths, dominated by calcic plagioclase and amphibole, typically in reaction relationship with pyroxenes and olivine, can be divided into plutonic and cumulate varieties based on mineral textures and compositions. Cumulate varieties, formed primarily by the accumulation of liquidus phases, comprise ensembles that represent instantaneous solid compositions from one or more magma batches; plutonic varieties have mineralogy and textures consistent with protracted solidification of magmatic mush. Mineral chemistry in lavas and xenoliths is subtly different. For example, plagioclase with unusually high anorthite content $\left(\mathrm{An}_{\leq 100}\right)$ occurs in some plutonic xenoliths, whereas the most calcic plagioclase in
\end{abstract}

Communicated by Othmar Müntener.

Electronic supplementary material The online version of this article (https://doi.org/10.1007/s00410-017-1416-3) contains supplementary material, which is available to authorized users.

Elena Melekhova

lena.melekhova@bristol.ac.uk

1 School of Earth Sciences, University of Bristol, Wills Memorial Building, Bristol BS8 1RJ, UK

2 Research School of Earth Sciences, Australian National University, Canberra, ACT 2601, Australia

3 CNRS/INSU, ISTO, BRGM, UMR 7327, Université d'Orléans, 1A Rue de la Ferollerie, 45071 Orléans, France cumulate xenoliths and lavas are $\mathrm{An}_{97}$ and $\mathrm{An}_{95}$, respectively. Fluid-saturated, equilibrium crystallisation experiments were performed on a St. Kitts basaltic andesite, with three different fluid compositions $\left(X_{2} \mathrm{O}=1.0,0.66\right.$ and 0.33 ) at $2.4 \mathrm{kbar}, 950-1025{ }^{\circ} \mathrm{C}$, and $f \mathrm{O}_{2}=\mathrm{NNO}-0.6$ to $\mathrm{NNO}+1.2 \log$ units. Experiments reproduce lava liquid lines of descent and many xenolith assemblages, but fail to match xenolith and lava phenocryst mineral compositions, notably the very An-rich plagioclase. The strong positive correlation between experimentally determined plagioclase-melt $\mathrm{Kd}_{\mathrm{Ca}-\mathrm{Na}}$ and dissolved $\mathrm{H}_{2} \mathrm{O}$ in the melt, together with the occurrence of Al-rich mafic lavas, suggests that parental magmas were water-rich $\left(>9 \mathrm{wt} \% \mathrm{H}_{2} \mathrm{O}\right)$ basaltic andesites that crystallised over a wide pressure range (1.5-6 kbar). Comparison of experimental and natural (lava, xenolith) mafic mineral composition reveals that whereas olivine in lavas is predominantly primocrysts precipitated at low-pressure, pyroxenes and spinel are predominantly xenocrysts formed by disaggregation of plutonic mushes. Overall, St. Kitts xenoliths and lavas testify to mid-crustal differentiation of low-MgO basalt and basaltic andesite magmas within a trans-crustal, magmatic mush system. Lower crustal ultramafic cumulates that relate parental low$\mathrm{MgO}$ basalts to primary, mantle -derived melts are absent on St. Kitts.

Keywords Xenolith Cumulates $\cdot$ High-An plagioclase . Differentiation of basaltic andesite $\cdot$ Experiments · Magma mush'

\section{Introduction}

Arc magmatism above subduction zones involves chemical differentiation of mantle-derived basaltic magmas 
to intermediate and silicic compositions. Differentiation involves a combination of fractional crystallisation, and crustal melting and assimilation, the relative importance of which varies within and between arcs. Erupted arc magmas represent the integration of differentiation processes that begin with melting in the mantle wedge and, consequently, provide information only on an end product. A complementary approach is to focus on xenoliths brought to the surface during eruptions (e.g. Baker 1968; Arculus and Wills 1980; Conrad et al. 1983; Kay and Kay 1985; Hickey-Vargas et al. 1995; Ducea and Saleeby 1998; Costa et al. 2002; Dungan and Davidson 2004; Mcleod et al. 2013; Yamamoto et al. 2013; Smith 2014; Haase et al. 2014; Price et al. 2016). Such xenoliths may include cumulate residues from crystal fractionation, plutonic equivalents of erupted magma, or fragments of crustal rocks. Here we focus on xenoliths found on the Lesser Antilles island of St. Kitts. By integrating insights from xenoliths with the geochemical record of volcanic rocks and with high pressure-temperature phase equilibrium experiments, we develop an image of the subvolcanic magma plumbing system beneath St. Kitts.

\section{Geological setting and previous work}

St. Kitts lies within the central Lesser Antilles volcanic arc formed by westwards subduction of the Atlantic oceanic lithosphere. The geology of the island is described in some detail by Baker $(1968,1984)$ and Toothill et al. (2007). In brief, St. Kitts comprises four volcanic centers, the most prominent of which is Mt. Liamuiga (formerly Mt. Misery) rising $1157 \mathrm{~m}$ above sea-level. The oldest volcanic rocks of the island have been dated at $\sim 1-2 \mathrm{Ma}$ (Maury and Westercamp 1990), although radiometric ages are rather sparse. The last dated eruption, from Mt. Liamuiga, was 1800 years BP and there have been no documented eruptions since settlement in 1624. Erupted rock types range from basalt to rhyolite, with basaltic andesites and andesites dominant (Baker 1984), both as pyroclastic deposits and as lavas. Magnesium-rich basalt ( $\leq 7 \mathrm{wt} \% \mathrm{MgO}$ ) lavas, with phenocrysts of olivine, clinopyroxene, and plagioclase, occur on the north-east coast at Black Rocks. These are putative parental magmas (Turner et al. 1996; Toothill et al. 2007), although their $\mathrm{Mg} \#($ molar $\mathrm{Mg} /[\mathrm{Mg}+\mathrm{Fe}]) \leq 0.64$ are too low to have been derived directly from mantle wedge peridotite (Toothill et al. 2007). Isotopic data indicate that differentiation was dominated by fractional crystallisation processes with negligible assimilation of older sialic crust and limited $(<10 \%)$ assimilation of biogenic sediments (Toothill et al. 2007). Consequently, St. Kitts represents one extreme of arc magmatic differentiation in which the role of crustal melting is minimal.

In keeping with other Lesser Antilles volcanic islands (Arculus and Wills 1980), St. Kitts yields a large number of magmatic (or cognate) xenoliths, entrained in pyroclastic rocks. Xenoliths from St. Kitts were first described by Fels (1903) and Earle (1925). Baker (1968) notes that St. Kitts xenoliths occur originally in pyroclastic rocks, but are also preferentially weathered out and accumulate in river drainage channels (or "ghuts"). Although such samples lack geological context, in terms of their parent eruptions, their accumulation provides a means to sample a great variety of textural and chemical types. Xenoliths, with or without fragments of host lava, occur as rounded clasts ranging in size from few $\mathrm{cm}$ to a half a metre.

Given the relative youth of the island, all xenoliths can be ascribed to the magmatic activity that constructed St. Kitts and are, therefore, representative of the sub-volcanic arc crust. Baker (1968) presents petrographic data for thirteen xenoliths from Harris, Godwin, Saddler's and Pogson's Ghuts. A further thirteen xenoliths were described in detail by Arculus and Wills (1980). St. Kitts xenoliths exhibit great petrological diversity, with assemblages including: (1) olivine + plagioclase; (2) olivine + plagioclase + orthopyroxene + magnetite; (3) olivine + plagioclase + orthopyroxene + clinopyroxene + magnetite + amphibole; and (4) plagioclase + orthopyroxene + clinopyroxene + magnetite + amphibole + quartz + biotite. The combination of relatively abundant orthopyroxene and very calcic plagioclase (> $94 \mathrm{~mol} \%$ anorthite) distinguishes St. Kitts xenoliths from other Lesser Antilles islands (Baker 1968; Lewis 1973; Arculus and Wills 1980; Kiddle et al. 2010; Tollan et al. 2012; Stamper et al. 2014; Cooper et al. 2017).

This study is based on a total of $35 \mathrm{St}$. Kitts xenoliths collected during a field campaign in 2009 and augmented by five xenoliths from the collection at Durham University. Petrological data from St. Kitts xenoliths are studied in conjunction with published whole-rock geochemical analyses of St. Kitts lavas (Baker 1984; Turner et al. 1996; Toothill et al. 2007) and new and published experimental petrology data.

\section{Methods}

\section{Analytical}

Initial petrographic analyses were carried out on forty St. Kitts xenoliths. These were subsequently divided into thirteen representative types based on mineral assemblages and textures (Table 1). Xenoliths were classified using the British Geological Society Rock Classification Scheme (1999), and Streckeisen (1976). Modal abundances of the major mineral phases for each of the 13 representative xenoliths were obtained by point counting (Table 1, Fig. 1) using a Pelcon Automatic point counter 1.8 coupled to an optical microscope. Between 1250 and 1750 points were counted for each xenolith. Volume modes were converted into mass 
Table 1 Classification, modes, and brief descriptions of xenolith samples

\begin{tabular}{|c|c|c|c|}
\hline Sample & Rock type & Mineral modes (wt \%) & Description \\
\hline \multicolumn{4}{|c|}{ Cumulates } \\
\hline $\mathrm{KS}-8$ & ol-amph-gabbro & $\mathrm{ol}(5), \operatorname{amph}(37), \mathrm{pl}(58)$ & $\begin{array}{l}\text { Coarse-grained; euhedral, unzoned, incl- and MI-rich } \\
\text { pl } \leq 20 \mathrm{~mm} \text {; enclosed by subhedral amph; interstitial } \\
\text { scoria }\end{array}$ \\
\hline KS-21 & ol-amph-gabbro & ol (3) amph (60), pl (35), mag (2), sulf (tr) & $\begin{array}{l}\text { Very coarse-grained; large poikilitic amph; unzoned } \\
\text { euhedral pl with MIs }\end{array}$ \\
\hline KS-15 & ol-amph-gabbro & ol (2), amph (27), pl (60), mag (12), sulf (tr) & $\begin{array}{l}\text { Coarse-grained; mag } \leq 20 \mathrm{~mm} \text {, some with sulf inclu- } \\
\text { sions; amph and } \mathrm{pl} \leq 30 \mathrm{~mm} \text {; iddingsitised ol; amph } \\
\text { and pl rich in MIs }\end{array}$ \\
\hline KS-7 & ol-amph-gabbro & ol (1), cpx (1), amph (31), pl (59), mag (8), sulf (tr) & $\begin{array}{l}\text { Coarse-grained; large poikilitic amph; incl-rich but } \\
\text { unzoned } \mathrm{pl} \text {; ol surrounded by amph; cpx with Mis; } \\
\text { sulf in } \mathrm{mt} \text { and as separate grains, interstitial scoria }\end{array}$ \\
\hline KS-12 & ol-amph-gabbronorite & $\begin{array}{l}\text { ol (2), cpx (9), opx (6), amph (21), pl (58), mag (3), } \\
\text { sulf (tr), bio (tr) }\end{array}$ & $\begin{array}{l}\text { Fine-to-coarse-grained; Two generations of amph } \\
\text { some poikilitic enclosing cpx and ol, others euhedral } \\
\text { enclosed by pl; MIs in opx }\end{array}$ \\
\hline KS-11 & ol-norite & ol (5), opx (12), pl (77), mag (6), sulf (tr) & $\begin{array}{l}\text { Coarse-grained; equilibrated (120o intersections); } \\
\text { unzoned MI-bearing pl and opx }\end{array}$ \\
\hline KS-24 & amph-gabbro & cpx (1), amph (30), pl (61), mag (8), qz (tr), sulf (tr) & $\begin{array}{l}\text { Layered fine-med-coarse-grained; trace of cpx and sulf; } \\
\text { unzoned but inclusion and MI-rich pl }\end{array}$ \\
\hline KS-17 & ol-amph-gabbro & ol, cpx, amph, pl, mag, sulf (tr) & $\begin{array}{l}\text { Medium-grained, well equlibrated; } \mathrm{MI} \text { in ol, cpx and } \\
\text { amph; incl of mag in plag }\end{array}$ \\
\hline \multicolumn{4}{|c|}{ Plutonic rocks } \\
\hline KS-3 & ol-gabbro & ol (2), cpx (18), opx (3), pl (73), mag + ilm (4) & $\begin{array}{l}\text { Lava with enclosed medium-grained plutonic fragment; } \\
\text { normally-zoned px; incl-rich, oscillatory-zoned pl }\end{array}$ \\
\hline KS-31 & ol-amph-gabbro & $\begin{array}{l}\text { ol (2), cpx (5), opx (3), amph (30), pl (58), mag + ilm } \\
\quad(2)\end{array}$ & $\begin{array}{l}\text { Fine-medium-grained; Two types of cpx: cpx with } \\
\text { amph halo, sometime enclosing ol, and cpx in resorp- } \\
\text { tion rims of amph; some ol with mag-rich symplectite } \\
\text { rim; incl-rich pl }\end{array}$ \\
\hline KS-22 & ol-amph-gabbro & $\begin{array}{l}\text { ol (2), cpx (14), opx (1), amph (10), pl (70), } \\
\text { mag + ilm (3), sulf (tr) }\end{array}$ & $\begin{array}{l}\text { Fine-medium-grained; trace opx; ol and cpx sur- } \\
\text { rounded by amph; incl-rich and slightly zoned pl; } \\
\text { mag and sulf usually together }\end{array}$ \\
\hline KS-16 & amph-gabbro & $\begin{array}{l}\text { opx (3), amph (20), pl (74), mag + ilm (3), sulf (tr), } \\
\text { ap (tr) }\end{array}$ & $\begin{array}{l}\text { Medium-coarse-grained; bimodal pl population: } \\
\text { anorthite and labradorite; pl has normal and reverse } \\
\text { zoning; hbl oikocrysts }\end{array}$ \\
\hline $\mathrm{KS}-4$ & amph-gabbro & $\begin{array}{l}\text { cpx (1), opx (4), amph (17), pl (74), mag + ilm (3), } \\
\text { qz (0.6) }\end{array}$ & $\begin{array}{l}\text { Fine-grained; px rimmed by amph; zoned and incl-rich } \\
\text { pl }\end{array}$ \\
\hline KS-6 & amph-gabbro & opx (2), amph (28), pl (66), mag + ilm (4) & $\begin{array}{l}\text { Coarse-grained; euhedral to subhedral amph; } \mathrm{pl} \text { has } \\
\text { patchy and normal zoning zoning; MI in pl and amph }\end{array}$ \\
\hline
\end{tabular}

ol olivine, $p l$ plagioclase, amph amphibole, $c p x$ clinopyroxene, opx orthopyroxene, sulf Sulphide, $q z$ quartz, mag magnetite, ilm ilmenite, bio biotite, ap apatite, $M I$ melt inclusion, incl inclusion

modes using mineral densities, modified where appropriate for solid solution (as determined from mineral analyses), from Deer et al. (1992).

Thin sections were imaged by Hitachi S-3500N scanning electron microscope (SEM) using backscattered electrons (BSE) obtained at 15 or $20 \mathrm{kV}$. Major element analyses were performed on a five-spectrometer Cameca SX-100 electron microprobe, calibrated on a variety of oxide and mineral standards. Analytical conditions were 15 or $20 \mathrm{kV}$ acceleration voltage, and $10 \mathrm{nA}$ focused beam for crystals. To minimize alkali loss during analyses of hydrous melt inclusions (MI) and interstitial glass the beam current was dropped to $4 \mathrm{nA}$ and beam diameter increased to $10 \mu \mathrm{m}$. Ferric iron contents were estimated using the stoichiometric methods of Droop (1987) for spinel, Wood and Banno (1973) for clinopyroxene, and Holland and Blundy (1994) for amphibole.

Volatile contents and some trace elements in glassy melt inclusions within plagioclase, orthopyroxene, hornblende, magnetite and ilmenite crystals, were analysed by secondary ion mass spectrometry (SIMS) at the NERC ion-microprobe facility, University of Edinburgh, using a Cameca IMS-4f instrument. Analyses were performed with a nominal $10 \mathrm{kV}$ primary beam of $\mathrm{O}^{-}$ions and $5 \mathrm{nA}$ beam current focused to a $\sim 20 \mu$ m diameter spot at the sample surface. $\mathrm{H}_{2} \mathrm{O}$ was measured as ${ }^{1} \mathrm{H}^{+}$secondary ions at a nominal mass resolving power $(M / \Delta M)$ of 300 and $25 \mu \mathrm{m}$ image field. Some trace 
(a)

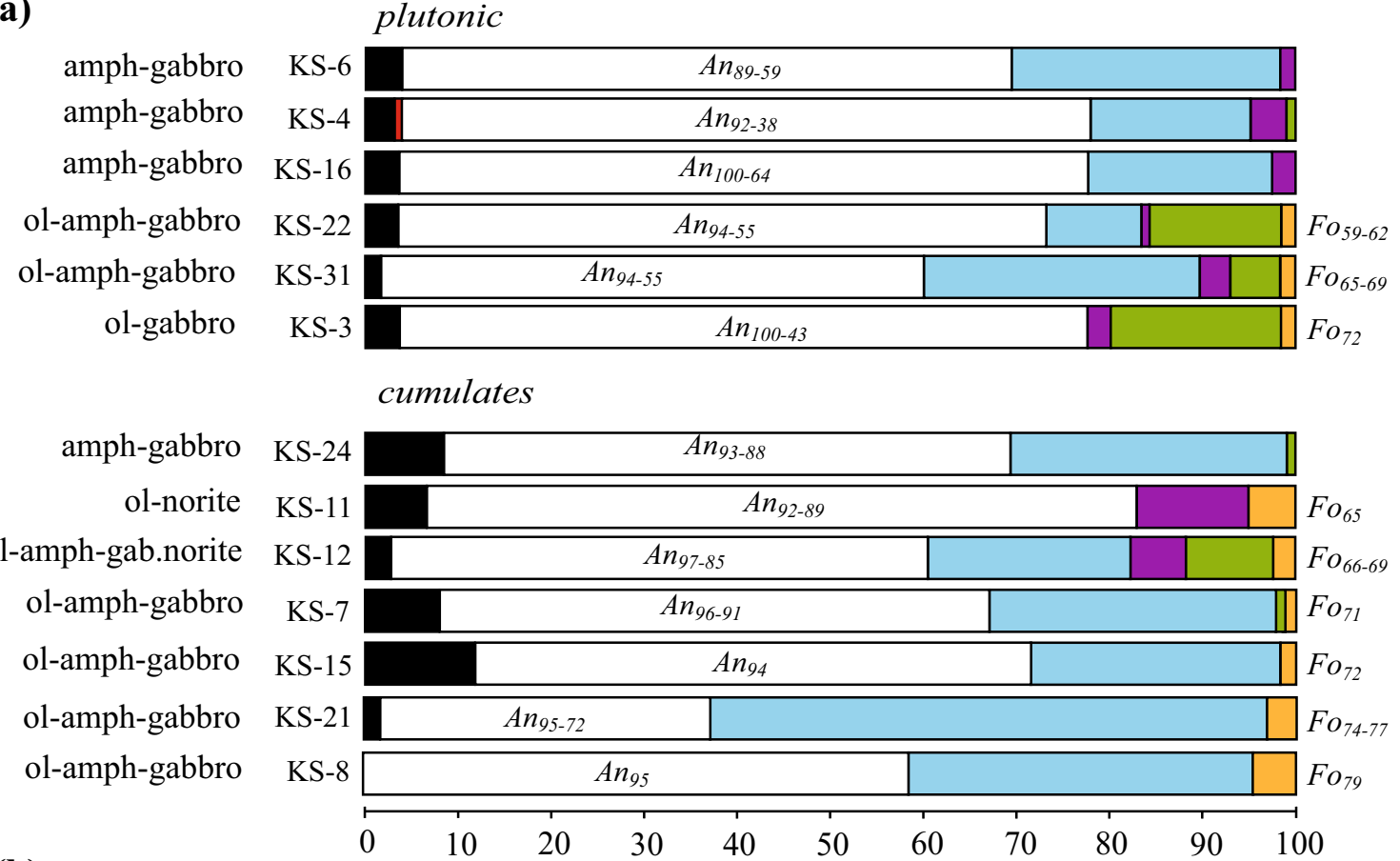

(b)

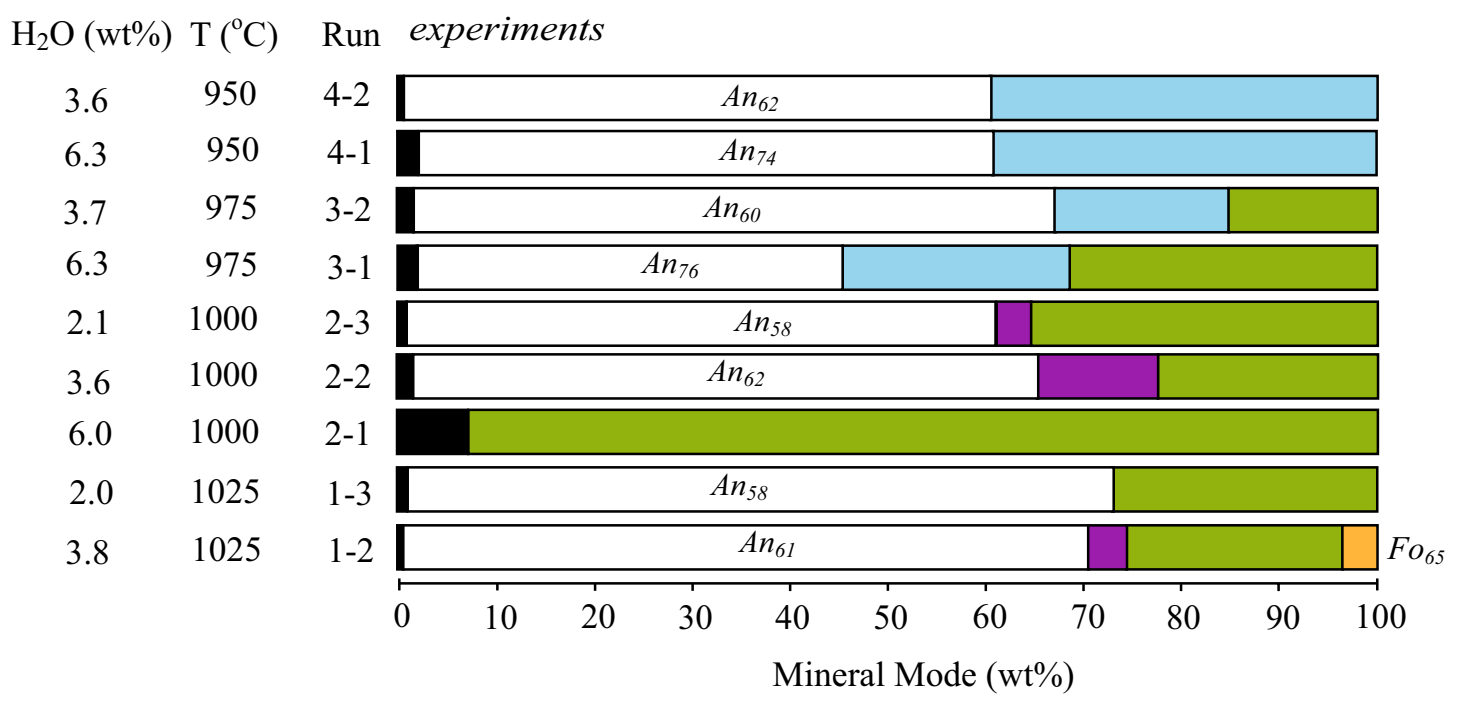

$\square$ ol $\square$ cpx $\square$ opx $\square$ hbl $\square$ plag $\square$ qz $\square$ oxides

Fig. 1 a Modal proportions, by mass, of minerals in St. Kitts cumulate xenoliths using the classification in Table 1. Cumulates are listed (from bottom to the top) in order of decreasing Fo content of olivine,

elements were analysed simultaneously with ${ }^{1} \mathrm{H}^{+}$. For $\mathrm{CO}_{2}$, measured as ${ }^{12} \mathrm{C}^{+}$, a higher $M / \Delta M=800-1000$ was applied to resolve ${ }^{24} \mathrm{Mg}^{2+}$ from ${ }^{12} \mathrm{C}^{+}$, and a $20 \mu \mathrm{m}$ image field used. Positive secondary ions were extracted at $4.5 \mathrm{kV}$ with an offset of $50 \mathrm{~V}$ (for $\mathrm{C}$ ) and $75 \mathrm{~V}$ (for $\mathrm{H}$ ) to reduce transmission of molecular ions. Pumping to a vacuum of $\leq 10^{-9}$ Torr minimized the background to $\sim 2$ counts per second followed by An of plagioclase. b Modal proportions of silicate and oxide minerals in experimental solid residues

for ${ }^{12} \mathrm{C}$ and $\sim 300 \mathrm{cps}$ for ${ }^{1} \mathrm{H}$. Minimum detection limits (calculated from 3 s.d. on backgrounds) were $\sim 11 \mathrm{ppm} \mathrm{CO}_{2}$ and $\sim 70 \mathrm{ppm} \mathrm{H}_{2} \mathrm{O}$. We calibrated $\mathrm{H}_{2} \mathrm{O}$ and $\mathrm{CO}_{2}$ against synthetic basaltic glass standards (Lesne et al. 2011) containing 0 to $3 \mathrm{wt} \% \mathrm{H}_{2} \mathrm{O}$ and $0-2000 \mathrm{ppm} \mathrm{CO}_{2}$. Working curves of ${ }^{1} \mathrm{H} /{ }^{30} \mathrm{Si}$ vs $\mathrm{H}_{2} \mathrm{O}$ and ${ }^{12} \mathrm{C} /{ }^{30} \mathrm{Si}$ vs $\mathrm{CO}_{2}$ gave straight lines with $R^{2} \geq 0.99$. 


\section{Experiments}

The objective of the high pressure and temperature experiments was to investigate the differentiation conditions that led to the observed geochemical diversity in lavas and xenoliths. The most magnesian (primitive) basalts on St. Kitts have up to $7 \mathrm{wt} \% \mathrm{MgO}$ and phenocrysts of plagioclase, olivine $\left(\mathrm{Fo}_{<70}\right)$ and clinopyroxene (Toothill et al. 2007). Fractional crystallisation of these phases from such basalts can produce St. Kitts' lower $\mathrm{MgO}$ basalts and basaltic andesites (Toothill et al. 2007). Orthopyroxene and Fe-Ti oxide phenocrysts do not appear until the host lava is basaltic andesite with $\sim 4 \mathrm{wt} \% \mathrm{MgO}$. Given the presence of orthopyroxene in many St. Kitts xenoliths, we chose an experimental starting material with slightly more evolved composition than the most $\mathrm{MgO}$-rich St. Kitts basalt. In this way, we increased the likelihood of attaining multiple saturation with a variety of minerals observed in xenoliths, and generating sufficiently large pools of experimental melt to analyse by electron microprobe. Conversely, the abundance of liquidus olivine was reduced.

The selected starting composition (K56) is basaltic andesite lava from Black Rocks with microphenocrysts of plagioclase (28 vol\%), olivine (1.5 vol\%), oxides ( 1 vol\%) and traces of clinopyroxene and orthopyroxene (Baker 1984). The sample KS_BR1 used in this study is identical to K56 and was kindly provided by Rob Watts. The major element compositions of K56 and KS_BRl are presented in Table 2. K56 is chemically similar to a basaltic andesite from Mont Pelée, Martinique (031-22b1; Table 2) studied experimentally by Pichavant et al. (2002a, b), allowing the two sets of experimental results to be considered together.

Powdered KS_BRl was dried at $100{ }^{\circ} \mathrm{C}$ for $4 \mathrm{~h}$ and then fused in a 1 atm gas mixing furnace at $f \mathrm{O}_{2}=\mathrm{NNO}+1 \log$ unit in a platinum crucible. Two cycles of melting ( 2 and $4 \mathrm{~h}$ duration) and grinding were carried out to produce a chemically homogeneous glass, as determined by electron microprobe (Table 2). Gold capsules of 2.5-3.0 mm OD were filled with the crushed glass $(15-20 \mu \mathrm{m}$ grain size), to which volatiles were added as $\mathrm{H}_{2} \mathrm{O} \pm \mathrm{Ag}_{2} \mathrm{C}_{2} \mathrm{O}_{4}$ to create three different starting materials with the following initial molar fractions of $\mathrm{H}_{2} \mathrm{O} /\left(\mathrm{H}_{2} \mathrm{O}+\mathrm{CO}_{2}\right): X \mathrm{H}_{2} \mathrm{O}=1,0.66$ and 0.33 . The total added volatile content in each experiment was $9.5-10 \mathrm{wt} \%$.

Experiments were carried out at $2.4 \mathrm{kbar}$ in internally heated vessels at Université d'Orleans pressurized with Ar- $\mathrm{H}_{2}$ mixtures (Pichavant and Macdonald 2007). Temperature was measured with two S-type thermocouples with uncertainty $\pm 5{ }^{\circ} \mathrm{C}$. The thermal gradient for a $3 \mathrm{~cm}$-long capsule was $<5^{\circ} \mathrm{C}$. Run duration, following Pichavant et al. (2002a, b), was between 22 and 6 h. Three experimental capsules, plus redox sensor capsule, were placed together in a thin alumina tube held by a $\mathrm{Pt}$ wire at the furnace hot spot.
Table 2 Experimental starting composition

\begin{tabular}{llll}
\hline & K56 $^{\mathrm{a}}$ & KS_BRl $^{\mathrm{b}}$ & $031-22 \mathrm{~b}^{\mathrm{c}}$ \\
\hline $\mathrm{SiO} 2$ & 53.77 & 54.64 & 53.00 \\
$\mathrm{TiO} 2$ & 0.96 & 0.95 & 0.78 \\
$\mathrm{Al2O} 3$ & 18.24 & 18.35 & 19.00 \\
$\mathrm{Cr} 2 \mathrm{O} 3$ & 0.00 & 0.03 & - \\
$\mathrm{FeO} *$ & 9.18 & 8.63 & 8.85 \\
$\mathrm{MnO}$ & 0.22 & 0.25 & 0.17 \\
$\mathrm{MgO}$ & 3.82 & 3.94 & 4.24 \\
$\mathrm{CaO}$ & 8.68 & 8.55 & 9.60 \\
$\mathrm{Na} 2 \mathrm{O}$ & 3.56 & 3.54 & 2.79 \\
$\mathrm{~K} 2 \mathrm{O}$ & 0.44 & 0.49 & 0.67 \\
$\mathrm{P} 2 \mathrm{O} 5$ & 0.12 & 0.08 & 0.11 \\
$\mathrm{NiO}$ & 0.00 & 0.00 & - \\
$\mathrm{Total}$ & 98.99 & 99.44 & 99.78 \\
& $\mathrm{Mg \#} 43$ & $\mathrm{Mg \#} 45$ & $\mathrm{Mg} 46$ \\
\hline
\end{tabular}

$\mathrm{FeO} *$ is iron total

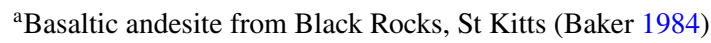

${ }^{\mathrm{b}}$ Basaltic andesite starting composition used in this study

${ }^{\mathrm{c}}$ Martinique basaltic andesite starting composition of Pichavant et al. (2002a, b)

The wire was fused electrically at the end of an experiment to achieve isobaric drop-quench at $\sim 100^{\circ} \mathrm{C} / \mathrm{s}$. Experiments were performed at a hydrogen fugacity $\left(\mathrm{H}_{2}\right)$ corresponding to $\mathrm{NNO}+1$. $f \mathrm{H}_{2}$ and $f \mathrm{O}_{2}$ are related via the dissociation of $\mathrm{H}_{2} \mathrm{O}$ :

$\mathrm{H}_{2} \mathrm{O}=\mathrm{H}_{2}+1 / 2 \mathrm{O}_{2}$.

An Ni-Pd $f \mathrm{O}_{2}$ sensor (e.g. Scaillet et al. 1995; Pichavant and Macdonald 2007) was used to measure $f \mathrm{O}_{2}$ during each run. The sensor was composed of two pellets of NiPd alloys plus Ni metal to give different initial Ni/Pd ratios. The pellets were loaded into a Pt capsule together with excess $\mathrm{H}_{2} \mathrm{O}$. The metal phase was analysed after the experiment to calculate $f \mathrm{O}_{2}$ of the sensor. For any individual charge that is $\mathrm{H}_{2} \mathrm{O}$-undersaturated $\left(a \mathrm{H}_{2} \mathrm{O}<1\right) f \mathrm{O}_{2}$ differs from that of the sensor by $2 \log a \mathrm{H}_{2} \mathrm{O}$, according to Eq. (1). We calculated $a \mathrm{H}_{2} \mathrm{O}$ for each charge using the method of Burnham (1979) at the measured (or estimated) $\mathrm{H}_{2} \mathrm{O}$ content of the glass (see below). Experimental $\mathrm{fO}_{2}$ was then calculated from $a \mathrm{H}_{2} \mathrm{O}$ and $f \mathrm{H}_{2}$.

Quenched experimental charges were imaged by SEM and analysed for major elements by Cameca SX100 and JEOL JXA8530F electron microprobes. Larger glass pools and metallic sensors were analysed on the SX100, using the same analytical procedure as for natural samples. Run product crystals and smaller glass pools were analysed on the JXA8530F. Typical analytical conditions for minerals were $10 \mathrm{kV}, 10 \mathrm{nA}$ and $100 \mathrm{~nm}$ beam size; for glasses $10 \mathrm{kV}$, $2 \mathrm{nA}$ and $10 \mu \mathrm{m}$ beam size. In experiments with $a \mathrm{H} 2 \mathrm{O}<1$ 
glass pools were not big enough to analyse with a defocused beam and beam size was reduced to $4 \mu \mathrm{m}$; for some glasses (Runs 3-3 and 4-2) we were obliged to use a focused beam, leading to significant alkali loss $(<37 \%$ relative, Table 3$)$. Modal proportions of phases were obtained by mass balance calculations and presented in Table 3.

\section{Results}

\section{Petrography}

Based on petrographic observations of 40 thin sections (Table A3 Supplementary) we subdivided the xenoliths into cumulates, with relatively high variance mineral assemblages that represent instantaneous solid compositions (Morse 1976), and plutonics, whose texture and composition is consistent with complete solidification of an aliquot of crystal-rich magma during cooling to the solidus [i.e. total solid composition of Morse (1976)]. This bipartite distinction is used throughout the paper. Note that the bulk compositions of cumulates are not equivalent to any magma type (Arculus and Wills 1980); their nomenclature follows Wager et al. (1960).

Xenolith mineralogy is dominated by calcic plagioclase and hornblende. Minor olivine ( $\leq 5 \mathrm{vol} \%$ ) is widespread, but is frequently observed enclosed by pyroxene and/or amphibole. An important feature of the St. Kitts xenoliths is the presence of two pyroxenes in more than half of the collected samples, although orthopyroxene is more common in plutonics than in cumulates. Oxide minerals occur in all samples with the exception of cumulate xenolith KS-8. Nearly half of the analysed xenoliths contain co-existing ilmenite and magnetite, although ilmenite is confined to plutonic varieties. Plutonic olivine-gabbro xenolith $\mathrm{KS}-3$ is unique: it has exsolved Fe-Ti oxide pairs, with single grains showing discrete ilmenite-magnetite lamellae. Rare biotite was found in a single plutonic xenolith (KS-14). Quartz was found in five plutonic samples, although it is not always easy to distinguish igneous quartz from xenocrystic/inherited quartz phenocrysts. Sulphide is a widespread accessory phase. Melt inclusions are common and were found in amphibole, orthopyroxene, plagioclase, and oxides.

The relative crystallisation order of plutonic and cumulate xenoliths, determined from textural observations, shows a consistent pattern. Olivine, when present, is always the first phase to crystallise, with the sole exception of an olivinenorite (KS-11) sample where magnetite precedes olivine. Elsewhere, magnetite is the next phase to crystallise and occurs throughout the crystallisation sequence of all xenoliths. The order of orthopyroxene and clinopyroxene appearance varies: they either co-crystallise or clinopyroxene precedes orthopyroxene, which may reflect slight differences in crystallisation temperature between the samples (e.g. Leuthold et al. 2014, Fig. 19). Unusually, in KS-3 clinopyroxene crystallises after orthopyroxene. Plagioclase never crystallises before pyroxenes and typically appears either prior to amphibole or co-crystallises with it. There are two xenoliths, KS-22 and KS-6, in which amphibole crystallised before plagioclase. Amphibole often demonstrates a two-stage crystallisation: early crystallisation alongside pyroxene or plagioclase, and late-stage, interstitial crystallisation. Where present, biotite, apatite and quartz are always last in the crystallisation sequence. Sulphide occurs only as inclusions in magnetite. Ilmenite in plutonic xenoliths cocrystallises with late-stage magnetite.

Plutonic and cumulate xenolith types display striking variation in modal proportion of minerals, textures and amount of interstitial glass. A key difference between the two types is the strong mineral zoning observed in plutonic xenoliths (Fig. 2e). Textures suggestive of mineral-mineral and mineral-melt reactions, such as symplectic and poikilitic textures, as well interstitial amphibole (Fig. 3e), are more common in plutonic xenoliths. In contrast, cumulate xenoliths are minimally zoned, with adcumulate textures and euhedral crystals (Figs. $2 \mathrm{f}$ and $3 \mathrm{a}$ ). Based on textural observations and modes, plutonic and cumulate xenoliths were subdivided into seven diagnostic rock types; note that amphibole gabbros and olivine-amphibole gabbros occur as both plutonic and cumulate xenolith types.

\section{Plutonic xenoliths}

Amphibole gabbros are hypidiomorphic granular (1-2 mm grain size) with fabrics that range from well-foliated to isotropic. Amphibole occurs as both subhedral and intergranular crystals. Subhedral crystals define the foliation where present (e.g. KS-6). Intergranular amphiboles contains inclusions of plagioclase in their cores and orthopyroxene in their rims. Oxides occur as inclusions in plagioclase and amphibole but also form intergranular crystals in some samples (KS-16) with inclusions of plagioclase, amphibole and Sulphide. There is widespread evidence of amphibole-pyroxene reaction. In some samples, amphibole rims contain abundant orthopyroxene inclusions; in others, amphibole forms reaction rims around orthopyroxene and clinopyroxene. Plagioclase is strongly zoned with both concentric and patchy variants. Large plagioclase grains commonly contain inclusions of amphibole. In some samples (KS-4, KS-16) plagioclase ( \pm orthopyroxene) forms a mortar texture composed of small, interlocking grains around larger crystals of amphibole and zoned plagioclase. Interstitial quartz may be associated with small plagioclase crystals. Melt inclusions are common.

Olivine amphibole gabbros are isotropic, hypidiomorphic granular, with grain size $\leq 0.7 \mathrm{~mm}$. Orthopyroxene 


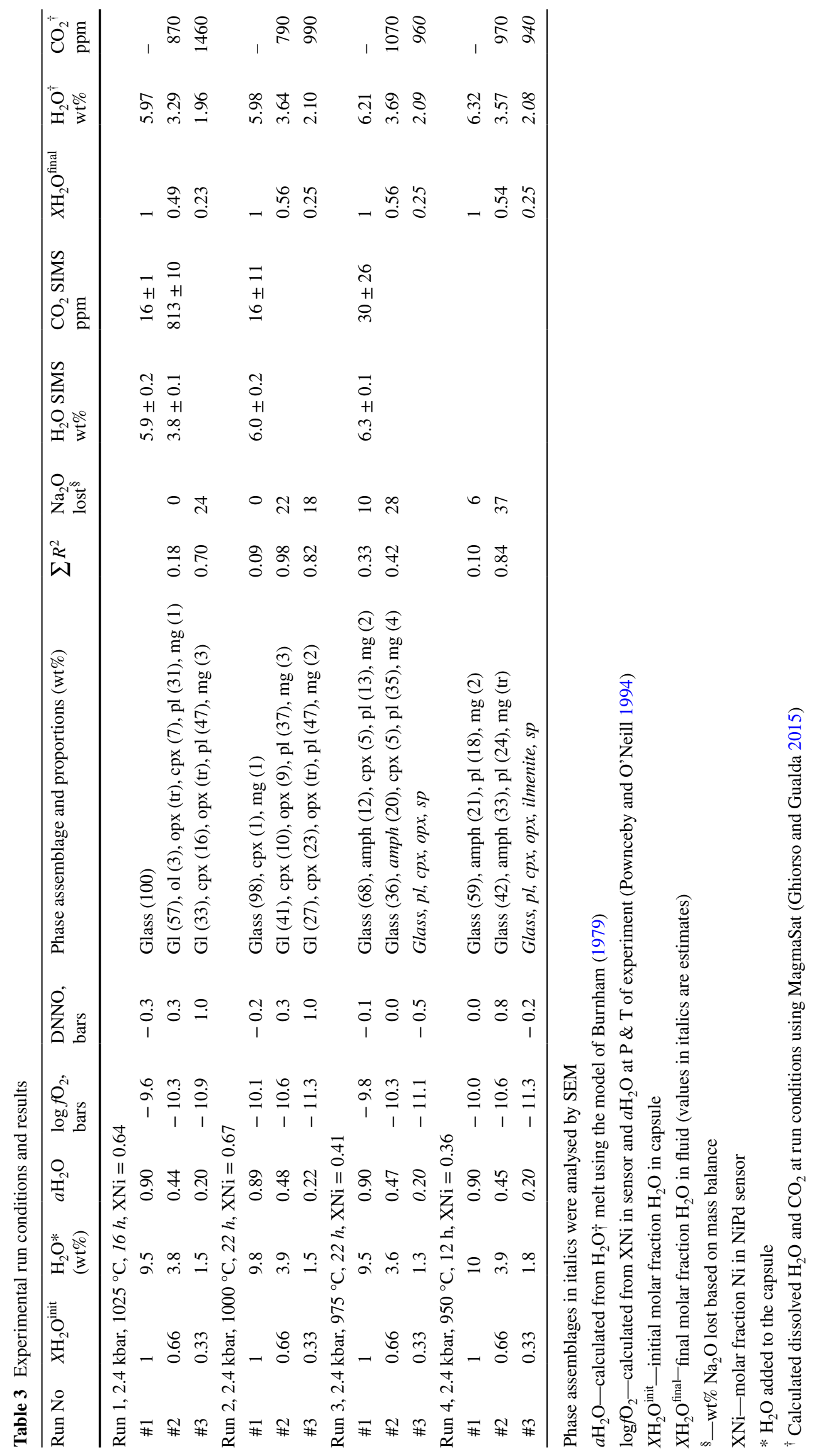



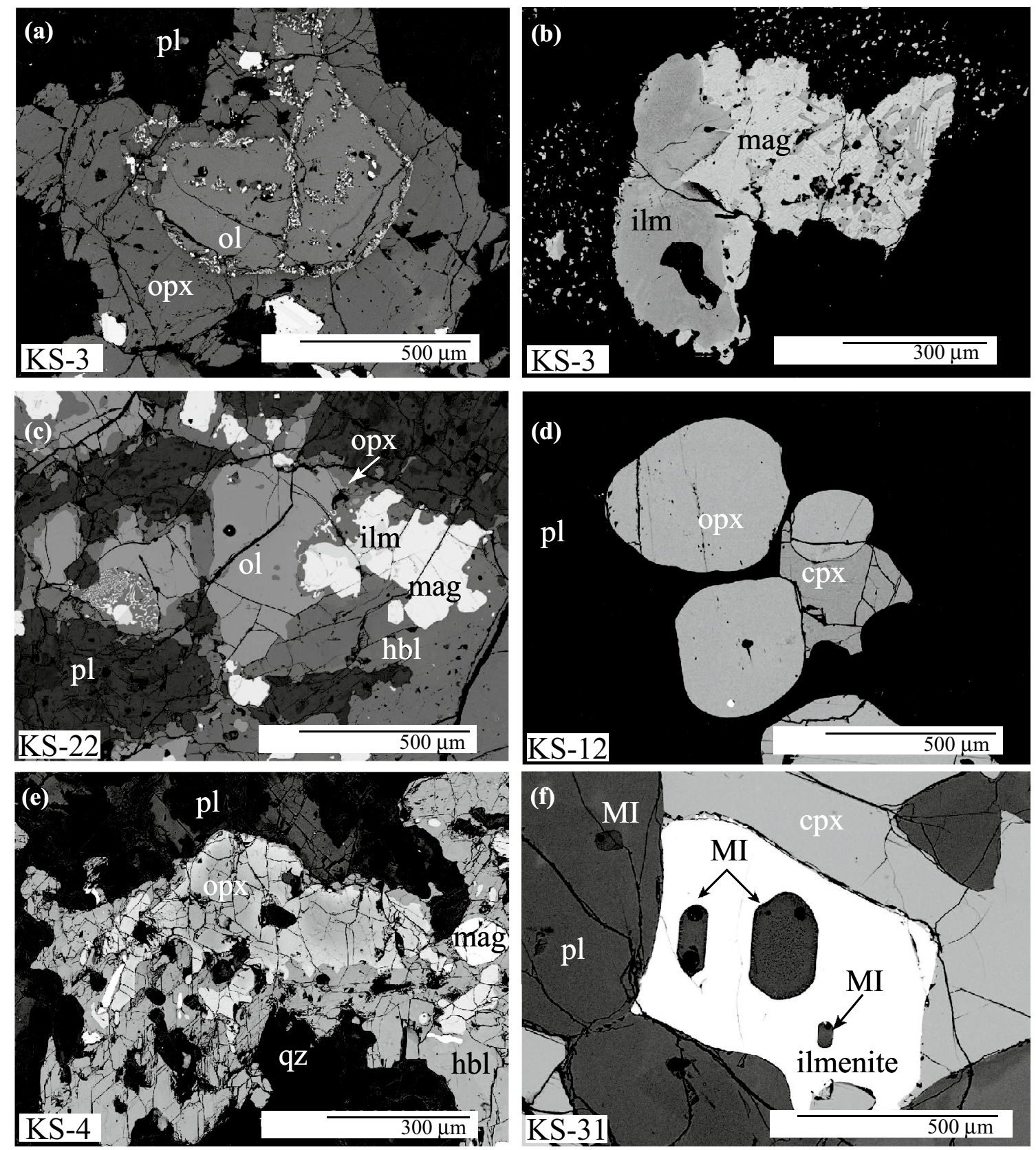

Fig. 2 BSE images of representative textures of xenoliths in Table 1. a Development of orthopyroxene-magnesioferrite oxidation symplectites within olivine grain (KS-3). b Magnetite-ilmenite exsolution (KS-3), c Olivine oikocrysts with orthopyroxene reaction rim

mainly forms reaction rims around olivine (Fig. 2c), typically as symplectite intergrowths with sub-micron opaque oxides. Amphibole reaction rims around clinopyroxene grains are common (Fig. 3b) and there is persuasive textural evidence for infiltration of amphibole-forming fluids along grain boundaries. Clinopyroxene often has sieve textures with abundant melt inclusions. Plagioclase is euhedral with normal zoning and often intergrown with amphibole
(KS-22). d Chadacrysts of orthopyroxene and clinopyroxene in plagioclase (KS-12). e Zoned orthopyroxene with MgO-rich core in poikilitic amphibole (KS-4). f Silica-rich melt inclusions in ilmenite (KS-31)

(Fig. 3c). Oxides are either anhedral inclusions in amphibole or form subhedral grains up to $0.8 \mathrm{~mm}$ (Fig. 2c). Ilmenite forms euhedral and anhedral grains, although it may also be interstitial. Small, glassy melt inclusions are ubiquitous and present in all minerals apart from olivine (Fig. 2f).

Olivine gabbro, as represented by KS-3, is a texturally complex, amphibole-free gabbro in contact with the host lava. Lava and xenolith display similar mineralogy. The 

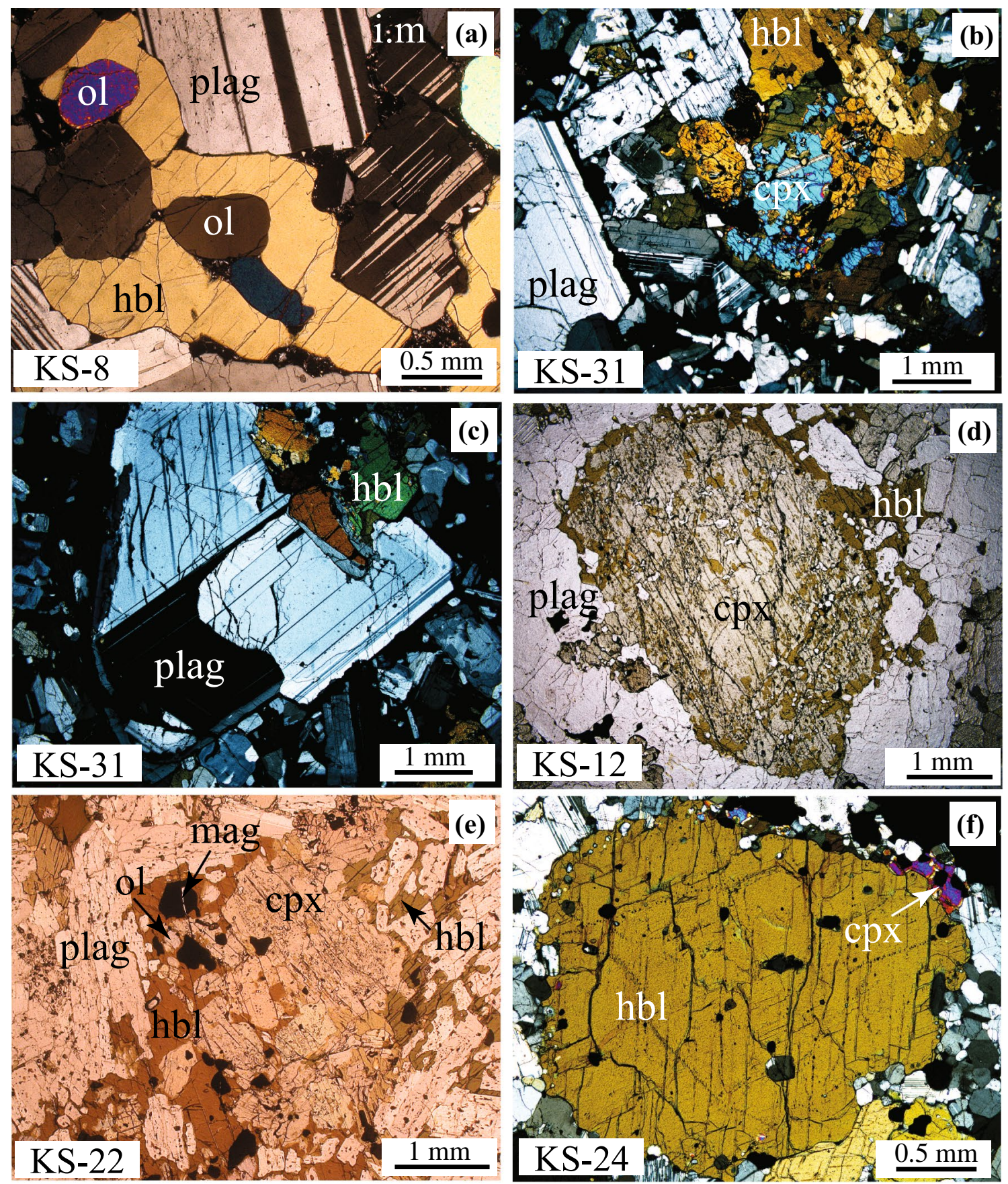

Fig. 3 Photomicrographs of representative xenolith textures (Table 1) in plane-polarised light (ppl) and cross-polarised light (xpl). a Olivine-amphibole gabbro (KS-8) showing orthocumulate texture (ppl). b, c Olivine-amphibole gabbronorite (KS-31) displaying several stages of amphibole crystallisation (xpl); b Clinopyroxene replacement by amphibole. Note clear clinopyroxene twinning and normal plagioclase zoning, $\mathbf{c}$ amphibole crystallisation prior to pla-

xenolith is crossed by fractures that are filled with microcrystals of oxides, anhedral orthopyroxene and plagioclase. In the xenolith part of the sample orthopyroxene forms reaction rims around partially iddingstised olivine (Fig. 2a), gioclase. Plagioclase shows resorption rim with melt inclusions. d Clinopyroxene grain exhibiting reaction to amphibole around the rim and interstitial amphibole (olivine-amphibole gabbronorite, KS-12) (ppl). e Similar texture in olivine-amphibole gabbro, KS-22 (ppl). f Clinopyroxene halo around phenocrystic amphibole (amphibole gabbro, KS-24) (xpl)

similar to those in olivine-amphibole gabbros. Clinopyroxene forms large subhedral phenocrysts $(\leq 2 \mathrm{~mm})$ with chadacrysts of magnetite. Some clinopyroxene is consumed in plagioclase-forming reactions. Plagioclase has strong 
normal zoning and often displays resorption rims containing small melt inclusions. Intergrown magnetite-ilmenite pairs show exsolution textures, suggestive of slow cooling (Fig. 2b).

\section{Cumulate xenoliths}

Amphibole gabbro is a well-equilibrated, layered adcumulate (KS-24, Fig. 3e) made up of two distinct layers with similar mineralogy. The coarse layer comprises euhedral amphibole $(\leq 3 \mathrm{~mm})$ and plagioclase $(\leq 2 \mathrm{~mm})$, and subhedral magnetite $(\leq 2 \mathrm{~mm})$. Large plagioclase grains are moderately zoned with one or more resorption rims containing abundant melt inclusions. The same minerals in the fine-grained layer have a mortar texture with grain size less than $0.3 \mathrm{~mm}$ around a few relict larger crystals with similar textures to the coarser layer, suggesting partial recrystallisation. Clinopyroxene forms small subhedral crystals with grain size $<0.2 \mathrm{~mm}$ and may also form halos around amphibole phenocrysts (e.g. KS-24; Fig. 3f).

Olivine amphibole gabbros can be subdivided texturally into mesocumulate and orthocumulate variants. Orthocumulates (KS-8, KS-15, KS-21) comprise large interlocking amphibole and large euhedral plagioclase $1-5 \mathrm{~mm}$ across. Olivine forms chadacrysts in amphibole (Fig. 3a) and is usually fresh apart from occasional iddingsitised grains in KS-15. Minerals in KS-8 and KS-15 are well equilibrated and rarely zoned. In KS-15 abundant magnetite forms large (1-3 mm) euhedral crystals, whereas KS-8 is distinguished by a lack of oxides. Medium-grained mesocumulate (KS-7) contains a small amphibole-rich, oxide-free xenolith enclave with mineral compositions similar to those of the host xenolith. Amphibole is poikilitic with chadacrysts of clinopyroxene, plagioclase, olivine and Al-rich magnetite. Magnetites range from large interstitial grains $(\leq 1.5 \mathrm{~mm}$ diameter) to small euhedral grains of $\leq 200 \mu \mathrm{m}$. Both variants contain pockets of interstitial microvesicular glass with microlites of clinopyroxene and plagioclase.

Olivine norite (KS-11) is dominated by sub-euhedral adcumulate plagioclase, magnetite and olivine with wellequilibrated $120^{\circ}$ grain boundaries. Poikilitic orthopyroxene is interstitial to plagioclase. There are additionally a few larger, anhedral orthopyroxenes with grain size $\leq 2 \mathrm{~mm}$. Olivine is iddingsite-free and contains glassy melt inclusions. Plagioclase twin planes have some slight flexure, suggestive of deformation.

Olivine amphibole gabbronorite (KS-12) is a texturally complex, transitional type of xenolith. It displays cumulative textures, but with strongly zoned, altered minerals and although grouped with cumulates equally be described as plutonic. Euhedral plagioclase and clinopyroxene are enveloped by poikilitic amphibole. Clinopyroxene grains commonly show reaction to amphibole along grain boundaries and fractures (Fig. 3d). Conversely, some anhedral amphiboles are mantled by complex coronas of intergrown clinopyroxene and plagioclase. Magnetite comprises anhedral blebs and subhedral crystals, both as inclusions in silicate phases and interstitial grains.

\section{Mineral and glass chemistry}

Representative mineral analyses are presented in Table A1 (Supplementary). For pyroxene and amphibole, $\mathrm{Mg \#}$ is expressed as $\mathrm{Mg} /\left(\mathrm{Mg}+\sum \mathrm{Fe}\right)$, where $\sum \mathrm{Fe}$ denotes total iron. Sulphides are present in many St. Kitts xenoliths, but are too small to be analysed. There is a relatively wide variation in amphibole and plagioclase mineral composition across the different xenolith types, but relatively limited chemical variation in pyroxenes, spinel and olivine.

Olivine is well preserved, rarely iddingsitized (the exception is KS-15), and ranges in composition from $\mathrm{Fo}_{77}$ to $\mathrm{Fo}_{59}$. Olivine from cumulate xenoliths tends to have higher Fo. The range in xenolith olivine is comparable to that of phenocrysts in St. Kitts lavas $\left(\mathrm{Fo}_{82-62} ;\right.$ Fig. 4). Individual xenolith grains are typically homogeneous $(\leq 4 \mathrm{~mol} \%$ variation in Fo). The greatest range is found in plutonic varieties (Figs. 1 and 4) where olivine is rimmed by orthopyroxene-oxide symplectites (Fig. 2a, c). Similar textures have been attributed by Johnston and Stout (1984) to oxidation of olivine.

In terms of minor components, $\mathrm{NiO}$ is consistently $\leq 0.07 \mathrm{wt} \% ; \mathrm{CaO}$ varies between 0.01 and $0.26 \mathrm{wt} \%$ (Fig. 4). There is no clear correlation between Fo and $\mathrm{CaO}$ or $\mathrm{NiO}$. The majority of olivine in cumulates overlap the $\mathrm{CaO}$ contents (0.15-0.22 wt\%) of phenocrysts in lavas (Fig. 4a). Conversely, the $\mathrm{CaO}$ contents in plutonic olivine tend to be much lower (0.01-0.11 wt\%), although there are two cumulate xenoliths, KS-12 and KS-11 with olivine $\mathrm{Fo}_{\leq 70}$ and $<0.10 \mathrm{wt} \% \mathrm{CaO}$, akin to plutonics (Fig. 4a). $\mathrm{MnO}$ ranges from 0.2 to $0.9 \mathrm{wt} \%$, and is negatively correlated with Fo (Fig. 4b). MnO contents in cumulate olivine are very similar to those from lavas, whereas plutonic olivine is displaced to higher $\mathrm{MnO}$. Unlike $\mathrm{CaO}, \mathrm{MnO}$ in $\mathrm{KS} 11$ and $\mathrm{KS} 12$ olivine does not deviate from the rest of the cumulates.

Oxides are ubiquitous in St. Kitts xenoliths, reaching 12 vol\% in KS-15. Only olivine-amphibole gabbro KS-8 is oxide-free. Oxides occur as inclusions in silicate phases, along grain boundaries, in interstitial melt and inside some melt inclusions. Individual euhedral oxides may be up to $1.5 \mathrm{~mm}$ (Fig. 2f).

The dominant oxide is magnetite-rich spinel, with relatively high $\mathrm{TiO}_{2}$ (4-14 wt\%) except for two Ti-poor spinel grains from KS3 (Table A2 Supplementary). $\mathrm{TiO}_{2}$-rich magnetite has also been reported from St. Kitts lavas (Toothill et al. 2007). $\mathrm{Cr}_{2} \mathrm{O}_{3}$ contents are consistently low ( $\leq 0.4 \mathrm{wt} \%$; Table A2 Supplementary). There are three distinct groupings of spinel composition in terms of $\mathrm{Al} \#\left(=\mathrm{Al} /\left(\mathrm{Al}+\mathrm{Fe}^{3+}\right)\right)$ 

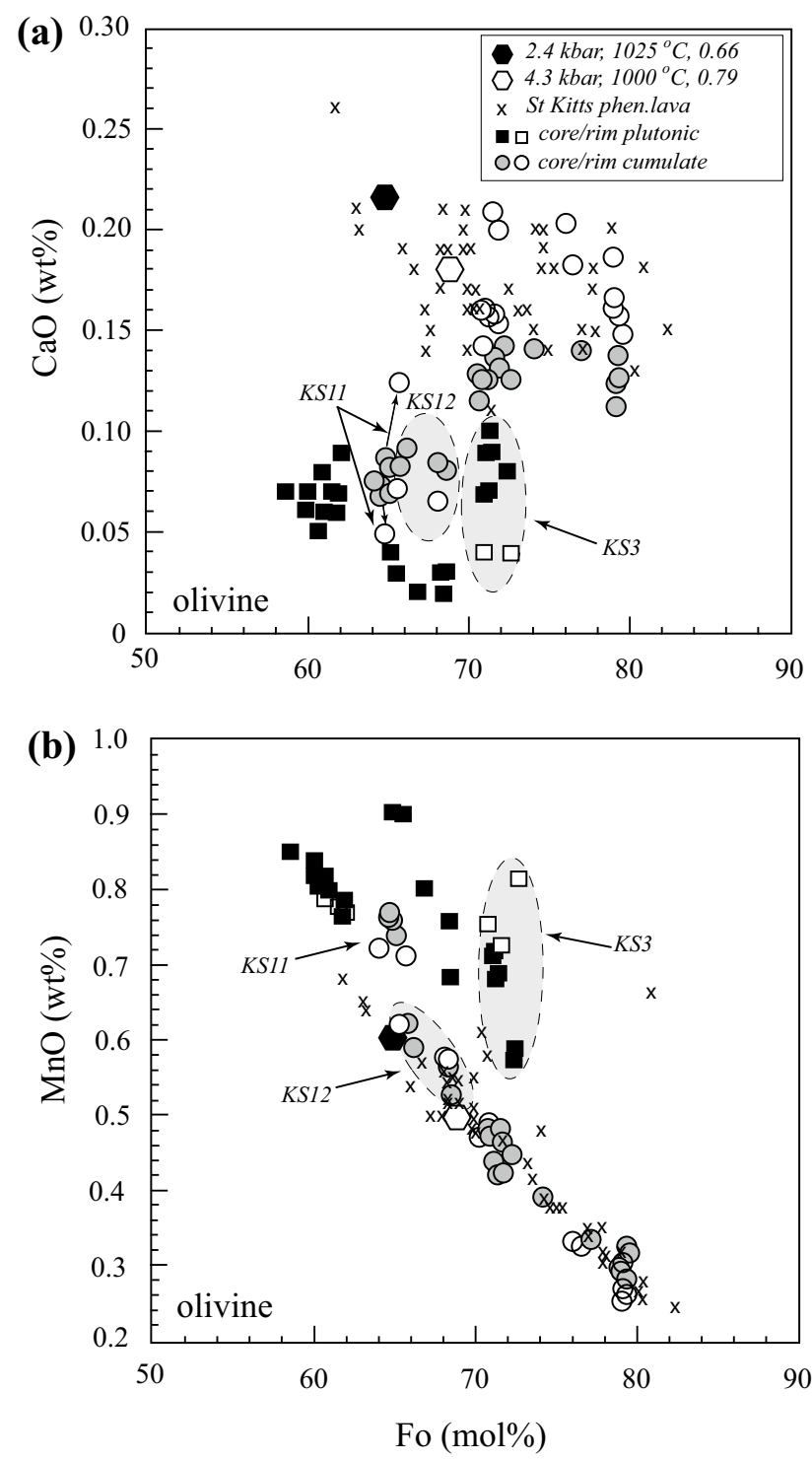

Fig. 4 Olivine compositions in terms of wt $\%$ a $\mathrm{CaO}$ and $\mathbf{b} \mathrm{MnO}$ concentration from lavas, experiments and xenoliths as a function of forsterite $(\mathrm{Fo})$ content. Olivine phenocrysts from St Kitts lavas are from Toothill et al. (2007); cumulate and plutonic xenoliths from this study (selected samples are labelled). Black and white diamonds are experimental run products from this study (Run1\#2) and HAB7 of Pichavant et al. (2002a, b) at the given $\mathrm{P}, \mathrm{T}$ and $\mathrm{XH}_{2} \mathrm{O}$

and $\mathrm{Fe}^{3+} \#\left(=\mathrm{Fe}^{3+} /\left(\mathrm{Fe}^{3+}+\mathrm{Al}\right)\right)$ versus $\mathrm{Fe}^{2+} /\left(\mathrm{Fe}^{2+}+\mathrm{Mg}\right)$ (Fig. 5). The two dominant groupings lie along the magnetite $\left(\mathrm{Fe}_{3} \mathrm{O}_{4}\right)$-spinel $\left(\mathrm{MgAl}_{2} \mathrm{O}_{4}\right)$ exchange vector: Al-rich magnetite occurs in cumulates, whereas Al-poor magnetite, coexisting with ilmenite, occurs in plutonics (Table A2 Supplementary, Fig. 5a). Phenocrysts from lavas overlap with plutonic spinel at the low-Al end of the trend. Low$\mathrm{Al}$ spinels from plutonics (notably KS-3) show a subsidiary trend to lower $\mathrm{Fe}^{2+} /\left(\mathrm{Fe}^{2+}+\mathrm{Mg}\right)$, consistent with the magnetite-magnesioferrite $\left(\mathrm{MgFe}_{2} \mathrm{O}_{4}\right)$ exchange vector. This group is found in plutonic xenoliths with olivine breakdown symplectites (Fig. 2a), although individual spinel grains within the symplectites are too small to analyse. Johnston and Stout (1984) recognized a significant magnesioferrite component in spinel associated with oxidation-related symplectites around olivine.

Clinopyroxene is present in three cumulate and four plutonic xenoliths with modal proportions from 0.8 to $18 \mathrm{wt} \%$. Texturally, clinopyroxene can be subdivided into the following groups: homogeneous crystals typical of cumulates (Fig. 2d); normally zoned clinopyroxene in plutonics with diopside cores and augite rims (KS-4); and clinopyroxene with non-systematic sectoral compositional variations. The latter are Al- and Ca-rich diopside and augite that are also high in $\mathrm{Fe}^{3+} / \Sigma \mathrm{Fe}$ (as calculated from stoichiometry), ranging from 0.1 to 0.5 .

Clinopyroxene phenocrysts from lavas and plutonic xeno-

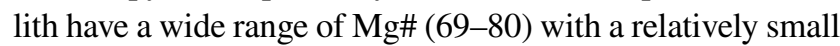
array of $\mathrm{Ca}(0.66-0.86$ apfu; Fig. 6a). The range of $\mathrm{Mg} \#$ in clinopyroxene from xenoliths is muted (70-75). Both $\mathrm{Ca}$ and tetrahedral aluminium ( $\left.\mathrm{Al}^{\mathrm{iv}}\right)$ decrease with decreasing $\mathrm{Mg \#} \mathrm{(Fig.} \mathrm{6a,} \mathrm{b),} \mathrm{although} \mathrm{the} \mathrm{Al}^{\mathrm{iv}}$ decrease is non-linear, with an abrupt drop at $\mathrm{Mg} \#$ of 75 . In contrast to olivine and spinel, there is no systematic difference between plutonic and cumulate clinopyroxenes and both varieties overlap with phenocrysts from lavas. There is a small increase of $\mathrm{TiO}_{2}(0.3-1.0)$ with increasing $\mathrm{Mg \#}$. $\mathrm{TiO}_{2}$ content in KS-7 is notably higher than all other clinopyroxenes (1.5-1.8 wt\%).

Orthopyroxene is common in St. Kitts cumulates with modal abundances $\leq 12 \%$. This is in contrast to xenoliths found on the southern islands of Grenada and St. Vincent, where orthopyroxene is common in andesite and dacite lavas, but lacking in xenoliths (Arculus and Wills 1980; Tollan et al. 2012; Stamper et al. 2014). Texturally, orthopyroxene can be divided into five groups: homogeneous phenocrysts (Fig. 2d); normally zoned chadacrysts in amphibole (KS-4, Table A2 Supplementary, Fig. 2e); phenocrysts with non-systematic sectoral zoning similar to clinopyroxene; poikilitic orthopyroxene (KS-11); and orthopyroxene-magnesioferrite symplectites (Fig. 2a). Orthopyroxene composition ranges between $\mathrm{En}_{50}$ and $\mathrm{En}_{69}$, with $\mathrm{Wo}_{\leq 3}$ (Table A2 Supplementary). Tetrahedral aluminium $\left(\mathrm{Al}^{\mathrm{IV}}\right)$ contents are low (0.005-0.12 apfu). There is a positive correlation between $\mathrm{Mg \#}$ and $\mathrm{Al}^{\mathrm{IV}}$ in xenolith orthopyroxenes (Fig. 6d), but no correlation between Ca content (0.03-0.07 pfu) and

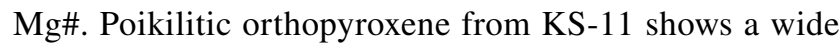
range of $\mathrm{Al}^{\mathrm{IV}}$ at similar $\mathrm{Mg \#}$. Orthopyroxene in lavas is of similar composition to xenoliths, but with a more restricted Mg\# range, 65-51.

Plagioclase is modally dominant $(\leq 80 \%)$ in all but one xenolith, KS-21 (Fig. 1a) and very calcic in composition, similar to other xenoliths from the Lesser Antilles (Baker 1968; Lewis 1973; Arculus and Wills 1980; Tollan et al. 

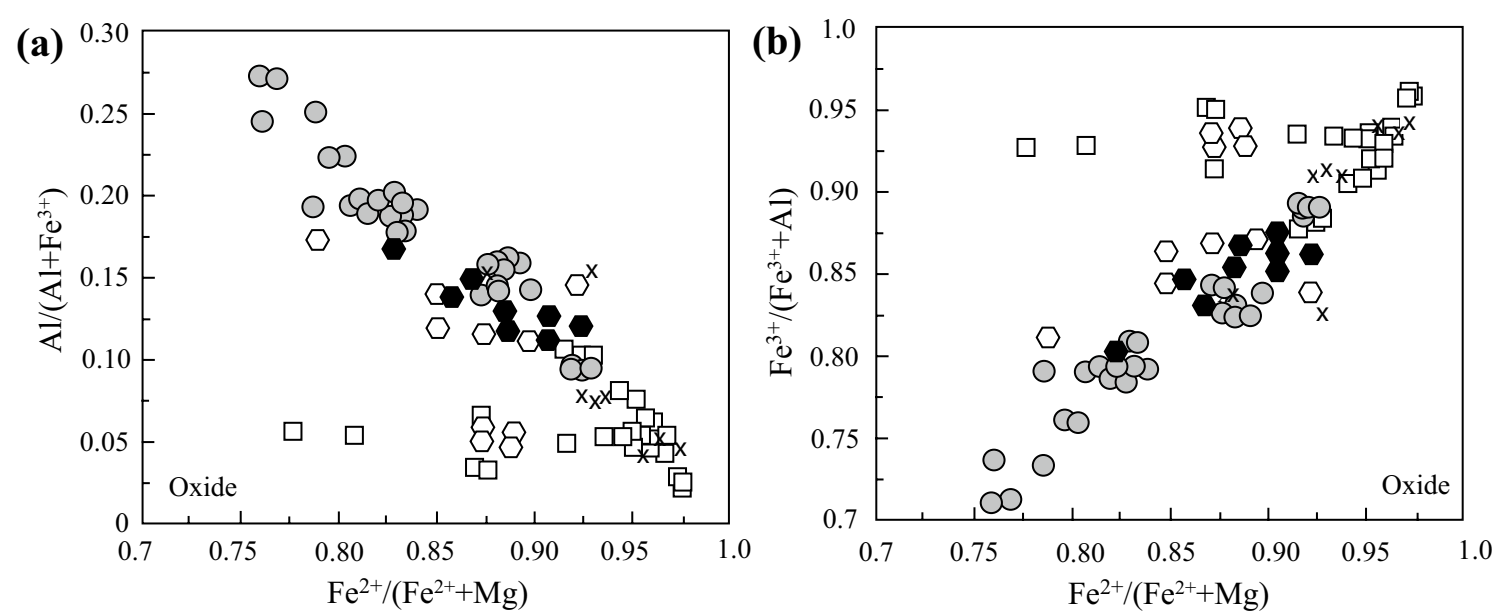

\begin{tabular}{|ll|}
\hline 2.4 kbar_this study & $\square$ plutonic \\
$\square$ 4.0 kbar_P.et al.,02 & $\bigcirc$ cumulate \\
X T. et al., 07_lava & \\
\hline
\end{tabular}

Fig. 5 Spinel compositions, expressed in terms of $\mathrm{Al} \#$ (a) and $\mathrm{Fe}^{3+} \#$ (b) versus $\mathrm{Fe}^{2+} \#$ from St. Kitts lavas (T. et al. 07-Toothill et al. 2007), cumulate and plutonic xenoliths (this study) compared with experimental spinel from Pichavant et al. 2002a, b (P.et al. 02)
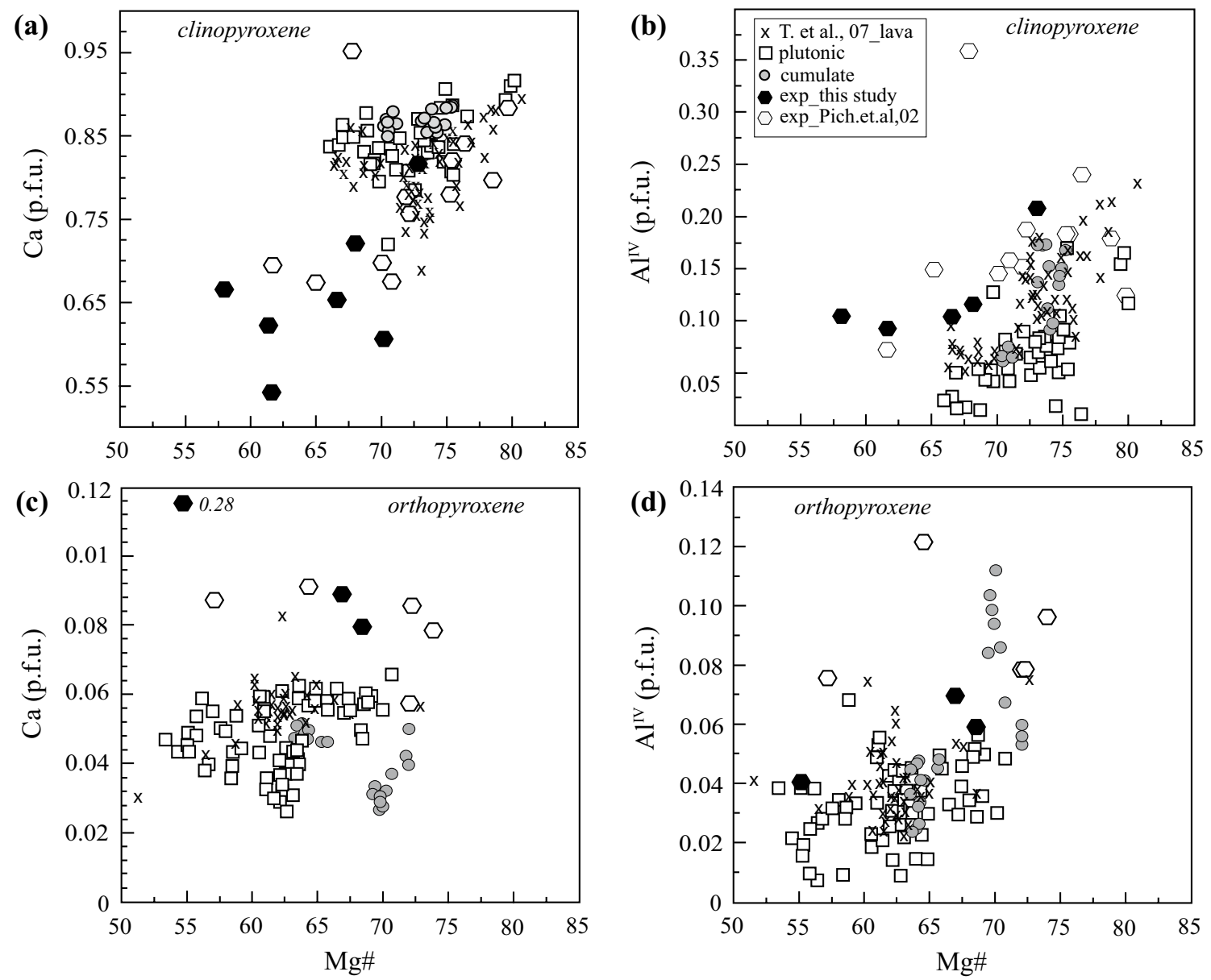

Fig. 6 Clinopyroxene (a, b) and orthopyroxene (c, d) compositions from lava phenocrysts (Toothill et al. 2007), xenoliths and experiments in terms of $\mathrm{Ca}(\mathbf{a}, \mathbf{c})$ and $\mathrm{Al}^{\mathrm{iv}}(\mathbf{b}, \mathbf{d})$, expressed as cations per

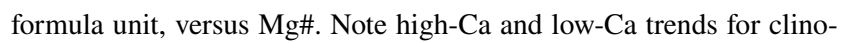
pyroxene phenocrysts from lavas (a). A single experimental pigeonite with high $\mathrm{Ca}$ is labelled 
2012; Cooper et al. 2017). However, St. Kitts plagioclase attains the most calcic compositions yet recorded, reaching almost pure anorthite $(\leq 99.9 \mathrm{~mol} \%)$ in two plutonic xenoliths (KS-16 and KS-3). There are five main textural varieties of plagioclase: (1) euhedral, high-An plagioclase without obvious zoning (e.g. KS-8, Fig. 3a and Table A2 Supplementary) or melt inclusions, confined to cumulate xenoliths; (2) plagioclase with calcic cores $\left(\mathrm{An}_{>90}\right)$ separated abruptly from less calcic $\left(\mathrm{An}_{<75}\right)$ rims with fine-scale oscillatory zoning (amplitudes of $\pm 10 \mathrm{~mol} \% \mathrm{An}$ ) and abundant glassy melt inclusions (Fig. 3c); (3) normally-zoned plagioclase with almost monotonic decline from calcic core $\left(\mathrm{An}_{>90}\right)$ to $\mathrm{An}_{50}$ rims, punctuated by occasional high amplitude ( $\leq 30 \mathrm{~mol} \% \mathrm{An}$ ) calcic spikes; (4) plagioclase lacking a high-An core, but with patchy irregular zoning and tabular textures; (5) subhedral bytownite with irregular zoning. A striking difference between plutonic and cumulate xenoliths is the range in composition. Cumulates are characterised by a limited range in An $(<15 \mathrm{~mol} \%)$, whereas plutonics may show exceptional ranges ( $\leq 50 \mathrm{~mol} \% \mathrm{An})$, even within a single crystal, consistent with protracted in situ crystallisation. $\mathrm{K}_{2} \mathrm{O}$ concentrations in plagioclase range up to $0.14 \mathrm{wt} \%$. Overall the variation in phenocryst compositions from lavas (core $\mathrm{An}_{95}$ to rim $\mathrm{An}_{60}$ ) and cumulates is less than in plutonic xenoliths (Fig. 7).

Amphibole is the second most abundant mineral in St. Kitts xenoliths, with modal proportion from 10 to $60 \%$ (Fig. 1a, Table 1), but is exceedingly rare in St. Kitts volcanics (Baker 1968; Toothill et al. 2007). Texturally, amphibole can be divided into two groups regardless of whether the xenolith is cumulate or plutonic. In the first group, amphibole forms an interlocking network of discrete,

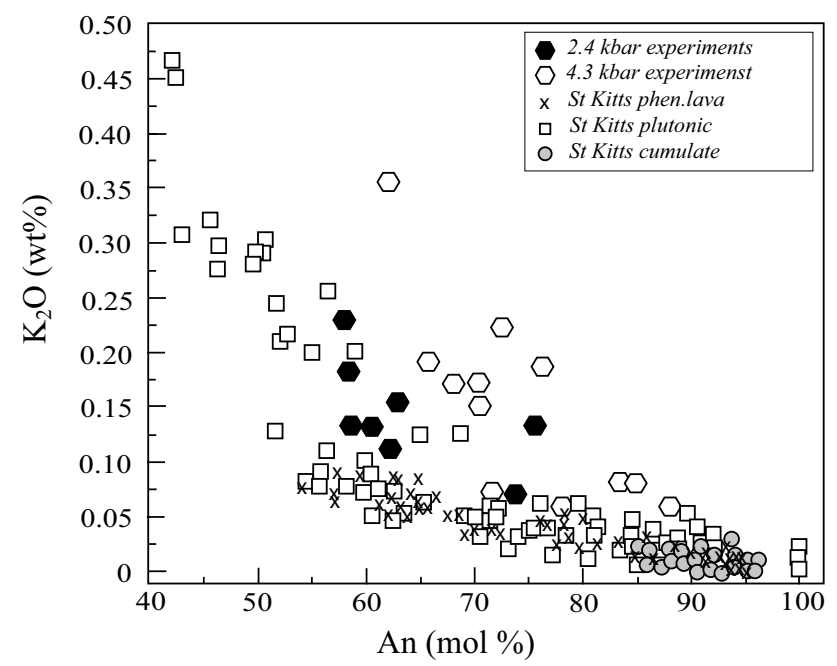

Fig. 7 Plagioclase compositions, expressed as $w t \% \mathrm{~K}_{2} \mathrm{O}$ versus An content for lava phenocrysts (Toothill et al. 2007), xenoliths and experiments at 2.4 and $4 \mathrm{kbar}$ inclusion-poor grains, appearing to crystallise as a relatively late primocryst phase (Fig. 2c, e). Rarely, amphibole has a halo of clinopyroxene, suggestive of subsequent breakdown. This is especially evident where xenoliths are in direct contact with the host lava. (e.g. KS-24, Fig. 3f). In the second group, amphibole is an interstitial phase. In many samples, the interstitial amphiboles form large, optically continuous poikilocrysts, up to several $\mathrm{mm}$ across. Inclusions of olivine, oxides, clinopyroxene and plagioclase are common, and evidence of amphibole-clinopyroxene reaction is widespread around grain margins, along cleavage planes, or within poikilocryst interiors (Fig. 3d). This texture, which is widespread in cumulate xenoliths, is reminiscent of the distribution of residual melt, and suggestive of percolation of reactive hydrous melt or fluids through an anhydrous crystal mush, as documented in xenoliths from Martinique (Cooper et al. 2017), Grenada (Stamper et al. 2014) and the Solomon Islands (Smith 2014).

According to the classification scheme of Leake et al. (1997, 2004), most St. Kitts amphibole is magnesiohastingsite with lesser tschermakite (KS-16, KS-31 and KS-4). $\mathrm{Mg} \#$, calculated with Fe total, is between 52 and 76. Subhedral and euhedral amphibole is normally zoned with $<5 \%$ variation in $\mathrm{Mg \#}$. There is no difference in amphibole composition between clinopyroxene-bearing and clinopyroxenefree xenoliths, although plutonic and cumulate amphibole differs markedly (Fig. 8a). Plutonic amphibole has lower $\mathrm{Mg} \#\left(64-54\right.$, Fig. 8a) and $\mathrm{Al}^{\mathrm{IV}}$ ( $\left.\leq 1.8 \mathrm{apfu}\right)$, whereas cumulate amphibole has higher $\mathrm{Mg \#}(76-60)$ and higher $\mathrm{Al}^{\mathrm{IV}}$ (1.6-2.2 apfu). Titanium contents are in the range 0.15 and 0.40 a.p.f.u. with trends of increasing or decreasing $\mathrm{Ti}$ with Mg\# (Fig. 8b) according to the nature of the coexisting oxide mineralogy. Amphiboles on the increasing Ti trend come from xenolith that contain only magnetite (shown by arrows on Fig. 8b), whereas those on the decreasing trend come from samples with ilmenite. Viewed as a suite, amphibole trends resemble a fractionation sequence with Ti increasing to the point of ilmenite saturation and then decreasing.

Glass occurs as melt inclusions in crystals and as interstitial pockets, often vesiculated, in both xenolith varieties. Inclusions, ranging in size from $\leq 10$ to $200 \mu \mathrm{m}$ and from clear to brown in colour, are common in plagioclase and amphibole, and less so in olivine, pyroxenes and oxides. Inclusions often contain gas bubbles with typical volume fractions from 0 to $10 \%$, and rarely $20-50 \%$ (Fig. 2f). Inclusions in olivine are usually devitrified or too small to analyse.

Eleven melt inclusions and 13 interstitial glasses were selected for analysis (Table A2 and Table A4 Supplementary). Selected inclusions show no signs of post-entrapment leakage or devitrification. They range in composition from dacite to rhyolite $\left(63.1-74.8 \mathrm{wt} \% \mathrm{SiO}_{2}\right.$ on an anhydrous basis) with no systematic correlation with the nature of the 


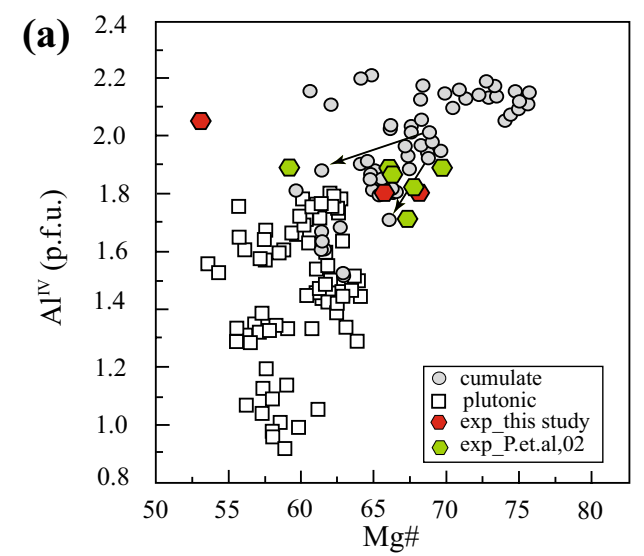

Fig. 8 Amphibole compositions from St Kitts xenoliths and experiments expressed in terms of $\mathrm{Al}^{\mathrm{iv}}$ and $\mathrm{Ti}$, expressed as cations per formula unit, versus $\mathrm{Mg \#}$. Arrows on panel a show decrease in $\mathrm{Al}^{\mathrm{iv}}$ from core to rim in KS-15. Ti content of amphibole $\mathbf{b}$ strongly depends on

host crystal (Table A3 Supplementary and Fig. 9). Interstitial melt and melt inclusions are compositionally similar, although the former have lower $\mathrm{H}_{2} \mathrm{O}$ and, unusually, higher $\mathrm{CO}_{2}$ contents (Table A4 Supplementary). Melt inclusions from plutonic xenoliths are systematically more evolved (66.0-74.8 $\mathrm{wt} \% \mathrm{SiO}_{2}$ ) than those from cumulates, which are consistently andesitic $\left(63.1-66.0 \mathrm{wt} \% \mathrm{SiO}_{2}\right)$. The occurrence of andesitic melt inclusions is surprisingly rare in global compilations of melt inclusions in volcanic rocks (Reubi and Blundy 2009). In fact, three melt inclusions with $>6 \mathrm{wt} \%$ $\mathrm{H}_{2} \mathrm{O}$ and $65-67 \mathrm{wt} \% \mathrm{SiO}_{2}$ lie in the compositional gap shown by Reubi and Blundy (2009).

Overall, melt inclusions describe a fractionation trend from andesite to dacite (Fig. 9). Melt compositions overlap the silica-rich end of the whole-rock compositions of erupted lavas of St. Kitts and so provide information on the more evolved end of the liquid line of descent (Fig. 9). A striking feature of melt inclusions with $<3 \mathrm{wt} \% \mathrm{MgO}$ is the trend to lower $\mathrm{Na}_{2} \mathrm{O}$. All melt inclusions were analysed using a defocussed electron beam and, as there is no correlation between $\mathrm{Na}_{2} \mathrm{O}$ and $\mathrm{H}_{2} \mathrm{O}$ contents, we do not consider this to be an analytical artefact. Instead, in the absence of any Na-rich crystallising phase, this behaviour is suggestive of sequestration of $\mathrm{Na}_{2} \mathrm{O}$ into an exsolving volatile phase. In that case the $\mathrm{Na}_{2} \mathrm{O}$ maximum $(\sim 4.5 \mathrm{wt} \%)$ in whole-rocks and melt inclusions at around $3 \mathrm{wt} \% \mathrm{MgO}$ would correspond to the onset of significant volatile exsolution.

Water content in melt inclusions, as measured by SIMS, ranges from $8.5 \mathrm{wt} \%$ to below detection. Melt inclusions in plagioclase $\left(\mathrm{An}_{86-79}\right.$ and $\left.\mathrm{An}_{59}\right)$ show a broad range from 8.2 to $2.5 \mathrm{wt} \%$, with the lower $\mathrm{H}_{2} \mathrm{O}$ associated with the less calcic hosts (Table A2 Supplementary, Fig. 10). $\mathrm{CO}_{2}$ contents range from below detection to over $1000 \mathrm{ppm}$, but do not correlate with $\mathrm{H}_{2} \mathrm{O}$ (Fig. 10). Notably, two interstitial

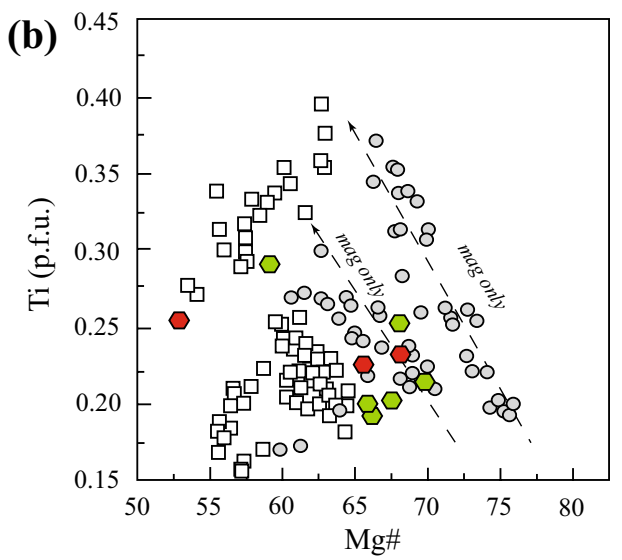

composition of co-crystallising oxides. Magnetite only (mag only) arrows show negative correlation of $\mathrm{Ti}$ and $\mathrm{Mg} \#$ in cumulate xenoliths. Ilmenite is present only in plutonic xenoliths, giving rise to lowTi amphiboles

glasses (not plotted on Fig. 10) from KS-15 have high $\mathrm{CO}_{2}$ ( $>1000 \mathrm{ppm})$ but low $\mathrm{H}_{2} \mathrm{O}(<1.6 \mathrm{wt} \%)$. Inclusions with lower $\mathrm{H}_{2} \mathrm{O}$ or $\mathrm{CO}_{2}$ are not associated with the bigger vapour bubbles. The high $\mathrm{H}_{2} \mathrm{O}$ content of many inclusions argues against significant $\mathrm{H}_{2} \mathrm{O}$ loss by diffusion through the host mineral, consistent with rapid pre-eruptive entrainment of the xenoliths in their host magma.

Chlorine contents are consistently high, reaching $3000 \mathrm{ppm}$ in some melt inclusions (Table A3 Supplementary). Sulphur contents are low ( $<350 \mathrm{ppm})$ consistent with the presence of sulphide minerals in many samples. There is no clear correlation between $\mathrm{H}_{2} \mathrm{O}$ and any other volatiles species. However, there is a positive correlation between sulphur and chlorine and $\mathrm{CO}_{2}$ indicative of degassing. Chlorine increases with decreasing $\mathrm{MgO}$, consistent with the incompatible behaviour of $\mathrm{Cl}$ and limited partitioning of $\mathrm{Cl}$ into exsolving fluids (cf. Blundy et al. 2008).

\section{Intensive parameters of xenolith formation}

\section{Thermometry and oxybarometry}

Studies of xenoliths from other Lesser Antilles islands (Cooper et al. 2017; Melekhova et al. 2015; Stamper et al. 2014; Tollan et al. 2012) show that $\mathrm{T}-\mathrm{P}-a \mathrm{H}_{2} \mathrm{O}-f \mathrm{O}_{2}$ conditions under which xenoliths formed can vary widely, even for a single island. Nonetheless, the majority of xenoliths formed at pressures $\leq 4 \mathrm{kbar}$ from magmas with initial $\mathrm{H}_{2} \mathrm{O}$ content between 2.5 and $4.5 \mathrm{wt} \%$, and $f \mathrm{O}_{2}$ ranging from 0.5 to $4.5 \log$ units above NNO. Here we use mineral and melt chemistry of St. Kitts xenoliths to constrain intensive parameters with the following oxythermobarometers (Table 4): amphibole-plagioclase thermometer of Holland and Blundy (1994), hornblende-liquid thermobarometer of 
Fig. 9 Chemical composition of experimental melts (exp. melt) and solid residues (exp. solid) from this study compared with bulk-rock major element variations in St Kitts lavas (Toothill et al. 2007; Turner et al. 1996; Baker 1984), melt inclusions in phenocrysts from cumulates (this study) and lavas (Toothill et al. 2007), and cumulate xenoliths (calculated from mineral modes and EMPA data). Experimental melts from Pichavant et al. 2002a, b (Pich. et al. 2002) also shown for comparison. St.mat. starting material, cumul/plut cumulate xenolith/plutonic xenolith, MI\&inter.m melt inclusions and interstitial melt. Continuous and dashed lines illustrate melt evolution in experiments with $X \mathrm{H}_{2} \mathrm{O}=1$ and $X \mathrm{H}_{2} \mathrm{O}=0.66$, respectively. The trend to low $\mathrm{Na}_{2} \mathrm{O}$ in the latter experiments reflects, in part, Na loss during EMP analysis (Table 3)
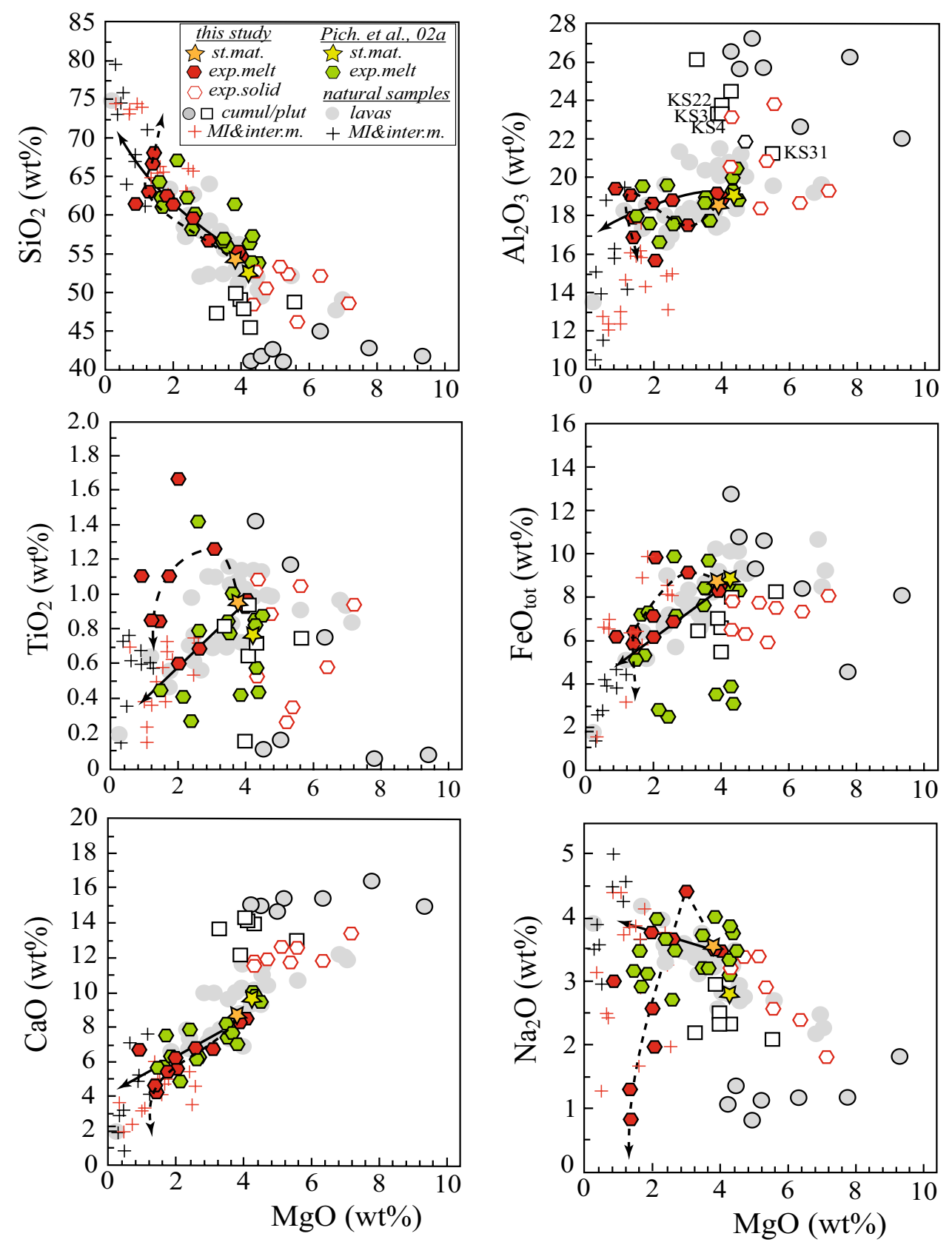

Putirka (2016), and magnetite-ilmenite oxythermometers of Ghiorso and Evans (2008) and Andersen and Lindsley (1985). Note that amphibole-plagioclase thermometry is limited to plagioclase less calcic than $\mathrm{An}_{90}$ (Holland and Blundy 1994), a requirement met by only three xenoliths.

With a few exceptions, we find good agreement between different thermometers $\left( \pm 40{ }^{\circ} \mathrm{C}\right)$ applied to the same sample. Plutonic xenoliths generally record lower temperatures (890-770 ${ }^{\circ} \mathrm{C}$ ) than cumulate xenoliths, consistent with their more complex textures and mineralogy and more evolved melt inclusions. The presence of exsolved $\mathrm{Fe}-\mathrm{Ti}$ oxides in KS-3 (Fig. 2b) yields subsolidus temperatures suggestive of protracted cooling. Cumulate xenolith temperatures are in the range $1020-890^{\circ} \mathrm{C}$.

Oxygen fugacity $\left(f \mathrm{O}_{2}\right)$ for plutonic xenoliths, calculated from coexisting $\mathrm{Fe}-\mathrm{Ti}$ oxides, lies between NNO and $\mathrm{NNO}+1$ for all but KS3, which records a significantly higher $\mathrm{fO}_{2}(\mathrm{NNO}+2)$, consistent with the interpretation of symplectites around olivine (Fig. 2a) as products of oxidation, possibly associated with cooling. The calculated $f \mathrm{O}_{2}$ values for St. Kitts lavas estimated by Toothill et al. (2007) have a similar range, $\Delta \mathrm{NNO} \pm 1$, to the un-oxidised plutonic xenoliths. It was not possible to calculate $f_{2}$ for the cumulate xenoliths due to lack of an appropriate assemblage. 


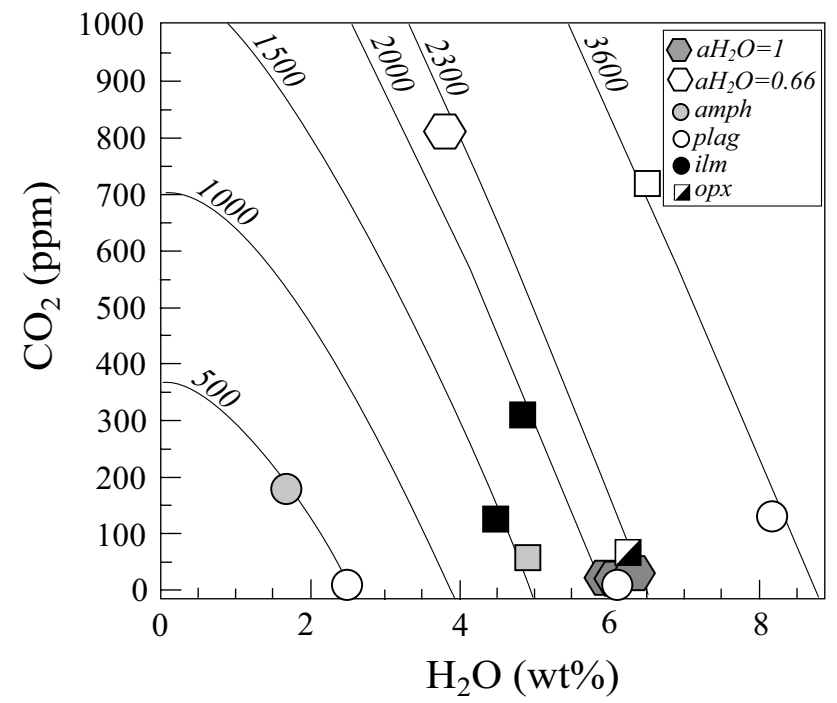

Fig. 10 Volatile contents of melt inclusions and experimental glasses. Solid lines are illustrative isobars for generic basalt at $1000{ }^{\circ} \mathrm{C}$ after Newman and Lowenstern (2002)

\section{Apatite saturation temperatures}

The melt inclusions show a trend of decreasing $\mathrm{P}_{2} \mathrm{O}_{5}$ with increasing $\mathrm{SiO}_{2}$, consistent with apatite saturation. We have used the algorithm of Harrison and Watson (1983) to calculate apatite saturation temperatures for each melt inclusion. Values range from 870 to $994{ }^{\circ} \mathrm{C}$ (Table A3 Supplementary), and are generally in good agreement with mineral thermometry. For the four plagioclase-hosted melt inclusions that have retained their volatile contents, we have also calculated plagioclase-melt temperatures using the algorithm of Putirka (2005). These range from 839 to $972{ }^{\circ} \mathrm{C}$, within $40{ }^{\circ} \mathrm{C}$ of the apatite saturation temperatures.

\section{Volatile saturation pressures}

We calculated $\mathrm{H}_{2} \mathrm{O}$ and $\mathrm{CO}_{2}$ saturation pressures for melt inclusions and interstitial glasses at the calculated apatite saturation temperatures (Table A3 Supplementary) and $f \mathrm{O}_{2}=\mathrm{NNO}+1$ using the MagmaSat algorithm of Ghiorso and Gualda (2015). Values range from 0.5 to $3.8 \mathrm{kbar}$, with fluid compositions ranging from $\mathrm{XH}_{2} \mathrm{O}$ of $0-1$. There is no correlation between calculated pressures and host mineral or xenolith textural type. However, it is striking that the interstitial glasses from KS-15 with high $\mathrm{CO}_{2}$ and low $\mathrm{H}_{2} \mathrm{O}$ record similar pressures $(2.6$ and $2.8 \mathrm{kbar})$ to the melt inclusions. This behaviour is suggestive of flushing of the magma with $\mathrm{CO}_{2}$-rich fluids prior to eruption (e.g. Blundy et al. 2010), displacing the interstitial melts along isobars, but without affecting the melt inclusions due to very slow intracrystalline diffusion of $\mathrm{CO}_{2}$.
Multiple reaction barometry

Two of the St. Kitts cumulate xenoliths (KS17, KS7) have the assemblage spinel-clinopyroxene-olivine-plagioclase, which has been developed as a geobarometer for mafic rocks using a multiple reaction method (Ziberna et al. 2017). We calculated pressures using mineral analyses from immediately adjacent, texturally equilibrated grains. The values are $6.4 \pm 1.8 \mathrm{kbar}$ for KS-7 and $6.0 \pm 1.2 \mathrm{kbar}$ for $\mathrm{KS}-17$, lying at the upper limit of volatile saturation pressures from other xenoliths. Unfortunately, there are no melt inclusions in KS17, KS7 with which to make direct comparisons of these two methods.

\section{Experimental petrology}

Experimental run conditions and phase proportions are given in Table 3, along with relative $\mathrm{Na}$ loss, and $\mathrm{H}_{2} \mathrm{O}$ and $\mathrm{CO}_{2}$ content of quenched glasses analysed by SIMS. For runs in which volatile contents of quenched glass could not be analysed because of an abundance of crystals and very small pool sizes, $\mathrm{H}_{2} \mathrm{O}$ and $\mathrm{CO}_{2}$ concentrations were estimated using MagmaSat (Ghiorso and Gualda 2015). In the four experiments where SIMS analyses were possible, the measured values and those calculated using MagmaSat are in good agreement (Table 3). All experiments are vapour-saturated as evidenced by presence of vapour bubbles in quenched run products. In three water-saturated runs $\left(a \mathrm{H}_{2} \mathrm{O}=1.0\right), \mathrm{H}_{2} \mathrm{O}$ concentration in the melt is around $6 \mathrm{wt} \%$ with 16-30 ppm $\mathrm{CO}_{2}$, likely introduced as a trace contaminant in the starting materials. The obtained data are in very good agreement with water solubility data of Botcharnikov et al. (2006) for andesitic melts at $200 \mathrm{MPa}$ and 1100-1300 ${ }^{\circ} \mathrm{C}$. The composition of the coexisting fluid was determined from the composition of the fluid added to the starting material, the measured glass volatile contents and the glass fraction determined by mass balance. As expected, the equilibrium fluid composition is $\mathrm{H}_{2} \mathrm{O}$-poor compared to the starting material because of the greater solubility of $\mathrm{H}_{2} \mathrm{O}$ compared to $\mathrm{CO}_{2}$.

All experiments are crystallisation experiments where crystals nucleate and grow from the melt. No reversals were performed. Consequently, equilibrium in each individual experiment cannot be proven unequivocally. However, systematic variations in melt chemistry, melt fraction and mineral assemblages with changing temperature, together with homogeneous phase compositions, suggest close approach to equilibrium. Likewise, observed crystal textures and morphologies argue against significant problems with nucleation. Phases are homogeneously distributed throughout the capsule and crystals have euhedral shapes, although in two experiments (Run1\#2 and Run2\#2), skeletal orthopyroxene is suggestive of rapid growth. Residuals from mass 


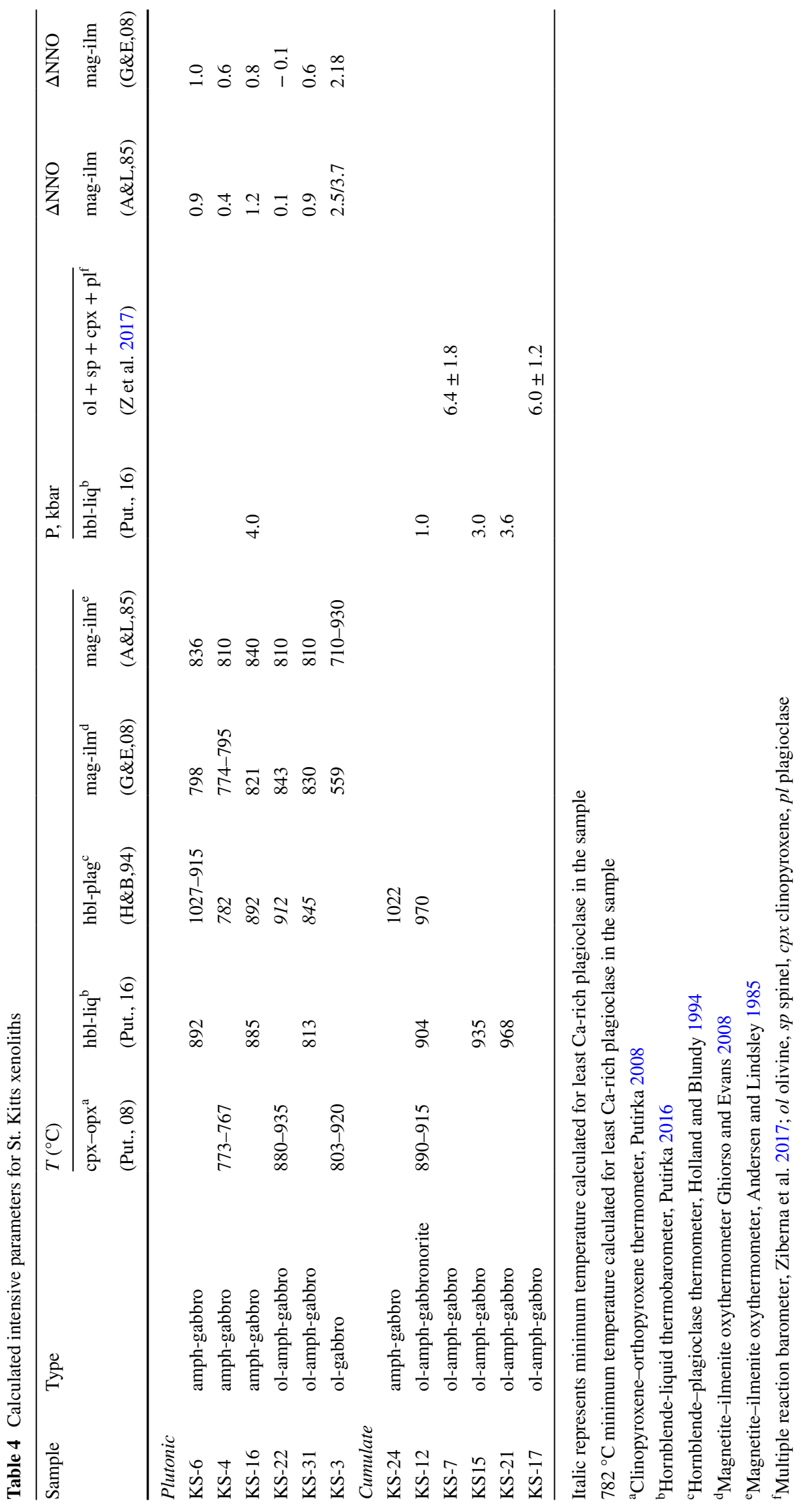


balance calculations show that bulk silicate composition was maintained successfully with apparent Fe loss or gain less than $1 \%$. Sodium loss is apparent in some crystal-rich runs with reduced $a \mathrm{H}_{2} \mathrm{O}$. This is likely a result of focused-beam EPMA, although we cannot rule out some $\mathrm{Na}$ loss to the fluid, as inferred from $\mathrm{Na}$ systematics in natural St. Kitts glasses. No quench crystals occur in any of the run product glasses. Crystalline phases and glass were analysed by microprobe (Table 5) in all but two experiments Run3\#3 and Run4\#3 where the crystals and glass pools were $\sim 1$ micron. Amphibole in Run3\#2 was too small to gain reliable analyses.

\section{Phase relations}

A phase diagram for experimental series with different $a \mathrm{H}_{2} \mathrm{O}$ is shown in Fig. 11a in terms of $\mathrm{H}_{2} \mathrm{O}$ in melt $\left(\mathrm{H}_{2} \mathrm{O}^{\text {melt }}\right)$. Pichavant et al. (2002a, b) carried out experiments at 4 kbar on a basaltic andesite from Martinique (Table 2) that is very similar to the starting composition used in this study. Their experiments used a similar approach and can be usefully combined with ours (Fig. 11b).

The $\mathrm{H}_{2} \mathrm{O}$-saturated liquidus for basaltic andesite is $1025^{\circ} \mathrm{C}$ and $2.4 \mathrm{kbar}\left(6 \mathrm{wt} \% \mathrm{H}_{2} \mathrm{O}^{\text {melt }}\right.$; Fig. 11a) and $1015^{\circ} \mathrm{C}$

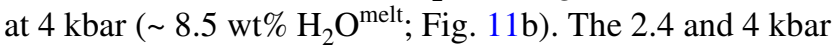
phase diagrams have very similar topology. Their watersaturated crystallisation sequences are alike (olivine-clinopyroxene-plagioclase-amphibole), although the $4 \mathrm{kbar}$ experiments lie closer to multiple saturation, with the latter three phases appearing within $\sim 10^{\circ} \mathrm{C}$ of the liquidus. Magnetite is present in all experiments and is a near-liquidus or liquidus phase. Clinopyroxene reacts out between 975 and $950{ }^{\circ} \mathrm{C}$ at both 2.4 and $4 \mathrm{kbar}$. In this region, amphibole is the only ferromagnesian mineral at elevated $\mathrm{H}_{2} \mathrm{O}^{\text {melt }}$.

The $\mathrm{H}_{2} \mathrm{O}$-undersaturated liquidus is displaced to higher temperatures, but was not determined at either 2.4 or 4 kbar. With decreasing $a \mathrm{H}_{2} \mathrm{O}$, plagioclase saturation is displaced to higher temperatures and amphibole to lower temperature. The limiting $\mathrm{H}_{2} \mathrm{O}^{\text {melt }}$ content for amphibole stability is $6 \mathrm{wt} \%$ at 4 kbar. At $2.4 \mathrm{kbar}$, the lower $\mathrm{H}_{2} \mathrm{O}^{\text {melt }}$ content for amphibole stability is less well defined, but likely lies just below $4 \mathrm{wt} \%$. The field of clinopyroxene stability expands with decreasing $\mathrm{H}_{2} \mathrm{O}^{\text {melt }}$. A striking effect of reduced $a \mathrm{H}_{2} \mathrm{O}$ is the appearance of orthopyroxene for $\mathrm{H}_{2} \mathrm{O}^{\text {melt }}$ contents below $5 \mathrm{wt} \%$ at $2.4 \mathrm{kbar}$ and $6.5 \mathrm{wt} \%$ at $4 \mathrm{kbar}$. The olivine stability field is very restricted, reflecting the relatively low $\mathrm{MgO}$ content of the starting composition. Olivine is present only at $1025^{\circ} \mathrm{C}, 2.4 \mathrm{kbar}$ and at $1000{ }^{\circ} \mathrm{C}, 4 \mathrm{kbar}$ with $\mathrm{H}_{2} \mathrm{O}^{\text {melt }}$ of 3.8 and $6.8 \mathrm{wt} \%$, respectively. Ilmenite is a low temperature phase, appearing below $960{ }^{\circ} \mathrm{C}$ at both pressures, but stable to higher $\mathrm{H}_{2} \mathrm{O}^{\text {melt }}$ at $4 \mathrm{kbar}$. The compositions of experimental run products show strong variation with intensive parameters (Table 5). The degree of crystallisation increases non-linearly with decreasing $a \mathrm{H}_{2} \mathrm{O}$ (Table 3).

\section{Oxides}

Titaniferous magnetite $\left(\mathrm{TiO}_{2} \sim 7-18 \%\right)$ is the dominant oxide phase forming euhedral crystals $1-10 \mu \mathrm{m}$ in size in all experiments. In Run4\#3, magnetite coexists with ilmenite. The $\mathrm{TiO}_{2}$ content of magnetite increases with decreasing $\mathrm{H}_{2} \mathrm{O}^{\text {melt }}$ (Table 5) and there is a slight negative correlation of $\mathrm{TiO}_{2}$ with temperature. $\mathrm{Al} \#$ in magnetite increases and $\mathrm{Fe}^{3+} \#$ decreases with increasing temperature and $\mathrm{H}_{2} \mathrm{O}^{\text {melt }}$. Al\# and $\mathrm{Fe}^{3+} \#$ concur with the data of Pichavant et al. $(2002 \mathrm{a}, \mathrm{b})$ at comparable $\mathrm{fO}_{2}$ (Fig. 5). However, magnetite from this study is higher in $\mathrm{TiO}_{2}$ compared to magnetite from Pichavant et al. (2002a, b), probably because of slight differences in $\mathrm{TiO}_{2}$ content of starting compositions (Table 2). Magnetite in experiments HAB21, HAB20 and HAB23, HAB24 of Pichavant et al. (2002a, b) has a low-Al composition similar to that from KS-3 (Fig. 5) and distinct from the rest of the experimental magnetites. These four experiments were run under relatively oxidised conditions $(\Delta \mathrm{NNO}+3.1$ to +3.8$)$ consistent with the textural inference that KS-3 experienced oxidation during differentiation, driving spinel towards magnesioferrite composition. Experimental magnetite compositions match natural phenocrysts.

Olivine $\left(\mathrm{Fo}_{65}\right)$ is present in one experiment at $2.4 \mathrm{kbar}$. It is high in $\mathrm{CaO}$ and relatively high in $\mathrm{MnO}$ (Fig. 4). The 4 kbar olivine (run HAB7) of Pichavant et al. (2002a, b) is slightly more magnesian $\left(\mathrm{Fo}_{69}\right)$ but a little lower in $\mathrm{CaO}$ and $\mathrm{MnO}$. Experimental olivines match phenocrysts from St. Kitts lavas and cumulate xenoliths, but differ from plutonic xenoliths in terms of $\mathrm{CaO}$ and $\mathrm{MnO}$ contents (Fig. 4).

\section{Pyroxenes}

Clinopyroxene compositions range from diopside to augite. In Run2\#3, diopside coexists with pigeonite. Clinopyroxene is high in $\mathrm{Al}_{2} \mathrm{O}_{3}\left(\mathrm{Al}^{\mathrm{IV}}\right.$ from 0.08 to $\left.0.21 \mathrm{apfu}\right)$ and correlates positively with $\mathrm{Mg \#} \mathrm{(Fig.} \mathrm{6b)} \mathrm{and} \mathrm{H}_{2} \mathrm{O}^{\text {melt }}$, which probably reflects the delay in the onset of plagioclase crystallisation. Ca contents are strongly correlated with Mg\# (Fig. 6a). Clinopyroxene in the 4 kbar experiments of Pichavant et al. (2002a, b) has higher Ca and Mg\# than at 2.4 kbar (Fig. 6a). Orthopyroxene is enstatite with low $\mathrm{Al}_{2} \mathrm{O}_{3}$ (1.8-2.7 wt\%). There is a decrease of $\mathrm{Al}^{\mathrm{IV}}$ and $\mathrm{Mg \#}$ and an increase of $\mathrm{TiO}_{2}$ with deceasing $a \mathrm{H}_{2} \mathrm{O}$ (Table 5, Fig. 6c). Ca increases with decreasing Mg\# (Fig. 6d). In general, clinopyroxene that coexists with orthopyroxene has lower Ca contents, due to buffering along the pyroxene solvus. Coexisting pyroxenes from Runs \#1-2 and 2-2 yield two-pyroxene temperatures, using Eq. (37) of Putirka (2008), of 1056 and $1028{ }^{\circ} \mathrm{C}$, respectively. The $\mathrm{Mg \#}$ range of experimental and 


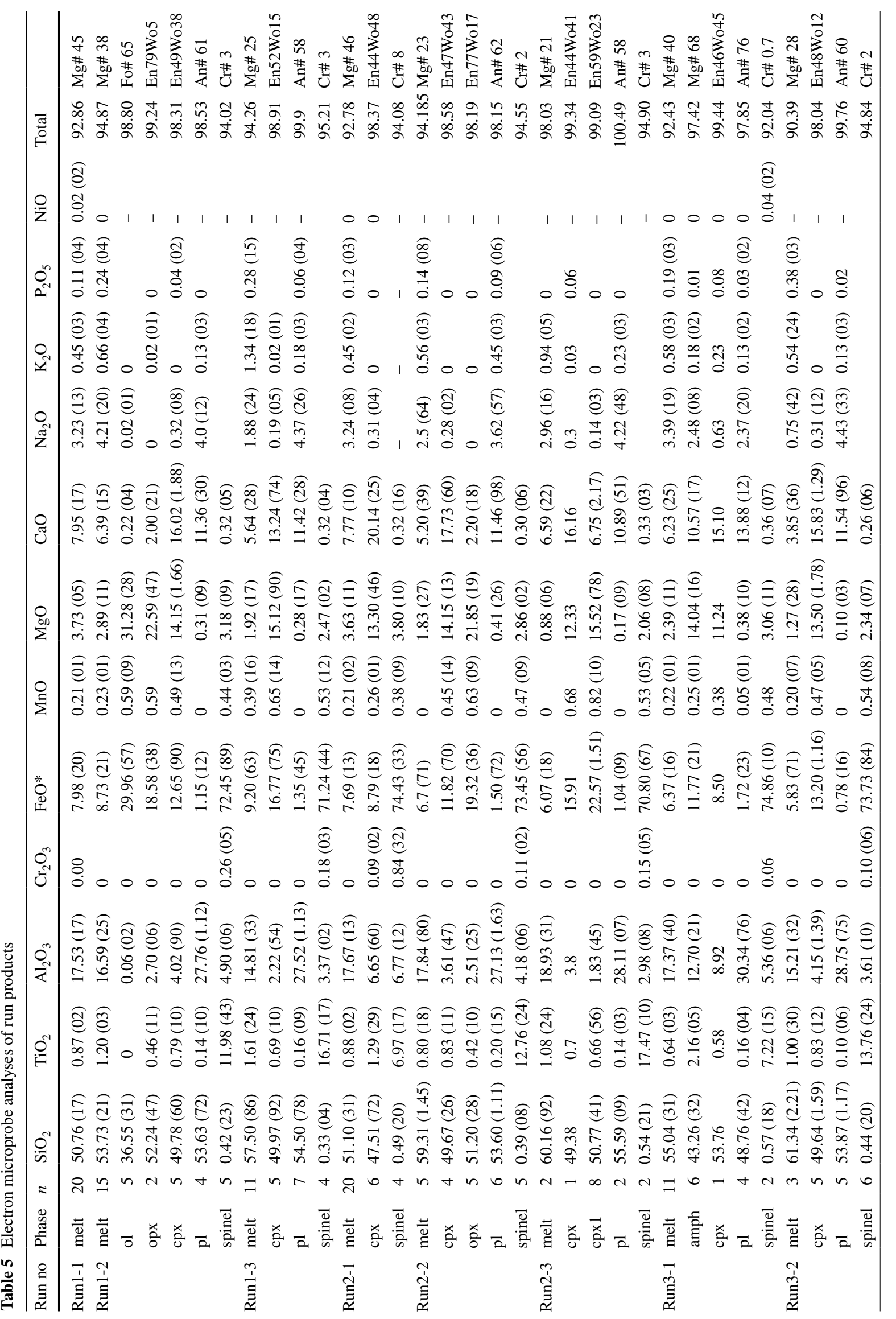




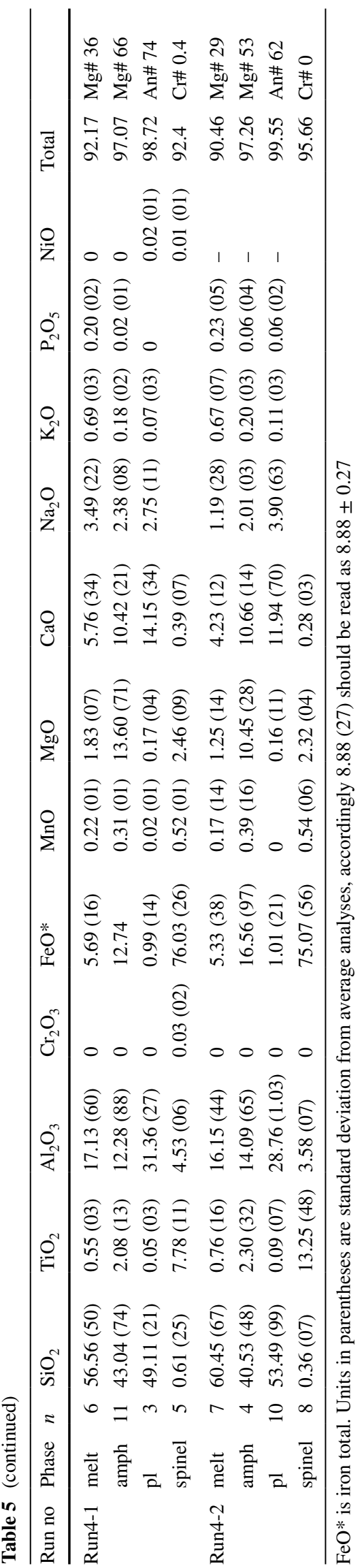

natural pyroxenes is similar. Experimental clinopyroxene is displaced to lower $\mathrm{Ca}$ and higher $\mathrm{Al}^{\mathrm{IV}}$ than its natural counterpart, whereas orthopyroxene is higher in $\mathrm{Al}^{\mathrm{IV}}$ and $\mathrm{Ca}$. The closest match to natural lava pyroxenes is found in $\mathrm{H}_{2} \mathrm{O}$-saturated experiments at $4 \mathrm{kbar}, 1000$ and $1016{ }^{\circ} \mathrm{C}$ (HAB24 and HAB18, Pichavant et al. 2002a, b) and at 2.4 kbar, $1000{ }^{\circ} \mathrm{C}$ (Run2\#1).

Plagioclase compositions range from $\mathrm{An}_{58}$ to $\mathrm{An}_{74}$ at 2.4 kbar (Fig. 1b) and from $\mathrm{An}_{62}$ to $\mathrm{An}_{89}$ at $4 \mathrm{kbar}$ (Pichavant et al. 2002a, b). Plagioclase shows a negative correlation between $\mathrm{K}_{2} \mathrm{O}$ wt\% and An (Fig. 7). Pichavant et al. (2002a, b) used a starting composition that had about $50 \%$ more $\mathrm{K}_{2} \mathrm{O}$ than KS_BR1 (Table 2), resulting in elevated plagioclase $\mathrm{K}_{2} \mathrm{O}$ content. Anorthite content increases with increasing $\mathrm{H}_{2} \mathrm{O}^{\text {melt }}$ at a given temperature, but does not change significantly with temperature at fixed $\mathrm{H}_{2} \mathrm{O}^{\text {melt }}$ (Fig. 11). For example, at $950{ }^{\circ} \mathrm{C}$ and $4 \mathrm{~kb}$, An falls from $89 \mathrm{~mol} \%$ at $8 \mathrm{wt} \% \mathrm{H}_{2} \mathrm{O}^{\text {melt }}$ to $62 \mathrm{~mol} \%$ at $6 \mathrm{wt} \% \mathrm{H}_{2} \mathrm{O}^{\text {melt }}$; at $2.4 \mathrm{kbar}$ the difference between runs with $\mathrm{H}_{2} \mathrm{O}^{\text {melt }}$ of 6.4 and $3.8 \mathrm{wt} \%$ is $\mathrm{An}_{74}$ and $\mathrm{An}_{62}$, respectively. Conversely, the difference between An content of plagioclase at 1025 and $950{ }^{\circ} \mathrm{C}$ in 2.4 kbar experiments with $3.8 \mathrm{wt} \% \mathrm{H}_{2} \mathrm{O}$ is within analytical error. Experiments at $2.4 \mathrm{kbar}$ failed to replicate the very high An content of natural plagioclases. The most calcic experimental plagioclase is $\mathrm{An}_{89}$ in an experiment at $4 \mathrm{kbar}$, $950{ }^{\circ} \mathrm{C}$. According to the phase diagram in Fig. $11 \mathrm{~b}$ plagioclase is stable to higher temperatures than $950{ }^{\circ} \mathrm{C}$ at $8.5 \mathrm{wt} \% \mathrm{H}_{2} \mathrm{O}^{\text {melt }}$, so plausibly even more calcic plagioclase could form under these conditions. However, we consider it unlikely that plagioclase with more than $99 \mathrm{~mol} \%$ An could ever crystallise from Na-bearing silicate melts, unless the topology of the plagioclase binary changes dramatically at An-rich compositions, as proposed by Nekvasil et al. (2015).

Amphibole, analysed in three run products, has 12.3-14.1 wt $\% \mathrm{Al}_{2} \mathrm{O}_{3}, \mathrm{Mg} \#$ of 52-68, 0.23-0.25 Ti apfu and 5.9-6.2 $\mathrm{Si}$ apfu. Mg\# decreases with decreasing melt fraction. Amphibole in Run3\#1 and Run4\#1 is magnesiohornblende; in Run4\#2 it is tschermakite (Leake et al. 1997). Amphibole-plagioclase temperatures (Holland and Blundy 1994) lie within $33^{\circ} \mathrm{C}$ of experimental temperatures for all three runs. Experimental amphibole has compositions very similar to amphiboles from cumulate xenoliths KS-15 and KS-24, but distinct from plutonic amphiboles, notably in terms of $\mathrm{Al}^{\mathrm{IV}}$ (Fig. 8 and Table 4 and A2 Supplementary), consistent with higher experimental temperatures than those calculated for plutonic xenoliths (Table 4).

Melt compositions change systematically from basaltic andesite through andesite to dacite with increasing crystallinity (Fig. 9). The effect of $a \mathrm{H}_{2} \mathrm{O}$ on plagioclase saturation imparts a strong influence on $\mathrm{Al}_{2} \mathrm{O}_{3}$ and $\mathrm{CaO}$ contents of experimental melts. At a given $\mathrm{MgO}$ content, $\mathrm{Al}_{2} \mathrm{O}_{3}$ and $\mathrm{CaO}$ in the melt increase linearly with $\mathrm{H}_{2} \mathrm{O}^{\text {melt }}$. Overall there is very close agreement between experimental melts 

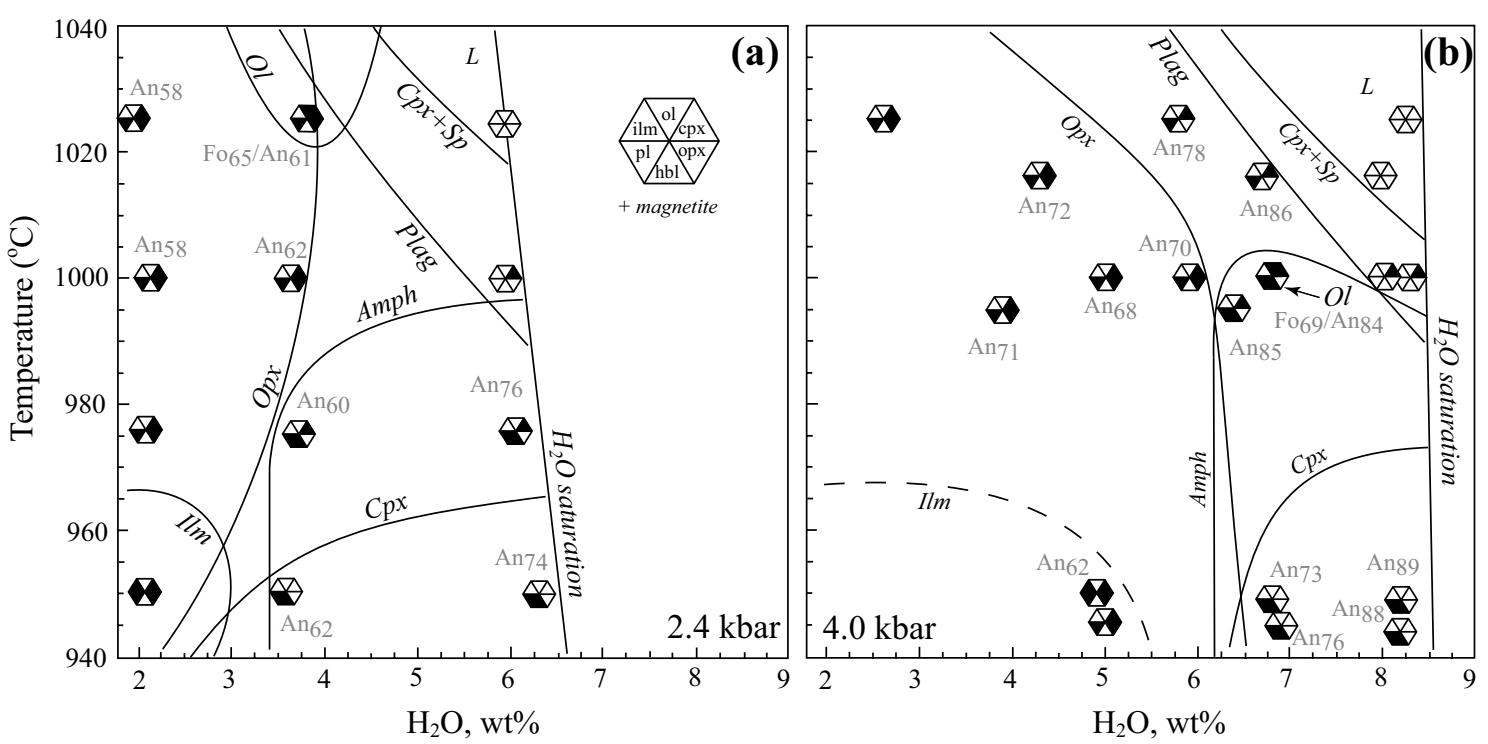

Fig. 11 Phase diagrams for the experimental series at $2.4 \mathrm{kbar}$, this study (a) and 4 kbar, Pichavant et al. (2002a) (b). Hexagons show stable mineral assemblage: $o l$ olivine, $c p x$ clinopyroxene, opx orthopyroxene, plag plagioclase, $h b l$ amphibole, $s p$ spinel, ilm ilmenite, $L$

and natural lavas and glasses with no discernible difference between 2.4 and 4 kbar experiments. There is some scatter in experimental $\mathrm{TiO}_{2}$ and $\mathrm{FeO}_{\text {tot }}$ contents both of which show some dependence on $a \mathrm{H}_{2} \mathrm{O}$, reflecting changes in oxide phase composition and proportion. As lower $a \mathrm{H}_{2} \mathrm{O}$ corresponds to lower $f \mathrm{O}_{2}$ (Table 3), this makes melt composition strongly dependent on redox state. For example, the highly oxidised experiments $(>\mathrm{NNO}+3)$ of Pichavant et al. (2002a, b) produced a magnetite-rich solid assemblage and correspondingly Fe-poor melt. The trend of decreasing $\mathrm{Na}_{2} \mathrm{O}$ at $\mathrm{MgO}$ contents $<3 \mathrm{wt} \%$ observed in lavas and natural glasses is reproduced in the experiments, although as noted above this may have its origins in $\mathrm{Na}$ loss from low melt fraction experimental glasses.

\section{Petrogenesis of St. Kitts xenoliths}

Xenoliths, lavas and melt inclusions combined with experimental results provide constraints on magmatic processes and conditions beneath St. Kitts. Thus far, we have shown that:

1. The lavas, xenoliths, and experimental assemblages have a similar mineralogy, though lavas lack amphibole phenocrysts, orthopyroxene is more common in plutonic xenoliths and lavas than in cumulate xenoliths, and olivine is rare in experiments;

2. The prevalence of zoning in minerals in plutonic xenolith and lavas testify to a more complex magmatic his- liquid. Note expansion of orthopyroxene stability at 4 kbar compared to $2.4 \mathrm{kbar}$, and intersection (multiple saturation) of amphibole, orthopyroxene and plagioclase stability fields at $4 \mathrm{kbar}$

tory than the relatively unzoned cumulate xenolith minerals;

3. Some minerals (e.g. olivine, amphibole, oxides) are compositionally similar in experiments and specific sets of natural samples (i.e. lavas, cumulates or plutonics), whereas others (plagioclases, pyroxenes) are not;

4. Intensive parameters for xenoliths and lavas are very variable, as are estimates of fluid composition $\left(\mathrm{XH}_{2} \mathrm{O}\right)$;

5. Experimental melt compositions are broadly consistent with lavas regardless of $\mathrm{P}, \mathrm{T}$ or $a \mathrm{H}_{2} \mathrm{O}$.

In this section, we draw inferences from these similarities and differences in terms of magmagenesis on St. Kitts.

\section{Liquid lines of descent}

The experimental liquids reproduce very well major element compositional variation of St. Kitts liquid line of descent (Fig. 9) as recorded by St. Kitts lavas (Toothill et al. 2007; Turner et al. 1996; and Baker 1984) and melt inclusions (Table A3 Supplementary and Toothill et al. 2007). The match between experimental liquids produced by waterrich experiments at 2.4 (this study) and 4 kbar (Pichavant et al. 2002a, b) allow us to speculate that St. Kitts lavas are consistent with being products of an oxidised (NNO to $\mathrm{NNO}+1)$ parental basaltic andesite melt with high initial $\mathrm{H}_{2} \mathrm{O}$ content and relatively low $\mathrm{CO}_{2}$. This is especially evident from $\mathrm{TiO}_{2}$ and $\mathrm{FeO}_{\text {total }}$ variations as the higher $\mathrm{TiO}_{2}$ and $\mathrm{FeO}_{\text {total }}$ contents observed for water-undersaturated runs exceed those of St. Kitts lavas. This is largely a consequence 
of $\mathrm{TiO}_{2}$ content of melts being a function of $a \mathrm{H}_{2} \mathrm{O}$ (Melekhova et al. 2015), whereas $\mathrm{FeO}_{\text {total }}$ is a function of $f \mathrm{O}_{2}$ and controlled by magnetite saturation and composition.

Alkali contents are very sensitive to melt fraction and crystallising assemblages. Extensive crystallisation of pyroxene and delayed crystallisation of amphibole in runs with $a \mathrm{H}_{2} \mathrm{O}=0.66$ led to higher total alkalis. The trend of decreasing $\mathrm{Na}_{2} \mathrm{O}$ in natural samples with $<2.5 \mathrm{wt} \% \mathrm{MgO}$ may be a consequence of partitioning of sodium into a coexisting vapour phase. Unfortunately, our experimental data, some of which are compromised by Na-loss during EMP analysis, alone do not allow us to quantify Na fluid-melt partition coefficients with any precision.

Toothill et al. (2007) demonstrated that melt inclusions in clinopyroxene, orthopyroxene, amphibole and plagioclase from lavas plot at higher $\mathrm{SiO}_{2}$ and total alkali abundances and lower $\mathrm{Al}_{2} \mathrm{O}_{3}, \mathrm{CaO}, \mathrm{TiO}_{2}$ and $\mathrm{FeO}_{\text {total }}$ than the host lavas. Cumulate-hosted melt inclusions in orthopyroxene, plagioclase, amphibole and ilmenite replicate the melt inclusion lava trends. Overall, melt inclusions in phenocrysts from lavas and cumulates show compositions consistent with them being fractionated products of basaltic andesitic magmas similar to the experimental starting composition.

Toothill et al. (2007) and Macdonald et al. (2000) identified two distinct lava trends in St. Kitts, one characterised by higher $\mathrm{Al}_{2} \mathrm{O}_{3}$ and $\mathrm{CaO}$ and the other with lower $\mathrm{Al}_{2} \mathrm{O}_{3}$ and $\mathrm{CaO}$ (Fig. 9). The two trends diverge at approximately $4.5 \mathrm{wt} \% \mathrm{MgO}$, but both lineages extend to andesitic compositions (Fig. 9). At $\sim 3 \mathrm{wt} \% \mathrm{MgO}$ the high-Al group haa $\sim 21 \mathrm{wt} \% \mathrm{Al}_{2} \mathrm{O}_{3}$, while the low-Al group has $18 \mathrm{wt} \%$ (Table 6 of Toothill et al. 2007). Macdonald et al. (2000) proposed that high- $\mathrm{Al}_{2} \mathrm{O}_{3}$ trend is the result of delayed plagioclase crystallisation, whereas enrichment in $\mathrm{CaO}$ is due to delayed clinopyroxene crystallisation. Conversely, Toothill et al. (2007) suggested that high-Al group derives from a "genuinely more aluminous [parent] magma type".

Neither set of experiments was able to reproduce the highest $\mathrm{Al}$ and $\mathrm{Ca}$ basalts reported by Toothill et al. (2007). However, at a given $\mathrm{MgO}$ content our experimental melts show a striking correlation between $\mathrm{Al}_{2} \mathrm{O}_{3}$ and $\mathrm{H}_{2} \mathrm{O}^{\text {melt }}$ owing to the ability of water to suppress plagioclase saturation and hence prevent $\mathrm{Al}$ enrichment in derivative melts (Pichavant and Macdonald 2007, their Fig. 6). Taking only experimental melts with 3.0-4.2 $\mathrm{wt} \% \mathrm{MgO}$ (on an anhydrous basis) we find the following linear relationship (concentrations expressed at $\mathrm{wt} \%$ ):

$\mathrm{Al}_{2} \mathrm{O}_{3}$ (anhyd. $)=0.50(4) \times \mathrm{H}_{2} \mathrm{O}^{\text {melt }}+15.7(3)\left(r^{2}=0.834\right)$.

Toothill et al's (2007) high-Al group would require $\mathrm{H}_{2} \mathrm{O}^{\text {melt }}$ of $10.6 \pm 1.0 \mathrm{wt} \%$ and their low-Al group $4.6 \pm 0.4 \mathrm{wt} \%$ (Fig. 12a). Thus, the primary control on the different trends observed by Toothill et al. (2007) can be ascribed simply to differences in magmatic $\mathrm{H}_{2} \mathrm{O}$ contents obviating the need to invoke more (and less) aluminous parent magma types. The two groups may originate from the same $\mathrm{H}_{2} \mathrm{O}$-rich parental magma differentiated under watersaturated conditions at different crustal depths (pressures). For a typical St. Kitts basalt with $3.5 \mathrm{wt} \% \mathrm{MgO}, 10.6 \mathrm{wt} \%$ $\mathrm{H}_{2} \mathrm{O}^{\text {melt }}$ would correspond to saturation at $5.8 \mathrm{kbar}$ and $4.6 \mathrm{wt} \% \mathrm{H}_{2} \mathrm{O}^{\text {melt }}$ to $1.6 \mathrm{kbar}$, based on calculations using MagmaSat (Ghiorso and Gualda 2015). On this basis, we propose that the different $\mathrm{Al}_{2} \mathrm{O}_{3}$ trends observed at St. Kitts represent different differentiation pressures of one or more water-rich basaltic andesite magmas that are themselves products of differentiation of more magnesian basalts generated in the mantle wedge. The proposed pressure range is consistent with that determined from cumulate (1.0-6.4 kbar) and melt inclusion (0.5-3.9 kbar) barometry. Our failure to reproduce the high-Al lava trend experimentally then stems simply from a failure to perform water-saturated experiments at sufficiently high pressure.

\section{Xenolith whole-rock chemistry}

We show also in Fig. 9 whole-rock major element compositions of plutonic and cumulate xenoliths calculated from point-counted mineral modes and mineral compositions, as well as the experimental solid residues recalculated from phase proportions and mineral compositions. As expected, experimental residues lie on the low- $\mathrm{SiO}_{2}$ extrapolation of tie-lines linking experimental melts to the relevant starting composition. In contrast, neither plutonic nor cumulate xenolith compositions overlap the experimental solids or any natural rock compositions from St. Kitts, indicating that the xenoliths are not simply crystal extracts driving the observed liquid lines of descent. Chemically the xenoliths cluster into two groups in keeping with the textural criteria used to subdivide them.

Cumulate xenoliths are significantly richer in $\mathrm{Al}_{2} \mathrm{O}_{3}$ and $\mathrm{CaO}$ and poorer in $\mathrm{Na}_{2} \mathrm{O}$ and $\mathrm{SiO}_{2}$ than experimental residues (Fig. 9). This discrepancy, which is surprising in light of the close match of the experimental liquids to St. Kitts lavas, arises because the experimental assemblages consistently have higher proportions of clinopyroxene, at the expense of amphibole, than the cumulates (Fig. 1). We consider three possible explanations for the discrepancy: in the first the cumulates are products of crystallisation of a parent magma less evolved than the basaltic andesite experimental starting material; in the second differentiation took place at pressures higher than the experiments (see above); finally, cumulate compositions have been modified by cryptic chemical interaction with migrating melts and/or fluids in the magmatic system, which converted early formed clinopyroxene into amphibole. All three explanations have merit, and will be explored more fully below. 


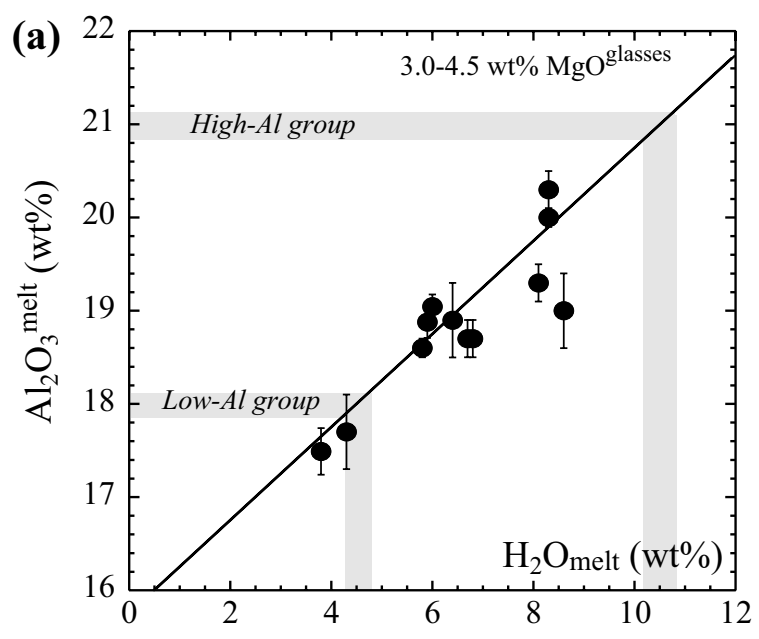

(c)

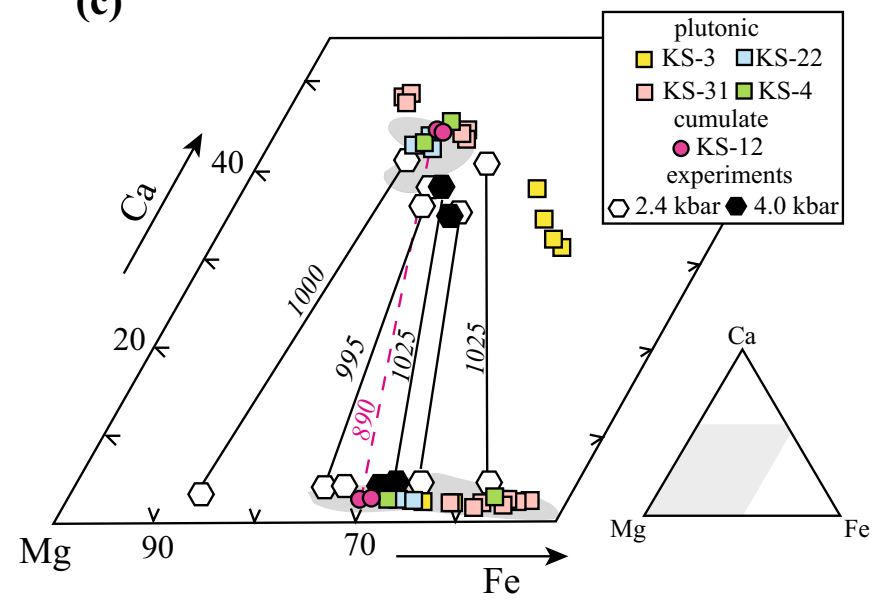

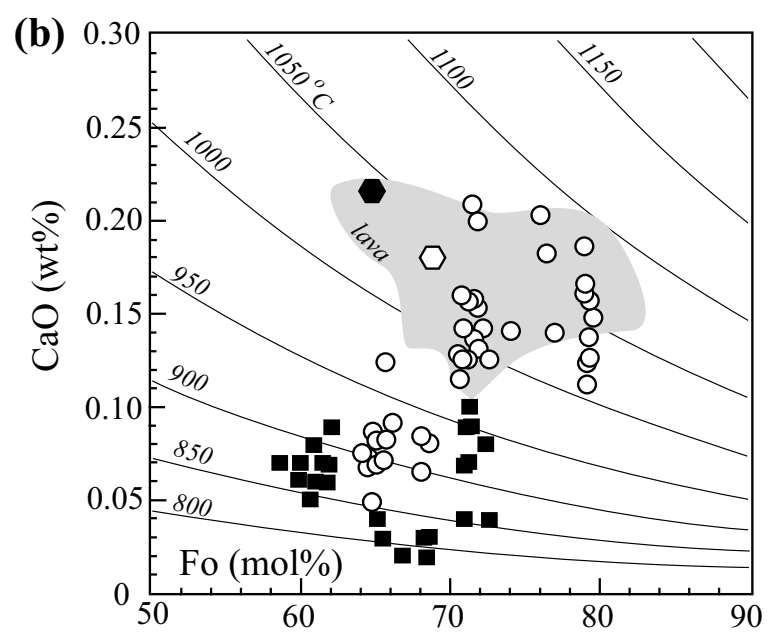

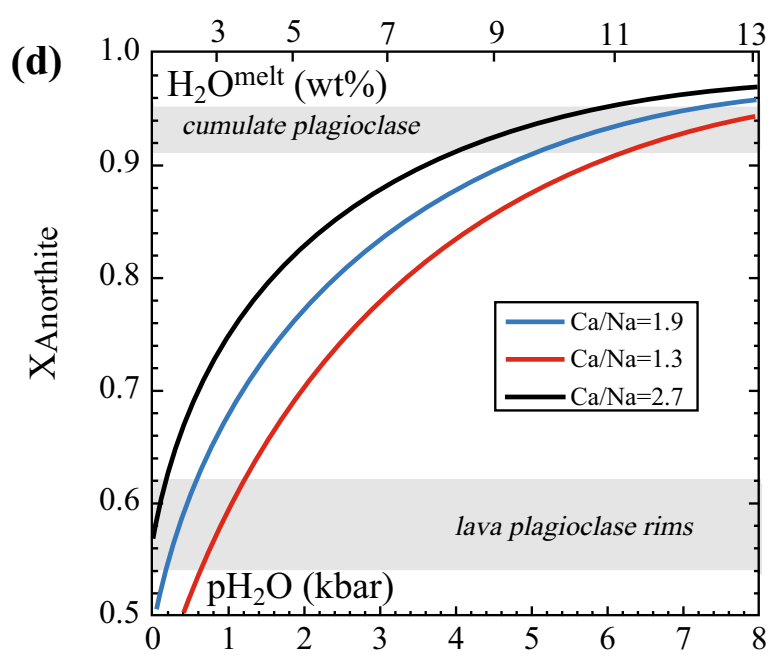

Fig. 12 Independent constraints on magmatic temperatures and $\mathrm{H}_{2} \mathrm{O}$ contents. a $\mathrm{Al}_{2} \mathrm{O}_{3}$ contents of melts as a function of dissolved $\mathrm{H}_{2} \mathrm{O}$ from experiments presented in this study filtered for $\mathrm{MgO}$ contents of 3-4.5 wt \% . Grey bars show $\mathrm{Al}_{2} \mathrm{O}_{3}$ contents of high-Al and low-Al groups of Toothill et al. (2007) at comparable MgO. b Temperatures of olivine-clinopyroxene equilibrium for experiments, xenoliths and lavas calculated using Ca-in-olivine thermometer of Shejwalkar and Coogan (2013). Symbols as in Fig. 4 with grey field to denote olivine + clinopyroxene-bearing lavas. Note the lower temperatures of plutonic xenoliths compared to lavas, experiments and most cumulate xenoliths. c Temperatures of coexisting orthopyroxene and clinopyroxene from experiments, lavas and xenoliths plotted in terms of

The plutonic xenoliths also plot outside the range defined by whole rock data of St. Kitts lavas, having lower $\mathrm{SiO}_{2}$ and total alkalis, and higher $\mathrm{Al}_{2} \mathrm{O}_{3}$ and $\mathrm{CaO}$ (Fig. 9). Consequently, the plutonic xenoliths cannot be simply solidified versions of erupted lavas. Nonetheless, the complex mineral zoning and reaction textures and diverse mineral assemblages of the plutonic xenoliths are suggestive of protracted crystallisation of magma and reaction with trapped melt. Interestingly, the bulk compositions of the plutonic xenoliths lie intermediate between the cumulate xenoliths and the
$\mathrm{Ca}, \mathrm{Mg}$ and $\mathrm{Fe}$ cations per formula unit. Tie-lines connect coexisting pyroxenes from experiments (labelled with experimental temperature). A single tie-line for a cumulate xenolith (KS-12) is shown. Note the lower temperature of lava and plutonic xenolith clinopyroxenes relative to experiments as shown by relatively high $\mathrm{Ca}$. d Calculated An content of plagioclase as a function of $\mathrm{H}_{2} \mathrm{O}$ saturation pressure $\left(\mathrm{pH}_{2} \mathrm{O}\right)$ for three different molar $\mathrm{Ca} / \mathrm{Na}$ ratios using the $\mathrm{Kd}_{\mathrm{Ca}-\mathrm{Na}}$ parameterisation in Eq. (3a). The upper axis indicates corresponding $\mathrm{H}_{2} \mathrm{O}^{\text {melt }}$ calculated for a representative basaltic andesite melt at $1000{ }^{\circ} \mathrm{C}$ using MagmaSat (Ghiorso and Gualda 2015). Grey bars denote plagioclase cores from cumulate xenoliths and phenocryst rims from lavas

lavas themselves. Thus, a simple explanation for the plutonic xenoliths is that they represent mixtures of cumulates (irrespective of their origin) with varying proportions of trapped melt of the type represented by the diverse erupted melts. The plutonic xenoliths are, in effect, fragments of magmatic mush, in which migrant melts have become trapped, driving a plethora of reactions. Protracted cooling and crystallisation of these mushes within the sub-volcanic reservoir can account for both their complex textures and their relatively low crystallisation temperatures. 


\section{Mineral compositions}

There are significant mismatches between experimental mineral assemblages and compositions, lavas and xenoliths. In this section, we explore possible explanations for these differences using compositions of phenocrysts from St. Kitts lavas (Toothill et al. 2007; Turner et al. 1996; Baker 1984), minerals from xenoliths, and experimental run products.

Olivine phenocrysts in lavas are in the range of $\mathrm{Fo}_{83-63}$ with $\mathrm{CaO}$ content $>0.13 \mathrm{wt} \%$, whereas xenolith olivines lie in the range $\mathrm{Fo}_{80-58}$, but with much more variable $\mathrm{CaO}$ (0.02-0.21 wt\%; Fig. 1a). The lowest $\mathrm{CaO}$ content olivines are found in plutonic xenoliths. Experimental olivines lie within the field defined by phenocrysts and most cumulate xenoliths, although their Fo contents $(65-70 \mathrm{~mol} \%$ Fo) are at the lower end of the natural range. Evidently some xenolith and lava olivines crystallised from magmas slightly more magnesian than our basaltic andesite starting composition.

Olivine $\mathrm{CaO}$ depends on a variety of magmatic parameters, e.g. melt composition, temperature, pressure (e.g. Jurewicz and Watson 1988; Köhler and Brey 1990; Kamenetsky et al. 2006; Mysen 2004). However, in the presence of clinopyroxene, the $\mathrm{CaO}$ content of olivine is controlled primarily by temperature (Köhler and Brey 1990; Shejwalkar and Coogan 2013). In Fig. 12b we have contoured the $\mathrm{CaO}$ versus Fo plot (Fig. 4a) for temperature using the thermometer Eq. (12) of Shejwalkar and Coogan (2013). The high $\mathrm{CaO}$ contents of olivine in experiments, lavas, and some cumulate xenoliths are consistent with crystallisation from relatively high-temperature melts $\left(1025-1125^{\circ} \mathrm{C}\right)$. Thus, phenocrystic olivines appear to be high-temperature primocrysts crystallised at or close to the liquidus. Conversely, all plutonic xenoliths and some cumulates have lower $\mathrm{CaO}$ contents consistent with re-equilibration with clinopyroxene down to temperatures as low as $800{ }^{\circ} \mathrm{C}$. This supports our contention that plutonic xenoliths (and some cumulates) have undergone cooling and solidification in the sub-volcanic reservoir. In the case of KS-3 olivine oxidation, to form orthopyroxeneoxide symplectites, may have increased olivine Fo content slightly (Johnston and Stout 1984). Oxidative increase in Fo can also account for the displacement of these olivines on the MnO-Fo plot (Fig. 4b). Thus, we suggest that the distinctive behaviour of plutonic olivine is a consequence of partial modification of their $\mathrm{Fo}$ and $\mathrm{CaO}$ contents during both cooling and oxidation.

\section{Oxides}

There is close compositional correspondence between experimental spinels and those in cumulates, although the latter extend to much higher Al\# and lower $\mathrm{Fe}^{2+} /\left(\mathrm{Mg}+\mathrm{Fe}^{2+}\right)$ (Fig. 5). The higher Al\# of cumulate spinels likely reflects the higher $\mathrm{Al}$ content of the coexisting melts, which we attribute above to elevated magmatic $\mathrm{H}_{2} \mathrm{O}$ contents suppressing plagioclase crystallisation relative to olivine and clinopyroxene. Thus, cumulate spinel testifies to crystallisation from slightly wetter and more primitive magmas than the basaltic andesite starting material. Spinel phenocrysts in lavas overlap with low Al\# end of the experimental and cumulate spinel, and provide a good match with spinel in plutonic xenoliths that lack evidence for oxidation.

Pyroxenes in cumulate and plutonic xenoliths and lavas show almost complete overlap in terms of $\mathrm{Mg \#}$ for clinopyroxene (Fig. 6a) and orthopyroxene (Fig. 6c). Experimental

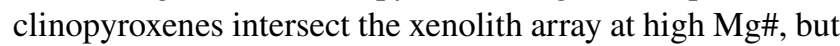
define differentiation trends to lower $\mathrm{Ca}$ and higher $\mathrm{Al}^{\mathrm{IV}}$. Experimental orthopyroxene is displaced to slightly higher $\mathrm{Ca}$ and $\mathrm{Al}^{\mathrm{IV}}$ contents. The $\mathrm{Ca}$ content of coexisting pyroxenes is buffered by the pyroxene solvus, which forms the basis of two-pyroxene thermometry (e.g. Wood and Banno 1973; Wells 1977; Lindsley 1983). Lower Ca in clinopyroxene and higher $\mathrm{Ca}$ in orthopyroxene reflect higher equilibration temperatures. Tie lines linking selected experimental and xenolith pyroxene pairs (Fig. 12c, Table 4) are consistent with $\mathrm{Kd}_{\mathrm{Fe}-\mathrm{Mg}}$ between orthopyroxene and clinopyroxene being slightly greater than one (Putirka 2008). Figure 13c indicates that the experimental pyroxene pairs are consistent with higher crystallisation temperatures $\left(1000-1025^{\circ} \mathrm{C}\right)$ than cumulates $\left(-900{ }^{\circ} \mathrm{C}\right)$, plutonics or lavas. The latter show very scattered compositions, even within a single sample (Toothill et al. 2007), that overlap with those of plutonic xenoliths, whose two-pyroxene crystallisation temperatures are in the range $770-940{ }^{\circ} \mathrm{C}$ (Table 4). The Ca-rich nature of phenocrystic clinopyroxene is therefore consistent with them being xenocrysts appropriated from cooler pockets within the magmatic mush system. A few lava clinopyroxene phenocrysts extend to lower $\mathrm{Ca}$, suggestive of high-temperature crystallisation from the host magma. However, in contrast to olivine, the majority of phenocrysts record temperatures too low to reflect an origin as true primocrysts. The higher $\mathrm{Al}^{\mathrm{IV}}$ contents of experimental pyroxenes (Fig. 6b, d) may also reflect higher crystallisation temperatures.

\section{Amphibole}

St. Kitts lavas are almost all amphibole-free, a common feature of Lesser Antilles islands with the exception of Grenada, Guadeloupe, and Saba (e.g. Arculus 1976; Westercamp and Mervoyer 1976; Baker 1980). Amphiboles in plutonic and cumulate xenoliths are texturally similar, but compositionally distinct, notably in $\mathrm{Mg} \#$ and $\mathrm{Al}^{\mathrm{IV}}$, which are proxies for melt composition (and/or $f \mathrm{O}_{2}$ ) and crystallisation temperature, respectively (Blundy and Holland 1990). Plutonic amphiboles have lower $\mathrm{Mg \#}$ and $\mathrm{Al}^{\mathrm{IV}}$ (Fig. 8a, b) than their cumulate counterparts, consistent with crystallisation to lower temperatures. Experimental amphiboles overlap the 


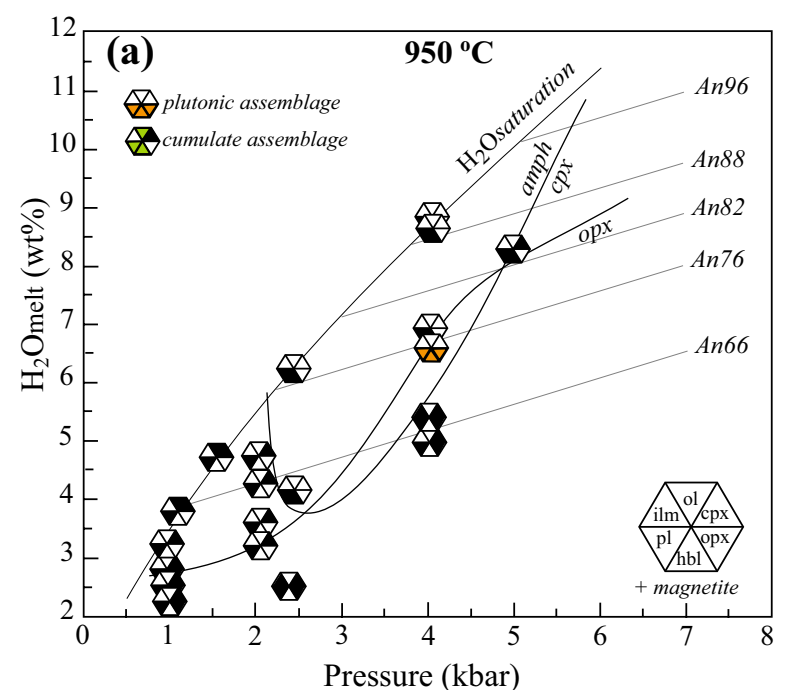

Pressure (kbar)

Fig. 13 Phase diagrams at 950 and $1000{ }^{\circ} \mathrm{C}$ plotted as functions of pressure and $\mathrm{H}_{2} \mathrm{O}^{\text {melt }}$ for experiments from this study and published data from Pichavant et al. (2002a), Almeev et al. (2013), Erdmann et al. (2016), Grove et al. (1997) and Laumonier et al. (2017). Grey solid lines with An content of plagioclase are based on weighted least-squares regressions of all plotted plagioclase-bearing experi-

low $\mathrm{Mg} \#$ and $\mathrm{Al}^{\mathrm{IV}}$ of the cumulate amphibole array. Based on textural evidence, we propose that cumulate xenolith amphiboles ( \pm calcic plagioclase) originate by percolative reaction between $\mathrm{H}_{2} \mathrm{O}$-rich melts or fluids and anhydrous, pyroxene-dominated residues, similar to those in the experiments. The hydrous fluid may also lead to the observed olivine iddingsitisation in some cumulate xenoliths. A similar metasomatic origin for cumulate amphibole was advanced by Smith (2014) for Solomon Islands xenoliths, although their lack of plagioclase likely reflects higher temperatures and/or $\mathrm{H}_{2} \mathrm{O}$ contents.

\section{Plagioclase}

Lavas and xenoliths contain highly calcic plagioclase, $\mathrm{An}_{95-54}$ and $\mathrm{An}_{97-72}$, respectively. The plutonic xenolith xenoliths span an even wider range, $\mathrm{An}_{100^{-}}{ }_{37}$, consistent with protracted cooling and crystallisation. Experimental plagioclase does not exceed $\mathrm{An}_{72}$ at $2.4 \mathrm{kbar}$, and $\mathrm{An}_{89}$ at 4 kbar. Reaching even higher An contents likely reflects crystallisation from hotter or wetter magmas and/or higher $\mathrm{Ca} / \mathrm{Na}$ magmas. For example, Sisson and Grove (1993a, b) produce $\mathrm{An}_{93}$ plagioclase in $2 \mathrm{kbar}$, water-saturated crystallisation experiments on a high-Al basalt with molar $\mathrm{Ca}$ / $\mathrm{Na}=2.9$ and $\sim 10 \mathrm{wt} \% \mathrm{MgO}$. However, these experiments are too hot $\left(1050{ }^{\circ} \mathrm{C}\right)$ for amphibole saturation and co-crystallise instead $\mathrm{Mg}$-rich olivine $\left(\mathrm{Fo}_{84}\right)$ and clinopyroxene. The challenge for St. Kitts, therefore, is how to produce Anrich plagioclases from melts that are basaltic andesites with

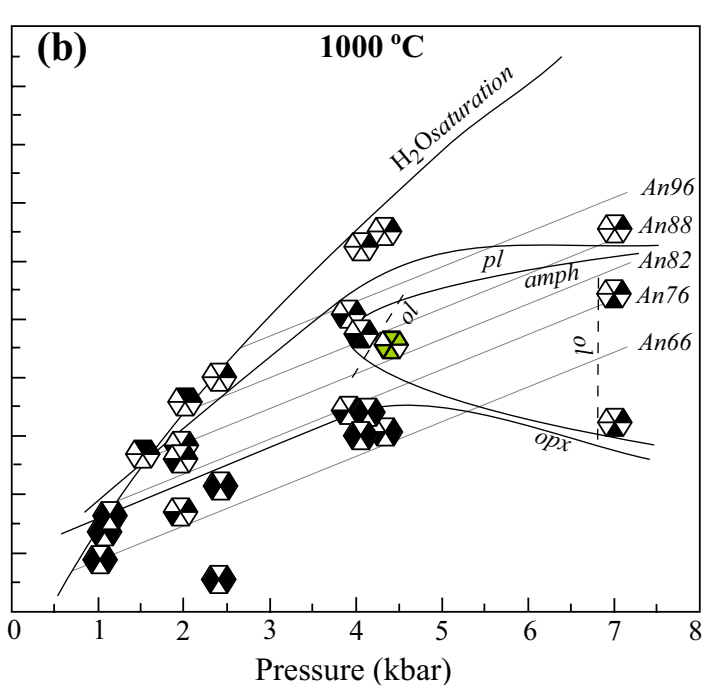

ments. $\mathrm{H}_{2} \mathrm{O}$ saturation at run conditions was calculated with MagmaSat (Ghiorso and Gualda 2015). Assemblages shown in orange and green refer to typical plutonic and cumulate xenolith assemblages, respectively, from St Kitts. Note effect of temperature on olivine and orthopyroxene stability and universal stability of clinopyroxene at $1000^{\circ} \mathrm{C}$. Mineral abbreviations as in Fig. 11

molar $\mathrm{Ca} / \mathrm{Na}$ ratio $(\leq 2.7)$ in keeping with erupted lava compositions (Turner et al. 1996; Toothill et al. 2007). In all St. Kitts cumulate xenoliths $\mathrm{An}_{>90}$ plagioclase co-crystallised with amphibole, olivine $\left(\mathrm{Fo}_{<80}\right)$ and magnetite. Significantly, in some cumulates $\mathrm{An}_{>90}$ plagioclase also co-crystallised with orthopyroxene (Fig. 1), a rare association in other Lesser Antilles xenoliths (Arculus and Wills 1980). The assemblage plagioclase $\left(\mathrm{An}_{97-85}\right)+$ orthopyroxene + clinopyroxene + olivine $\left(\mathrm{Fo}_{65-70}\right)+$ magnetite + amphibole (e.g. KS-12; Fig. 2d) is unusual for experiments performed on basaltic andesite bulk compositions (e.g. Table 3, Sisson and Grove 1993a, b; Almeev et al. 2013; Erdmann et al. 2016).

We can explore possible mechanisms for generating Anrich plagioclase by considering the exchange of $\mathrm{Ca}$ and $\mathrm{Na}$ between plagioclase and melt from the experiments. For our new experiments and those of Pichavant et al. (2002a, b) we find the following exponential relationship between $\mathrm{Kd}_{\mathrm{Ca}-\mathrm{Na}}\left(=[\mathrm{Ca} / \mathrm{Na}]_{\text {plag }} /[\mathrm{Ca} / \mathrm{Na}]_{\text {melt }}\right)$ and $\mathrm{H}_{2} \mathrm{O}^{\text {melt }}$ (Fig. A1 Supplementary):

$$
\begin{aligned}
\mathrm{Kd}_{\mathrm{Ca}-\mathrm{Na}}= & 0.485 \pm 0.051 \\
& * \exp \left\{0.294 \pm 0.019 * \mathrm{H}_{2} \mathrm{O}^{\text {melt }}\right\}\left(r^{2}=0.733\right)
\end{aligned}
$$

There is no significant temperature effect over the range of experimental temperatures studied. The slope of this relationship is similar to that reported by Sisson and Grove (1993a, b), although their data are offset to slightly higher $\mathrm{Kd}_{\mathrm{Ca}-\mathrm{Na}}$ than ours, due to differences in bulk composition. 
We emphasise that $\mathrm{Kd}_{\mathrm{Ca}-\mathrm{Na}}$ is very sensitive to melt composition (e.g. Sisson et al. 2005; Hamada and Fujii 2007), so Eq. (3a) should only be used for basaltic andesites similar to our experimental starting materials.

In Fig. 13d, we show the calculated variation in plagioclase An content for three different melt $\mathrm{Ca} / \mathrm{Na}$ contents: the two starting materials (Table 2) and the maximum molar $\mathrm{Ca} / \mathrm{Na}(=2.7)$ of any St. Kitts lava (Kit59) as reported by Toothill et al. (2007). Kit59 is a Black Rocks basalt with $\mathrm{Mg \#}=59$ and therefore in equilibrium with $\mathrm{Fo}_{82}$ olivine, the most Mg-rich observed in any St. Kitts natural sample (Fig. 4). The calculated variation in An with $\mathrm{H}_{2} \mathrm{O}^{\text {melt }}$ indicates that the highly calcic plagioclase of St. Kitts lavas and xenoliths requires magmatic $\mathrm{H}_{2} \mathrm{O}$ contents of 9-13 wt\% (5-8 kbar saturation pressure), in good agreement with the value estimated independently from lava $\mathrm{Al}_{2} \mathrm{O}_{3}$ contents. The lower An rims of lava phenocrysts would require $\mathrm{H}_{2} \mathrm{O}^{\text {melt }}$ of $<1 \mathrm{wt} \%$, consistent with them being primocrysts grown from their host magma during magma ascent and degassing.

Although high $\mathrm{H}_{2} \mathrm{O}$ melts may be responsible for very calcic plagioclase, it is worth mentioning other possibilities. For example, the An content of plagioclase can also be influenced by exchange of $\mathrm{Ca}$ and $\mathrm{Na}$ with a fluid phase, similar to that invoked for metasomatic amphibole crystallisation. Thus, the most calcic plagioclases in St. Kitts xenoliths may have a partially metasomatic origin that reflects dissolution and reprecipitation of plagioclase in the presence of migrating Na-poor melts or fluids. Conversely, Devine and Sigurdsson (1995) suggest that very calcic plagioclase $\left(\mathrm{An}_{>95}\right)$ in the Lesser Antilles is the result of crustal assimilation, although Sr isotopic data (Toothill et al. 2007) argue against this on St. Kitts.

\section{Phase assemblages}

In keeping with other Lesser Antilles islands (Arculus and Wills 1980) the diagnostic St. Kitts xenolith assemblage is calcic plagioclase + amphibole + clinopyroxene + spinel \pm orthopyroxene \pm olivine (Fig. 1a). A particular petrogenetic challenge is identifying a stability field for calcic plagioclase + orthopyroxene + amphibole \pm olivine, an assemblage that was not generated under any of the experimental conditions investigated (Fig. 11). As cumulates are snapshots of the overall differentiation process, albeit modified by metasomatic reaction, it seems likely that some part of the $\mathrm{P}-\mathrm{T}-\mathrm{H}_{2} \mathrm{O}$ evolution was not captured experimentally. To explore possible conditions under which the St. Kitts xenolith assemblages were formed, in Fig. 13 we have compiled all published experimental data on bulk compositions similar to those of St. Kitts basaltic andesite (Grove et al. 1997; Pichavant et al. 2002a, b; Almeev et al. 2013; Erdmann et al. 2016;
Laumonier et al. 2017; this study) at temperatures of 950 and $1000{ }^{\circ} \mathrm{C}$ (Fig. 13). The experimental starting compositions have $\mathrm{Mg \#} \mathrm{41-54} \mathrm{and} \mathrm{molar} \mathrm{Ca} / \mathrm{Na}$ from 2.3 to 3.8. The water saturation curve in Fig. 13 was calculated using MagmaSat (Ghiorso and Gualda 2015) for a representative basaltic andesite at the experimental temperature. At each experimental temperature we regressed plagioclase An content as a function of $\mathrm{P}$ and $\mathrm{H}_{2} \mathrm{O}^{\text {melt }}$ and contoured the plots accordingly.

Amphibole + plagioclase + clinopyroxene coexist over a wide $\mathrm{P}-\mathrm{H}_{2} \mathrm{O}^{\text {melt }}$ range (Fig. 13). Clinopyroxene is stabilised at higher temperatures; with decreasing temperature clinopyroxene and amphibole are in a reaction relationship which is terminal to clinopyroxene crystallisation at pressures of 2-5 kbar. Olivine stability is not clearly defined at either 950 or $1000^{\circ} \mathrm{C}$, although we suspect that all melts are close to olivine saturation and that for slightly higher $\mathrm{MgO}$ starting materials the olivine field would expand significantly. Orthopyroxene stability is diminished at high $\mathrm{fO}_{2}$ and high $\mathrm{H}_{2} \mathrm{O}^{\text {melt }}$ (Sisson and Grove $1993 \mathrm{~b}$ ). At $1000{ }^{\circ} \mathrm{C}$ orthopyroxene is only stable when $\mathrm{H}_{2} \mathrm{O} \leq 5 \mathrm{wt} \%$ at $4 \mathrm{kbar}$ (Fig. 13b). At $950{ }^{\circ} \mathrm{C}$ the upper pressure limit of orthopyroxene stability is unconstrained, but certainly exceeds $\mathrm{H}_{2} \mathrm{O}^{\text {melt }}=8 \mathrm{wt} \%$ and 5 kbar (Fig. 13a). The effect of $\mathrm{H}_{2} \mathrm{O}^{\text {melt }}$ on plagioclase saturation is evident at $1000{ }^{\circ} \mathrm{C}$, where plagioclase does not crystallise from melts with more than $8 \mathrm{wt} \% \mathrm{H}_{2} \mathrm{O}$, whereas at $950{ }^{\circ} \mathrm{C}$ plagioclase can crystallise from melts with almost $9 \mathrm{wt} \% \mathrm{H}_{2} \mathrm{O}$. The typical plutonic and cumulate xenolith assemblages are shown with coloured symbols. In both cases they lie at $\mathrm{P} \geq 4 \mathrm{kbar}$. However, experimental plagioclase compositions match only the more sodic rims in the natural rocks rather than the calcic cores (Fig. 1).

Although the mineral assemblages can be reproduced at $4 \mathrm{kbar}, 950-1000{ }^{\circ} \mathrm{C}$ and $\mathrm{H}_{2} \mathrm{O}^{\text {melt }} \approx 10 \mathrm{wt} \%$ the experimental plagioclase remains less calcic $\left(\mathrm{An}_{82-76}\right)$ than observed in the cumulates $\left(\mathrm{An}_{92-96}\right)$. As noted above, this reflects both the $\mathrm{Ca} / \mathrm{Na}$ ratio of the experimental starting materials, and the tendency of plagioclase An content to increase with increasing $\mathrm{P}, \mathrm{T}$ and $\mathrm{H}_{2} \mathrm{O}$ (Fig. 13). Anorthite content increases more rapidly with increasing $\mathrm{H}_{2} \mathrm{O}$ at $1000{ }^{\circ} \mathrm{C}$ compared to $950{ }^{\circ} \mathrm{C}$. The highest An contents occur at high pressures and high $\mathrm{H}_{2} \mathrm{O}^{\text {melt }}$ : $\mathrm{An}_{92-96}$ plagioclase is stable for $\mathrm{H}_{2} \mathrm{O}^{\text {melt }}$ in excess of $10 \mathrm{wt} \%$ at $950{ }^{\circ} \mathrm{C}$ and $6.5 \mathrm{wt} \%$ at $1000{ }^{\circ} \mathrm{C}$. Co-precipitation of these calcic plagioclases with orthopyroxene, as observed in many St. Kitts xenoliths, is problematic, based on the available experimental data. The closest approach is at $950{ }^{\circ} \mathrm{C}$ at $\mathrm{P}>5.5 \mathrm{kbar}$ and $\mathrm{H}_{2} \mathrm{O}^{\text {melt }} \geq 10 \mathrm{wt} \%$. Crystallisation of An-rich plagioclase is enhanced from melts with high molar $\mathrm{Ca} / \mathrm{Na}$, although the maximum value on St. Kitts, based on lavas is 2.7. Lava compositions need not necessarily represent true liquids, especially when crystals are entrained, yet this process will only serve to artificially elevate $\mathrm{Ca} / \mathrm{Na}$ ratios. Instead we propose, as inferred above 
based on plagioclase composition and lava $\mathrm{Al}_{2} \mathrm{O}_{3}$ content, that xenolith assemblages on St. Kitts require crystallisation from very $\mathrm{H}_{2} \mathrm{O}$-rich basaltic or basaltic andesite magmas.

To explore whether such wet magmas can crystallise plagioclase we have compiled existing experimental data on a broad range of hydrous arc magma compositions at pressures ranging from 1 to $12 \mathrm{kbar}$ (Fig. 14, Fig. A2 Supplimentary) (Almeev et al. 2013; Alonso-Perez et al. 2009; Beard and Lofgren 1990; Blatter and Carmichael 2001; Blatter et al. 2013; Brooker unpublished; Cawthorn et al. 1973; Eggler and Burnham 1973; Erdmann et al. 2016; Green and Ringwood 1968; Grove et al. 1997, 2003; Holloway and Burnham 1972; Laumonier et al. 2017; Melekhova et al. 2015, Müntener et al. 2001; Nandedkar et al. 2014; Panjasawatwong et al. 1995; Pichavant et al. 2002a, b; Prouteau et al. 2001; Rapp and Watson 1995; Sisson and Grove 1993a, b; Sisson et al. 2005; Winther 1990 (thesis); Yoder and Tilley 1962). The experimental starting compositions include high magnesium basalts (HMB), low magnesium basalt (LMB), high alumina basalt (HAB), basaltic andesite (BA) and andesite (A). In Fig. 14a we subdivide plagioclase-free melts from melts saturated with plagioclase or plagioclase + orthopyroxene. Plagioclase is stable in melts with as much as $20 \mathrm{wt} \%$ $\mathrm{H}_{2} \mathrm{O}$, provided temperatures are low. Our subdivision agrees well with the formulation of Almeev et al. (2012) shown as an orange line on Fig. $14 \mathrm{a}$. At $950{ }^{\circ} \mathrm{C}$ the upper $\mathrm{H}_{2} \mathrm{O}$ content of plagioclase-saturated melts is $9 \mathrm{wt} \%$, consistent with inferences from Fig. 13. Orthopyroxene coexists with plagioclase under these conditions.
In Fig. 14b, we have subdivided the experiments on the basis of their starting materials. Plagioclase stability is clearly independent of magma composition for the different magma types considered. Assemblages identical to those of St. Kitts xenoliths form at pressures of 2-9 kbar. Basaltic andesites with $8-10 \mathrm{wt} \% \mathrm{H}_{2} \mathrm{O}$ crystallise an assemblage of amphibole + plagioclase + orthopyroxene or amphibole + plagioclase + clinopyroxene at temperatures of $850-950{ }^{\circ} \mathrm{C}$ over a wide range of crustal pressures. Hydrous high alumina basalts under the same conditions crystallise the assemblage amphibole + plagioclase + olivine. Thus, the mineral assemblages of St. Kitts xenoliths are broadly consistent with crystallisation from $\mathrm{H}_{2} \mathrm{O}$-rich basalts and basaltic andesites at pressures in excess of 4 kbar.

\section{Implication for arc magmatism}

Petrological, mineralogical and experimental data provide four independent lines of evidence for differentiation of water-rich $\left(5-11 \mathrm{wt} \% \mathrm{H}_{2} \mathrm{O}\right.$ ) basaltic andesite magmas at mid-crustal depths beneath St. Kitts: highly calcic plagioclase; the mineral assemblage of cumulate xenoliths; mineral barometry; and the high-alumina group of magmas. In this section we interpret these findings in the context of a vertically extensive ("transcrustal") magmatic mush within which hydrous, basaltic magmas supplied from the underlying mantle wedge crystallise and degas, and residual melts reactively percolate upwards (Cashman et al. 2017).
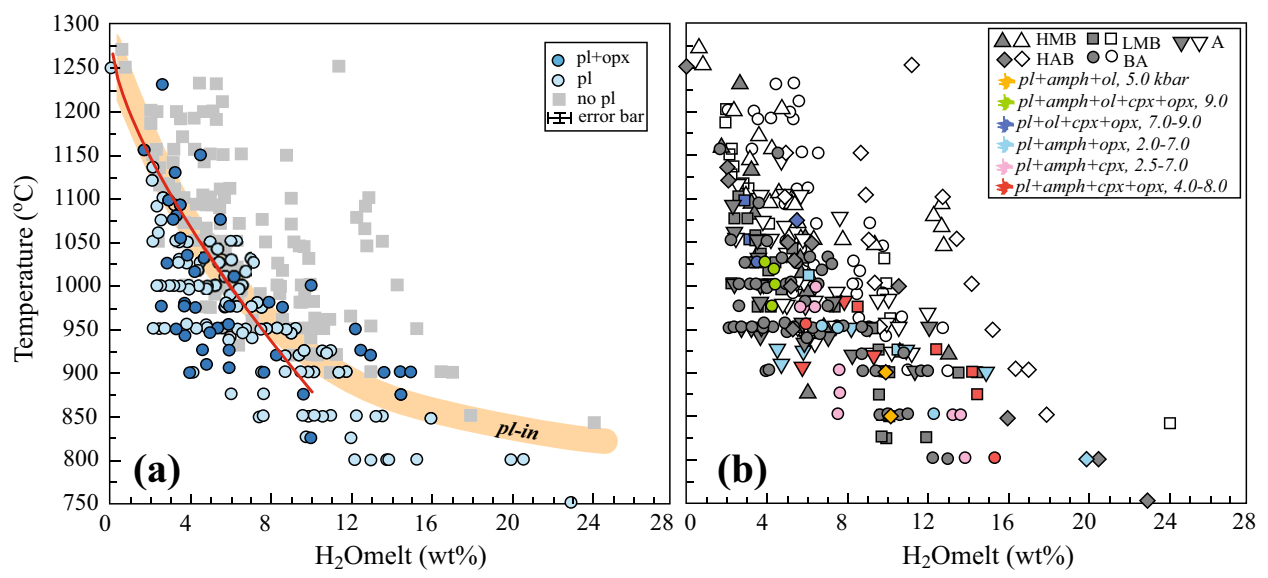

Fig. 14 Compilation of experimental data showing plagioclase stability as a function of $\mathrm{H}_{2} \mathrm{O}^{\text {melt }}$ and temperature for pressures between 0.5 and $12 \mathrm{kbar}$ in the following bulk compositions: high magnesium basalt (HMB), low magnesium basalt (LMB), high alumina basalt (HAB), basaltic andesite (BA) and andesite (A). When $\mathrm{H}_{2} \mathrm{O}$ concentration is not reported MagmaSat was used to estimate $\mathrm{H}_{2} \mathrm{O}^{\text {melt }}$ at the run conditions. A representative 1 s.d. uncertainty is shown. a Plagioclase and orthopyroxene stability field. The plagioclase-in ( $p l-i n)$ line demonstrates extent of plagioclase stability in melts with $\mathrm{H}_{2} \mathrm{O}$ contents up to $24 \mathrm{wt} \%$. b Experimental data shown in terms of the starting compositions (symbols) and run product assemblages and corresponding pressure in kbar (colours). Filled symbols denote the presence of plagioclase; open symbols are plagioclase-free. Some typical cumulate and plutonic xenolith assemblages from St Kitts (Table 1) are illustrated by different colours: orange-KS8, KS21, KS15; dark blue-KS12; pink-KS24; red-KS4; light blue-KS6. Solid orange line in (a) is plagioclase-in boundary of Almeev et al. (2012) 
The elevated magmatic water contents are consistent with findings at a number of other arc volcanoes. Edmonds et al. (2016) propose 6-9 wt\% $\mathrm{H}_{2} \mathrm{O}$ in andesites from Soufrière Hills Volcano, Montserrat, on the basis of $\mathrm{H}_{2} \mathrm{O}$ dissolved in orthopyroxene phenocrysts. Grove et al. (2003) proposed $\geq 11 \mathrm{wt} \% \mathrm{H}_{2} \mathrm{O}$ in some primitive magmas from Mt. Shasta, Cascades, on the basis of amphibole chemistry and melt inclusions. Laumonnier et al. (2017) used a combination of geophysical and petrological evidence to argue that the andesitic partial melt contained within the AltiplanoPuna Magma Body contains 9-11 wt $\% \mathrm{H}_{2} \mathrm{O}$.

Our proposal for elevated $\mathrm{H}_{2} \mathrm{O}$ contents in St. Kitts basaltic andesites requires proportionately higher $\mathrm{H}_{2} \mathrm{O}$ in parental basalts. Experimental data (e.g. Nandedkar et al. 2014; Melekhova et al. 2015) show that basaltic andesites can be generated from mantle-derived MgO-rich basalts by approximately 40-60 wt \% crystallisation, predominantly of anhydrous mafic silicates. In that case basaltic andesite $\mathrm{H}_{2} \mathrm{O}$ contents of $\leq 11 \mathrm{wt} \%$ would equate to $\leq 6.6 \mathrm{wt} \% \mathrm{H}_{2} \mathrm{O}$ in the parental basalt. This value is within the range $(\leq 7.2 \mathrm{wt} \%)$ of $\mathrm{H}_{2} \mathrm{O}$ contents of olivine-hosted basaltic melt inclusions from a broad selection of subduction zones (Plank et al 2013), for which the mean $\mathrm{H}_{2} \mathrm{O}$ content is $3.9 \pm 0.5 \mathrm{wt} \%$. Basaltic andesite $\mathrm{H}_{2} \mathrm{O}$ contents of $>7 \mathrm{wt} \%$ requires that differentiation of their parent magmas occurs at sufficient depth in the crust to hold $\mathrm{H}_{2} \mathrm{O}$ in solution. In the case of St. Kitts basaltic andesites $\leq 11 \mathrm{wt} \% \mathrm{H}_{2} \mathrm{O}$ corresponds to pressures of $\leq 6.5 \mathrm{kbar}\left(\right.$ at $1050{ }^{\circ} \mathrm{C}$ ). For a mean crustal density of $2660 \mathrm{~kg} / \mathrm{m}^{3}$ for the Lesser Antilles arc (Christeson et al. 2008 ) this equates to lower crustal depths of $\leq 25 \mathrm{~km}$.

The basaltic andesite starting materials from our experiments have been shown to provide a good match to parental melts for some St. Kitts xenoliths, although slightly higher $\mathrm{Mg \#}$ parents are required to generate the observed olivine Fo contents. However, adding a small amount of olivine to the basaltic andesites will not render them sufficiently magnesian to be in equilibrium with mantle peridotite. Mantle-derived magnesian basalts would need to crystallise 40-60 wt\% to generate the low-magnesium basalts or basaltic andesites found on St. Kitts. The crystalline residues from this differentiation would be olivine + clinopyroxene + spinel (Müntener et al. 2001; Müntener and Ulmer 2006; Nandedkar et al. 2014; Melekhova et al. 2015) with little or no plagioclase or amphibole. We suggest that cumulate rocks with this mineralogy underlie the St. Kitts magmatic system, at depths greater than $25 \mathrm{~km}$. It is worth noting that the density of seismic velocities of such ultramafic cumulate rocks would make them very hard to distinguish geophysically from mantle rocks (Müntener and Ulmer 2006). It is perhaps for this reason that the Moho discontinuity is not clearly resolved beneath the Lesser Antilles (Christeson et al. 2008; Kopp et al. 2011).
We propose that water-rich, relatively oxidised $(\mathrm{NNO}+1$ to $\mathrm{NNO}+2$ ) low-Mg basalts and basalt andesites generated by olivine + clinopyroxene + spinel fractionation in the deep crust ascend to $18-25 \mathrm{~km}$ where they begin to differentiate, producing the xenolith varieties observed on St. Kitts. Elevated $\mathrm{H}_{2} \mathrm{O}$ contents are required to generate the calcic plagioclase that is diagnostic of xenoliths on St. Kitts and elsewhere in the Lesser Antilles. St. Kitts xenoliths record snapshots of this polybaric differentiation process, whereas erupted magmas represent the integrated products, modified by migration through the thick crystal mush pile. Our experiments show that most of the lavas erupted on St. Kitts can be generated at pressures of 2.4-4 kbar, with $\mathrm{H}_{2} \mathrm{O}$ contents down to 2-6 wt\%, i.e. significantly lower than those inferred for the basaltic andesite parents. The tendency for erupted magmas to match low-pressure experimental data is consistent with the vertically extensive mush concept; as melts migrate upwards they will continually equilibrate with crystals in the mush. Their apparent equilibration pressure will correspond to the top of the mush, even though differentiation began at much greater depths. Only occasionally do melts bypass the mush column and so preserve their highpressure chemistry upon eruption; the Al-rich series on St. Kitts is one such example.

We propose that the hallmark of magmas generated in transcrustal mushes will be multiple saturation with four or more of the following mineral phases: olivine, clinopyroxene, orthopyroxene, amphibole, plagioclase, and spinel. Conversely, the crystals represent snapshots of the entire, polybaric differentiation process and are, therefore, much more sensitive to local conditions. As basaltic andesite or low-Mg basalts magmas entering the base of the mush are $\mathrm{H}_{2} \mathrm{O}$ (and possibly $\mathrm{CO}_{2}$ ) rich, so the melts leaving the top of the mush will be volatile-saturated. Once a significant mass of mush is established in the arc crust, it tends to buffer melt compositions, becoming relative immune to new additions of slightly different composition. We suggest that the ability of the mush to buffer melts along polybaric, multi-phase cotectics gives rise to relatively well-defined liquid lines of descent. Recent experimental studies of a Mount St Helens dacite by Blatter et al. (2017) are a case in point; they find multiple saturation with amphibole-plagioclase-orthopyroxene-clinopyroxene-oxide at $4 \mathrm{kbar}$. The abundance of amphibole within the crystal mush column drives amphibole saturation with attendant trace element signatures, despite the paucity of amphibole phenocrysts in many erupted arc magmas (Davidson et al 2007). There is abundant textural evidence in St. Kitts xenoliths for percolative, reactive flow of hydrous fluids/melts, including reactions of early-formed clinopyroxene to amphibole, mineral zoning, poikilitic crystals and disequilibrium textures. The consequences of percolative reactive flow may be especially complicated for trace 
elements, as observed in xenoliths from Martinique (Cooper et al. 2017).

As melts ascend through transcrustal mush they will exsolve volatiles and interact with pre-existing crystals. Interactions include metasomatic reactions, such as those observed in plutonic xenoliths from St. Kitts. Ascending melts may also rip up mush fragments, either as crystal clots or as disaggregated xenocrysts. We have demonstrated that calcic plagioclase, spinel and pyroxene phenocrysts in St. Kitts lavas are typically xenocrystic (or more accurately, antecrystic) in origin. This crystal cargo may be significantly overgrown or overprinted by liquidus phases that crystallise from the host magma as it leaves the top of the mush and ascends to the surface. Olivine phenocrysts and intermediate plagioclase rims in St. Kitts lavas are examples of low-pressure primocrysts. In arc magmas, unraveling the relative proportions of xenocrysts, antecrysts and primocrysts is notoriously difficult.

The release of exsolving fluids from ascending magmas within the mush may also lead to reactions with preexisting crystals, including dissolution and reprecipitation, leaching of fluid-mobile elements (such as $\mathrm{Na}$ ) and production of hydrous mineral phases (e.g. Smith 2014). Because of their different densities, it is likely that fluid and melt movement are decoupled (Christopher et al. 2015). The compositions of the exsolved fluid changes with depth, being more $\mathrm{CO}_{2}$ (and $\mathrm{SO}_{2}$ ) rich at higher pressures. Percolation of fluids from the top of the mush that have been released across a considerable vertical depth range may explain the apparent flushing of shallow-stored magmas with $\mathrm{CO}_{2}$. There is widespread evidence of this in melt inclusions from arc volcanoes (e.g. Blundy et al. 2010) as well as in some interstitial glasses from St. Kitts xenoliths. Discharge of $\mathrm{SO}_{2}$-rich fluids from the top of a transcrustal mush may play an important role in hydrothermal mineralization (Mavrogenes and Blundy 2017).

The process of melt migration through the transcrustal magmatic mush can operate on two different timescales. Slow, percolative flow can account for many of the observed xenolith textures and the tendency for erupted magmas to be chemically buffered. However, the presence of xenoliths containing volatile-rich melt inclusions indicates that a more rapid process may also operate, whereby melts disaggregate and entrain mush shortly before eruption. Christopher et al. (2015) suggest that large-scale gravitational destabilisation of the mush is one means to rapidly aggregate and release magmas to shallow levels. Conditions under which mushes become gravitational unstable, and the timescales of consequent magma ascent, are rich areas for further study.

Acknowledgements This research was supported by grants from ERC (“CRITMAG") and NERC (NE/N001966/1). JB acknowledges a Wolfson Research Merit Award from the Royal Society. We thank R. Hinton and C.J. de Hoog for assistance with SIMS analysis and S. Kearns for help with EPMA. The work has benefitted from useful discussions with G. Cooper, S. Sparks, L. Ziberna and K. Cashman. We thank P. Ulmer and R. Almeev for insightful comments and suggestions that improved the manuscript and $\mathrm{O}$. Müntener for editorial handling.

Open Access This article is distributed under the terms of the Creative Commons Attribution 4.0 International License (http://creativecommons.org/licenses/by/4.0/), which permits unrestricted use, distribution, and reproduction in any medium, provided you give appropriate credit to the original author(s) and the source, provide a link to the Creative Commons license, and indicate if changes were made.

\section{References}

Almeev RR, Holtz F, Koepke J, Para F (2012) Experimental calibration of the effect of $\mathrm{H}_{2} \mathrm{O}$ on plagioclase crystallization in basaltic melt at $200 \mathrm{MPa}$. Am Mineral 97:1234-1240

Almeev RR, Ariskin AA, Kimura J-I, Barmina GS (2013) The role of polybaric crystallization in genesis of andesitic magmas: phase equilibria simulations of the Bezymianny volcanic subseries. J Volcanol Geotherm Res 263:182-192. https://doi. org/10.1016/j.jvolgeores.2013.01.004

Alonso-Perez R, Muntener O, Ulmer P (2009) Igneous garnet and amphibole fractionation in the roots of island arcs: experimental constraints on andesitic liquids. Contrib Mineral Petrol 157(4):541-558

Andersen DJ, Lindsley DH (1985) New (and final!) models for the Ti-magnetite/ilmenite geothermometer and oxygen barometer. Abstract AGU 1985 Spring Meeting Eos Transactions American Geophysical Union 66(11)

Arculus RJ (1976) Geology and geochemistry of the alkali basaltandesite association of Grenada, Lesser Antilles island arc. Geol Soc Am Bull 87:612-624

Arculus RJ, Wills KJA (1980) The petrology of plutonic blocks and inclusions from the Lesser Antilles Island Arc. J Petrol 21(4):743-799

Baker PE (1968) Petrology of Mt. Misery volcano, St. Kitts, West Indies. Lithos 1(2):124-150

Baker PE (1980) Geology and geochemistry of the mansion pyroclastic fall succession, St. Kitts. Bull Volcanol 43(2):303-310

Baker PE (1984) Geochemical evolution of St Kitts and Montserrat, Lesser Antilles. J Geol Soc 141(3):401-411

Beard JS, Lofgren GE (1990) Dehydration melting and water-saturated melting of basaltic and andesitic greenstones and amphibolites at 1, 3, and 6-9 kb. J Petrol 32(2):365-401

Blatter DL, Carmichael ISE (2001) Hydrous phase equilibria of a Mexican high-silica andesite: a candidate for a mantle origin? Geochim Cosmochim Acta 65(21):4043-4065

Blatter DL, Sisson TW, Hankins WB (2013) Crystallization of oxidized, moderately hydrous arc basalt at mid- to lower-crustal pressures: implications for andesite genesis. Contrib Mineral Petrol 166(3):861-886

Blatter DL, Sisson TW, Hankins WB (2017) Voluminous arc dacites as amphibole reaction-boundary liquids. Contrib Mineral Petrol 172(5). https://doi.org/10.1007/s00410-017-1340-6

Blundy JD, Holland TJB (1990) Calcic amphibole equilibria and a new amphibole-plagioclase geothermometer. Contrib Mineral Petrol 104(2):208-224

Blundy J, Cashman K, Berlo K (2008) Evolving magma storage conditions beneath Mount St. Helens inferred from chemical variations in melt inclusions from the 1980-1986 and current eruptions. In: 
Sherrod DR, Scott WE, Stauffer PH (eds) A volcano rekindled; the renewed eruption of Mount St Helens, 2004-2006, vol 1750. U.S. Geological Survey Professional Paper, pp 755-790

Blundy J, Cashman KV, Rust A, Witham F (2010) A case for $\mathrm{CO}_{2}$-rich arc magmas. Earth Planet Sci Lett 290(3-4):289-301. https://doi.org/10.1016/j.epsl.2009.12.013

Botcharnikov RE, Behrens H, Holtz F (2006) Solubility and speciation of C-O-H fluids in andesitic melt at $T=1100-1300{ }^{\circ} \mathrm{C}$ and $P=200$ and $500 \mathrm{MPa}$. Chem Geol 229(1-3):125-143. https://doi.org/10.1016/j.chemgeo.2006.01.016

British Geological Society Rock Classification - Gillespie MR, Style MT (1999) BGS Rock Classification Scheme. In: Classification of igneous rocks. British Geological Survey Research Report, vol 1, 2nd edn. RR 99-06

Burnham CW (1979) The importance of volatile constituents. In: Yoder HS (ed) The evolution of igneous rocks. Princeton University Press, Princeton, pp 439-482

Cashman KV, Sparks RSJ, Blundy JD (2017) Vertically extensive and unstable magmatic systems: a unified view of igneous processes. Science 355:1280. https://doi.org/10.1126/0.1126/ science.aag3055

Cawthorn RG, Grant EB, Arculus RJ (1973) A petrogenetic model for the origin of the calc-alkaline suite of Grenada, Lesser Antilles. J Petrol 14(2):327-337

Costa F, Dungan MA, Singer BS (2002) Hornblende- and phlogopitebearing gabbroic xenolith from Volcan San Pedro $\left(36^{\circ} \mathrm{S}\right)$, Chilean Andes: evidence for melt and fluid migration and reactions in subduction-related plutons. J Petrol 43(2):219-241

Christeson G, Mann P, Escalona A, Aitken TJ (2008) Crustal structure of the Caribbean-northeastern South America arc-continent collision zone. J Geophys Res 113:B08104

Christopher TE, Blundy J, Cashman K, Cole P, Edmonds M, Smith PJ, Sparks RSJ, Stinton A (2015) Crustal-scale degassing due to magma system destabilization and magma-gas decoupling at Soufrie`re Hills Volcano, Montserrat. Geochem Geophys Geosyst 16(9):2797-2811

Conrad WK, Kay SM, Kay RW (1983) Magma mixing in the Aleutian arc: evidence from cognate inclusions and composite xenolith. J Volcanol Geotherm Res 18(1-4):279-295

Cooper GF, Davidson JP, Blundy JD (2017) Plutonic xenoliths from Martinique, Lesser Antilles: evidence for open system processes and reactive melt flow in island arc crust. Contrib Mineral Petrol 171(10). https://doi.org/10.1007/ s00410-016-1299-8

Davidson J, Turner S, Handley H, Macpherson C, Dosseto A (2007) Amphibole "sponge" in arc crust? Geology 35(9):787-790

Deer WA, Howie RA, Zussman J (1992) An introduction to the rockforming minerals, vol 696. Longman, London

Devine JD, Sigurdsson H (1995) Petrology and eruption styles of Kick'em-Jenny submarine volcano, Lesser Antilles island arc. J Volcanol Geotherm Res 69(1-2):35-58

Droop GTR (1987) A general equation for estimating $\mathrm{Fe}^{3}+$ concentrations in ferromagnesian silicates and oxides from microprobe analyses, using stoichiometric criteria. Mineral Mag 51(361):431-435

Ducea MN, Saleeby JB (1998) The age and origin of a thick magicultramafic keel from beneath the Sierra Nevada batholith. Contrib Mineral Petrol 133:169-185

Dungan MA, Davidson J (2004) Partial assimilative recycling of the mafic plutonic roots of arc volcanoes: an example from the Chilean Andes. Geology 32(9):773-776

Earle KW (1925) Reports on the geology of St. Kitts-Nevis, BIfr. land on the geology of Anguilla. In: BIVI Crown Agents for the Colonies, vol., London, p 50

Edmonds M, Kohn SC, Hauri EH, Humphreys MCS, Cassidy M (2016) Extensive, water-rich magma reservoir beneath southern Montserrat. Lithos 252-253:216-233. https://doi. org/10.1016/j.lithos.2016.02.026

Eggler DH, Burnham WC (1973) Crystallization and fractionation trends in the system andesite $-\mathrm{H}_{2} \mathrm{O}-\mathrm{CO}_{2}-\mathrm{O}_{2}$ at pressures to $10 \mathrm{~Kb}$. Geol Soc Am Bull 84(8):2517. https://doi. org/10.1130/0016-7606(1973)84<2517:caftit>2.0.co;2

Erdmann S, Martel C, Pichavant M, Bourdier J-L, Champallier R, Komorowski J-C, Cholik N (2016) Constraints from phase equilibrium experiments on pre-eruptive storage conditions in mixed magma systems: a case study on crystal-rich basaltic andesites from Mount Merapi, Indonesia. J Petrol 57(3):535-560

Fels G (1903) Ein Anorthitauswurfling von der Insel St Christopher. Z für Krist Cryst Mater 37:450-460

Ghiorso MS, Evans BW (2008) Thermodynamics of rhombohedral oxide solid solutions and a revision of the Fe-Ti two-oxide geothermometer and oxygen-barometer. Am J Sci 308(11):9571039. https://doi.org/10.2475/09.2008.01

Ghiorso MS, Gualda GAR (2015) $\mathrm{An}_{2} \mathrm{O}-\mathrm{CO}_{2}$ mixed fluid saturation model compatible with rhyolite-MELTS. Contrib Miner Petrol 169:53. https://doi.org/10.1007/s00410-015-1141-8

Green TH, Ringwood AE (1968) Genesis of the calc-alkaline igneous rock suite. Contrib Mineral Petrol 18:105-162

Grove TL, Donnelly-Nolan JM, Housh T (1997) Magmatic processes that generated the rhyolite of Glass Mountain, Medicine Lake volcano, N. California. Contrib Mineral Petrol 127:205-223

Grove TL, Elkins-Tanton LT, Parman SW, Chatterjee N, Muntener O, Gaetani GA (2003) Fractional crystallization and mantle-melting controls on calc-alkaline differentiation trends. Contrib Mineral Petrol 145:515-533

Haase KM, Lima S, Krumm S, Garbe-Schönberg D (2014) The magmatic evolution of young island arc crust observed in gabbroic to tonalitic xenoliths from Raoul Island, Kermadec Island Arc. Lithos 210-211:199-208. https://doi.org/10.1016/j. lithos.2014.10.005

Hamada M, Fujii T (2007) $\mathrm{H}_{2} \mathrm{O}$-rich island arc low-K tholeiite magma inferred from Ca-rich plagioclase-melt inclusion equilibria. Geochem J 41(6):437-461

Harrison TM, Watson EB (1983) The bahavior of apatite during crustal anatexis: equlibrium and kenetic considerations. Geochim Cosmochim Acta 48:1467-1477

Hickey-Vargas R, Abdollahi MJ, Parada MA, Lopez-Escobar L, Frey FA (1995) Crustal xenoliths from Calbuco Volcano, Andean Southern Volcanic Zone: implications for crustal composition and magma-crust interaction. Contrib Mineral Petrol 119(4):331-344

Holland T, Blundy J (1994) Non-ideal interactions in calcic amphiboles and their bearing on amphibole-plagioclase thermometry. Contrib Mineral Petrol 116:433-447

Holloway JR, Burnham CW (1972) Melting relations of basalt with equilibrium water pressure less than total pressure. J Petrol 13(1): $1-29$

Johnston AD, Stout JH (1984) Development of orthopyroxene-Fe/Mg ferrite symplectites by continuous olivine oxidation. Contrib Mineral Petrol 88:196-202

Jurewicz AJG, Watson EB (1988) Cations in olivine, Part 2: diffusion in olivine xenocrysts, with applications to petrology and mineral physics. Contrib Mineral Petrol 99:186-201

Kamenetsky VS, Elburg M, Arculus R, Thomas R (2006) Magmatic origin of low-Ca olivine in subduction-related magmas: coexistence of contrasting magmas. Chem Geol 233(3-4):346-357. https://doi.org/10.1016/j.chemgeo.2006.03.010

Kay SM, Kay RW (1985) Role of crystal cumulates and the oceanic crust in the formation of the lower crust of the Aleutian arc. Geology 13(7):461-464 
Kiddle EJ, Edwards BR, Loughlin SC, Petterson M, Sparks RSJ (2010) Crustal structure beneath Montserrat, Lesser Antilles, constrained by xenoliths, seismic velocity structure and petrology. Geophys Res Lett 37:11

Köhler TP, Brey GP (1990) Calcium exchange between olivine and clinopyroxene calibrated as a geothermobarometer for natural peridotites from 2 to $60 \mathrm{~kb}$ with applications. Geochim Cosmochim Acta 54:2375-2388

Kopp H, Weinzierl W, Becel A, Charvis P, Evain M, Flueh ER, Gailler A, Galve A, Hirn A, Kandilarov A, Klaeschen D, Laigle M, Papenberg C, Planert L, Roux E (2011) Deep structure of the central Lesser Antilles Island Arc: relevance for the formation of continental crust. Earth Planet Sci Lett 304(1-2):121-134. https://doi.org/10.1016/j.eps1.2011.01.024

Laumonier M, Gaillard F, Muir D, Blundy J, Unsworth M (2017) Giant magmatic water reservoirs at mid-crustal depth inferred from electrical conductivity and the growth of the continental crust. Earth Planet Sci Lett 457:173-180. https://doi.org/10.1016/j. epsl.2016.10.023

Leake BE, Woolley AR, Arps CES, Birch WD, Gilbert MC, Grice JD, Hawthorne FC, Kato A, Kisch HJ, Krivovichev VG, Linthout K, Laird J, Mandarino JA, Maresch WV, Nickel EH, Rock NMS, Shumacher JC, Smith DC, Stephrnson NCN, Ungaretti L, Whittaker EJW, Youzhi G (1997) Nomenclature of amphiboles: report of the subcommittee on amphiboles of the international mineralogical association, commission on new minerals and mineral names. Can Mineral 35:219-246

Leake BE, Woolley AR, Birch WD, Burke EAJ, Ferraris G, Grice JD, Hawthorne FC, Kisch HJ, Krivovichev VG, Shumacher JC, Stephrnson NCN, Whittaker EJW (2004) Nomenclature of amphiboles: additions and revisions to the International Mineralogical Association's amphibole nomenclature. Am Mineral 89:883-887

Lesne P, Kohn SC, Blundy J, Witham F, Botcharnicov RE, Behrens $H$ (2011) Experimental simulation of closed-system degassing in the system Basalt- $\mathrm{H}_{2} \mathrm{O}-\mathrm{CO}_{2}-\mathrm{S}-\mathrm{Cl}$. J Petrol 52(9):1737-1762

Leuthold J, Müntener O, Baumgartner LP, Putlitz V (2014) Petrological constraints on the recycling of mafic crystal mushes and intrusion of braided sills in the Torres del Paine Mafic Complex (Patagonia). J Petrol 55(5):917-949

Lewis JF (1973) Mineralogy of the egected plutonic blocks of the Soufriere volcano St. Vincent: olivine, pyroxene, amphibole and Magnetite paragenesis. Contrib Mineral Petrol 38:197-220

Lindsley DH (1983) Pyroxene thermometry. Am Miner 68:477-493

Macdonald R, Hawkeswoorth CJ, Heath E (2000) The Lesser Antilles volcanic chain: a study in arc magmatism. Earth Sci Rev 49:1-76

Maury RC, Westercamp D (1990) Geology of the Lesser Antilles. In: Boulder CO (ed) The geology of North America, vol the Caribbean Region. Geological Society of America, Boulder, pp 141-166

Mavrogenes J, Blundy J (2017) Crustal sequestration of magmatic sulfur dioxide. Geology 45(3):211-214. https://doi.org/10.1130/ g38555.1

McLeod CL, Davidson JP, Nowell GM, de Silva SL, Schmitt AK (2013) Characterizing the continental basement of the Central Andes: constraints from Bolivian crustal xenoliths. Geol Soc Am Bull 125(5-6):985-997. https://doi.org/10.1130/b30721.1

Melekhova E, Blundy J, Robertson R, Humphreys MCS (2015) Experimental evidence for polybaric differentiation of primitive arc basalt beneath St. Vincent, Lesser Antilles. J Petrol 56(1):161-192

Morse SA (1976) The lever rule with fractional crystallisation and fusion. Am J Sci 276:330-346
Müntener O, Ulmer P (2006) Experimentally derived high-pressure cumulates from hydrous arc magmas and consequences for the seismic velocity structure of lower arc crust. Geophys Res Lett 33:L21308. https://doi.org/10.1029/2006GL027629

Müntener O, Kelemen PB, Grove TL (2001) The role of $\mathrm{H}_{2} \mathrm{O}$ during crystallization of primitive arc magmas under uppermost mantle conditions and genesis of igneous pyroxenites: an experimental study. Contrib Mineral Petrol 141:643-658

Mysen BO (2004) Element partitioning between minerals and melt, melt composition, and melt structure. Chem Geol 213:1-16. https://doi.org/10.1016/j.chemgeo.2004.08.028

Nandedkar RH, Ulmer P, Müntener O (2014) Fractional crystallization of primitive, hydrous arc magmas: an experimental study at $0.7 \mathrm{GPa}$. Contrib Mineral Petrol 167:1015. https://doi. org/10.1007/s00410-014-1015-5)

Nekvasil H, Lindsley DH, DiFrancesco N, Catalano T, Coraor AE, Charlier B (2015) Uncommon behavior of plagioclase and the ancient lunar crust. Geophys Res Lett. https://doi. org/10.1002/2015GL066726

Newman S, Lowenstern JB (2002) VolatileCalc: a silicate melt- $\mathrm{H}_{2} \mathrm{O}$ $\mathrm{CO}_{2}$ solution model written in Visual Basic for excel. Comput Geosci 28(5):597-604

Panjasawatwong Y, Danyushevsky LV, Crawford AJ, Harris KL (1995) An experimental study of the effects of melt composition on plagioclase-melt equilibria at 5 and 10 kbar: implications for the origin of magmatic high-An plagioclase. Contrib Mineral Petrol 118:420-432

Pichavant M, Macdonald R (2007) Crystallization of primitive basaltic magmas at crustal pressures and genesis of the calc-alkaline igneous suite: experimental evidence from St Vincent, Lesser Antilles arc. Contrib Mineral Petrol 154(5):535-558

Pichavant M, Martel C, J-1 Bourdier, Scaillet B (2002a) Physical conditions, structure, and dynamics of a zoned magma chamber Mount Pele'e (Martinique, Lesser Antilles Arc). J Geophys Res. https:// doi.org/10.1029/2001JB000315

Pichavant M, Mysen BO, Macdonald R (2002b) Source and $\mathrm{H}_{2} \mathrm{O}$ content of high- $\mathrm{MgO}$ magmas in island arc settings: An experimental study of a primitive calc-alkaline basalt from St. Vincent, Lesser Antilles arc. Geochim Cosmochim Acta 66(12):2193-2209

Plank T, Kelley KA, Zimmer MM, Hauri EH, Wallace PJ (2013) Why do mafic arc magmas contain similar to $4 \mathrm{wt} \%$ water on average? Earth Planet Sci Lett 364:168-179

Pownceby MI, O'Neill HSC (1994) Thermodynamic data from redox reactions at high-temperatures. IV Calibration of the $\mathrm{Re}-\mathrm{ReO} 2$ oxygen buffer from EMF and $\mathrm{NiO}+\mathrm{Ni}-\mathrm{Pd}$ redox sensor measurements. Contrib Mineral Petrol 118(2):130-137

Price RC, Smith IEM, Stewart RB, Gamble JA, Gruender K, Maas $R$ (2016) High-K andesite petrogenesis and crustal evolution: evidence from mafic and ultramafic xenoliths, Egmont Volcano (Mt. Taranaki) and comparisons with Ruapehu Volcano, North Island, New Zealand. Geochim Cosmochim Acta 185:328-357. https://doi.org/10.1016/j.gca.2015.12.009

Prouteau G, Scaillet B, Pichavant M, Maury R (2001) Evidence for mantle metasomatism by hydrous silicic melts derived from subducted oceanic crust. Nature 410(6825):197-200

Putirka KD (2005) Igneous thermometers and barometers based on plagioclase + liquid equilibria: tests of some existing models and new calibrations. Am Mineral 90(2-3):336-346. https://doi. org/10.2138/am.2005.1449

Putirka KD (2008) Thermometers and barometers for volcanic systems. Rev Mineral Geochem 69(1):61-120

Putirka K (2016) Special collection: rates and depths of magma ascent on Earth: Amphibole thermometers and barometers for igneous systems and some implications for eruption mechanisms of felsic magmas at arc volcanoes. Am Mineral 101(4):841-858 
Rapp RP, Watson EB (1995) Dehydration melting of metabasalt at 8-32 kbar-implications for continental growth and crust-mantle recycling. J Petrol 36(4):891-931

Reubi O, Blundy J (2009) A dearth of intermediate melts at subduction zone volcanoes and the petrogenesis of arc andesites. Nature 461:1269-1273

Scaillet B, Pichavant M, Roux J (1995) Experimental crystallization of leucogranite magmas. J Petrol 36:663-705

Shejwalkar A, Coogan LA (2013) Experimental calibration of the roles of temperature and composition in the Ca-in-olivine geothermometer at 0.1 MPa. Lithos 177:54-60. https://doi.org/10.1016/j. lithos.2013.06.013

Sisson TW, Grove TL (1993a) Temperatures and $\mathrm{H}_{2} \mathrm{O}$ contents of low$\mathrm{MgO}$ high-alumina basalts. Contrib Mineral Petrol 113:167-184

Sisson TW, Grove TL (1993b) Experimental investigations of the role of $\mathrm{H}_{2} \mathrm{O}$ in calc-alkaline differentiation and subduction zone magmatism. Contrib Mineral Petrol 113:143-166

Sisson TW, Ratajeski K, Hankins WB, Glazner AF (2005) Voluminous granitic magmas from common basaltic sources. Contrib Mineral Petrol 148:635-661

Smith DJ (2014) Clinopyroxene precursors to amphibole sponge in arc crust. Nature Commun 5:4329. https://doi.org/10.1038/ ncomms5329

Stamper CC, Blundy JD, Arculus RJ, Melekhova E (2014) Petrology of plutonic xenoliths and volcanic rocks from Grenada, Lesser Antilles. J Petrol 55(7):1353-1387. https://doi.org/10.1093/ petrology/egu027

Streckeisen (1976) To each plutonic rock its proper name. In: EarthScience Reviews, vol 12. Elsevier Scientific Publishing Company, Amsterdam, pp 1-33

Tollan PME, Bindeman I, Blundy JD (2012) Cumulate xenoliths from St. Vincent, Lesser Antilles Island Arc: a window into upper crustal differentiation of mantle-derived basalts. Contrib Mineral Petrol 163:189-208
Toothill J, Williams CA, Macdonald R, Turner SP, Rogers NW, Hawkesworth CJ, Jerram DA, Ottley CJ, Tindle AG (2007) A complex petrogenesis for an arc magmatic suite, St Kitts, Lesser Antilles. J Petrol 48(1):3-42

Turner S, Hawkesworth C, vanCalsteren P, Heath E, Macdonald R, Black S (1996) U-series isotopes and destructive plate margin magma genesis in the Lesser Antilles. Earth Planet Sci Lett 142(1-2):191-207

Wager LR, Brown GM, Wadsworth WJ (1960) Types of igneous cumulates. J Petrol 1(1):73-85

Wells PRA (1977) Pyroxene thermometry in simple and complex systems. Contrib Mineral Petrol 62(2):129-139

Westercamp D, Mervoyer B (1976) Les séries volcaniques de la Martinique et de la Guadeloupe (FWI). Bulletin du Bureau de Recherches Géologiques et Minières Section IV 4:229-242

Winther KT (1990) Experimental melting of basalt under high $\mathrm{H}_{2} \mathrm{O}$ and $\mathrm{CO}_{2}$ pressures. $\mathrm{PhD}$ thesis, University of Chicago, Chicago, $\mathrm{p}$ 266

Wood BJ, Banno S (1973) Garnet-orthopyroxene and orthopyroxeneclinopyroxene relationships in simple and complex systems. Contrib Mineral Petrol 42(2):109-124

Yamamoto M, Kagami H, Narita A, Maruyama T, Kondo A, Abe S, Takeda R (2013) Sr and Nd isotopic compositions of mafic xenoliths and volcanic rocks from the Oga Peninsula, Northeast Japan Arc: genetic relationship between lower crust and arc magmas. Lithos 162-163:88-106

Yoder HS, Tilley CE (1962) Origin of basalt magmas: an experimental study of natural and synthetic rock systems. J Petrol 3(3):342-532

Ziberna L, Green ECR, Blundy JD (2017) Multiple-reaction geobarometry for olivine-bearing igneous rocks. Am Mineral. https://doi. org/10.2138/am-2017-6154 